
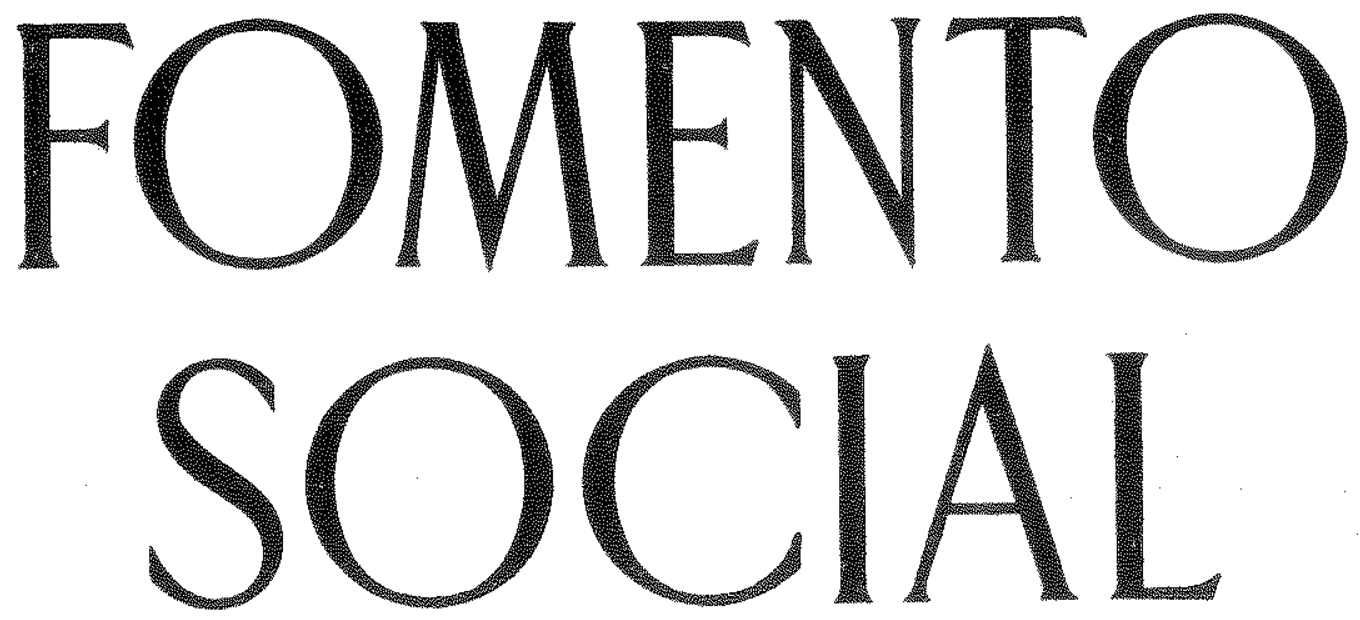

REVISTA DE SOCIOLOGIA Y DE MORAL ECONOMICA

VOL. XII. NUM. 46

ABRIL - JUNIO

1957

MADRID 


\section{SUMARIO}

\section{EDITORIALES}

Consigna de los Metropolitanos. Pág. 131

¿Supresión del salariado?

Pảg. 134

\section{ARTICULOS}

Tendencias actuales de la investigación sociológica, por Antonio Perpiñá Rodriguez Pág. 139

Perspectivas actuales de las migraciones, por Marrtin Brugarola, $S . J$.

Pág. 149

Misión de las asociaciones cristianas de trabajadores, por Luis Antonio Sobreroca, S. J. Pág. 159

Formación de dirigentes sindicales en EE. UU., por Mauro Barrenechea, S. J.

Pág. 177

CARTAS A LA REVISTA

Pág. 191

ESTADISTICAS SELECTAS

Pág. 195

CRONICAS

Pág. 199

REVISTA DE REVISTAS

Pág. 227

BIBLIOGRAFIA

Pág, 235 


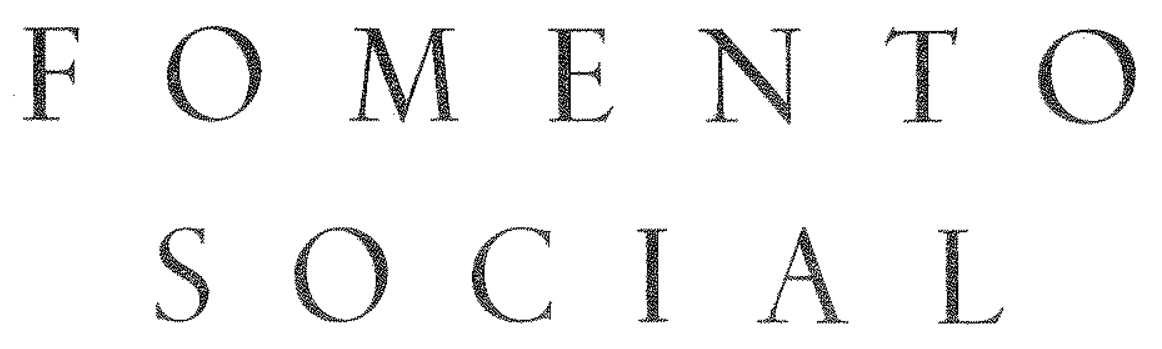

REVISTA TRIMESTRAL DE SOCIOLOGIA $Y$ DE MORAL ECONOMICA

VOL. XII NUM. $4^{6}$

ABRIL - JUNIO

1957

MADRID 


\section{$S U M A R I O$}

\section{EDITORIAXES:}

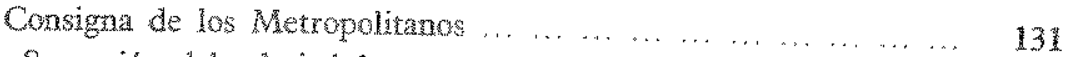

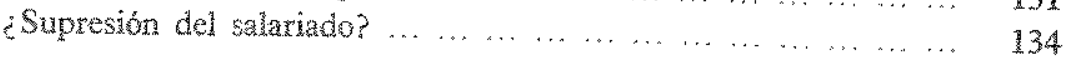

ARTCULOS:

Tendencias actuales de la investigación sociologica, Antonio Per piñá Rodríguez

Perspectivas actuales de las migraciones, Morth Brugorota, S. F. 149

Mistón de las asociaciones cristianas de trabajadores, Luts Antonio Sobreroca, S. $\mathrm{F}$.

Formacion de dirigentes sindicales en EE, UU, Mawro Burrenechea, S. F.

CARTAS A LA REVISTA $\ldots \begin{array}{llllllllllllllllll} & \ldots & \ldots & \ldots & \ldots & \ldots & \ldots & \ldots & \ldots & \ldots & \ldots & \ldots & \ldots & \ldots & 191\end{array}$

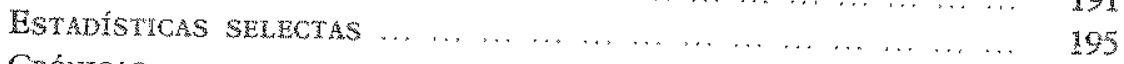

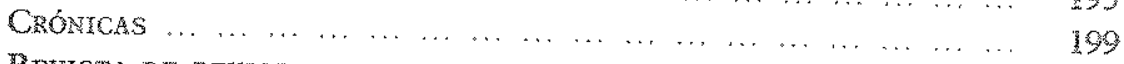

REVISTA DE REVISTAS $\ldots \begin{array}{lllllllllllllllll} & \ldots & \ldots & \ldots & \ldots & \ldots & \ldots & \ldots & \ldots & \ldots & \ldots & \ldots & \ldots & \ldots & 227\end{array}$

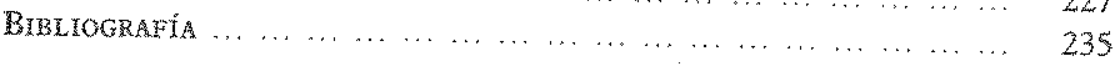

\section{REDACCION DE «FOMENTO SOCLA \\ PABLO ARANDA, 3-TELÉ. 344009-MADERD}

CONSEYO DE REDACCION: PP. Manuel Marina (Director), Florentino del Valle, Martin Brugarola, Agustin Arredondo, Vicente Segarra, D. Angel Torres (Abogado

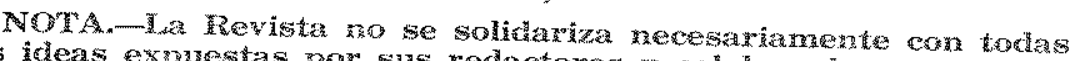
las ideas expuestas por sus redractores y colvobratores, que con la firma asumen la responsabilikad de stis escritos.

$$
\begin{aligned}
& \text { ADMINISTRACION DE «FOMENTO SOCIAL》 } \\
& \text { EDICIONES FAX.-CALLE DE ZURBANO, 80.-APARTADO } 8.001 \\
& \text { TELÉ. } 344291 \text {-M-MADID }
\end{aligned}
$$

SUSCRIPCKÓN.-Precios para 1957 :

España

Para los demás pafses $\ldots$

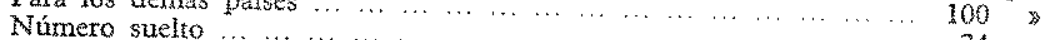

Número atrasado

$\begin{array}{lllllll} & 28\end{array}$

Suscripción de favor, voluntaria $\ldots \ldots \begin{array}{llllllllllll} & \ldots & \ldots & \ldots & \ldots & \ldots & \ldots & \ldots & \ldots & \ldots & 125 & \text { » }\end{array}$ 


\section{EDITORIALES}

\section{CONSIGNA DE LOS ME T R O P O L I T A NOS}

Nuestros Reverendísimos Metropolitanos, como Funta Suprema de la Acción Católica, acordaron, en su ulltima reunión, dar a ésta como consigna para el próximo bienio "Los Deberes Sociales de los Católicos". De tal manera han refrendado con su autoridad colectiva la máxima preocupación que sobre el mismo tema habian ya manifestado otros insignes Prelados y persistido en la misma linea de apostolado de la Declaración de quince de agosto.

Tal vez a algunos parezca ya obsesionante y excesiva esta insistencia en lo social, pero la resolución de los Metropolitanos, aparte su autoridad excepcional, no hace sino responder a la realidad objetiva de la sociedad contemporánea, en plena efervescencia y evolución.

Bastarian dos hechos, mensurables, tangibles, para justificar a priori esa importancia de lo social. De una parte el crecimiento formidable de la población en el mundo que nos obliga constantemente a revisar los espacios vitales y su distribución. De otra, el desenvolvimiento más formidable de la técnica. Pero es que sobre esas dos lineas ascensionales constantes, se cruzan y entrecruzan otras mil, que forman como el cañamazo sobre el que va dibujando la libertad humana el enmarañado tejido de la sociedad contemporánea.

Los católicos, apoyados sobre el fundamento de esas verdades absolutas, cuyo valor ha vindicado el Papa en su Mensaje de Navidad, somos los únicos que podemos asistir con 
relativa serenidad, tanto como espectadores cuanto como protagonistas, al desarrollo del drama, superando la contradicción y la angustia en que se debaten tantos otros.

Con relativa serenidad, hemos dicho, porque no excluimos, como humanos, la posibilidad de la vacilación y el temor transitorios; pero con serenidad, al fin, habitual y verdadera, cual corresponde al que cree que nada debe turbarle porque "Dios no se muda" y "solo Dios basta". Y somos "únicos" en nuestra privilegiada posición, porque annque la verdad fundamental de Dios y su Providencia sea compartida por otros, pero no con aquella certidumbre y perfección que le da la revelación cristiana y que alcanza su ápice con el dogma del Primado de Pedro y sus sucesores y el atributo de la infalibilidad Pontificia.

Lejos, pues, de extrañamos la insistencia con que el magisterio vivo de la Iglesia nos llama al cumplimiento de nuestros deberes sociales, hemos de ver en ello una confirmación de su misión excelsa, adaptada a las necesidades de la hora presente.

$Y$ notemos, para deshacer el equívoco de muchos, que la doctrina social católica no es en modo alguno socializante, como no es liberalizante y capitalista, ni mezcla arbitraria de todas. Tiene toda la sustantividad y originalidad que le confieren sus fuentes nativas: la verdad, que fluye a través de la razón como ley natural participada de la ley eterna, y a través de la revelación como palabra de Dios.

Así, la doctrina social católica, que no viene a ser en muestros dias sino "el cristianismo socialmente aplicado", como ha dicho el $P$. Lombardi, puede ofrecer sus maravillosas soluciones armónicas, no por vía de componendas y regateos, sino por el auténtico realismo de su verdad perenne y perennemente adaptada.

Bastará al lector recorrer la breve crónica que del Magisterio Eclesiástico hacemos en este número para convencerse del abismo que separa su doctrina social de las tendencias masificadoras del comunismo. Diriase que el Papa vive con la obsesión de vindicar ante todo los valores inalienables de la persona individual, para asentar sobre ellos, sólidamente y en sentido legítimo, las debidas estructuras sociales. Pero estructuras vi- 
vas, alentadas por el espíritu, no a la manera de agregaciones mecánicas; estructuras históricas, dotadas de continuidad, no meros engendros apriorísticos; familia, propiedad, municipio, Estado... no como instituciones muertas y superadas sino como formas permanentes de vida social, aunque abiertas siempre a la superior integración y al progreso, en el admirable coniunto orgánico de la universal sociedad humana.

Pero no podemos proseguir en estas consideraciones doctrinales ni queremos dejar de hacer algunas considenaciones práticas.

Nos parece que las ardientes palabras de Pio XII, al prom clamar el diez de jebrero de 1952 la Cruzada por el Mundo Mejor, tienen ahora singular aplicación a mestra patria. Llevamos ya bastantes años de formación de conciencia social, de cultivos selectos, de estudios y publicaciones doctrinales. Claro es que esto debe proseguirse e intensificarse, en "ejercicios espirituales", "ejercitaciones" lombardianas, "cursillos de cristiandad", "semanas de la HOAC", círculos de estudios, conferencias, misiones, etc., etc.; pero no nos olvidemos de aquellas decisivas consignas del Papa exhortando más todavía a la ejecución, a las obras. Son estas consignas las que deben pesar de un modo decisivo en este bienio y llevarnos por la superación y la coordinación de tantos y tantos movimientos aislados y de guerrillas a dar forma grandiosa y pujanza arrolladora al gran movimiento social cristiano que España necesita y puede crear. "Ha llegado ya el tiempo - dice Pio XII- de realizar los pasos definitivos... Manos pues a la obra; muévaos Dios, que esto quiere; que os atraiga la grandeza de la empresa, que os estimule su urgencia; el justificado temor del porvenir terrible, que se derivaria de una culpable inercia, venza todo titubeo y afiance todas las voluntades." 


\section{¿SUPRESION DEL SALARIADO?}

En la sección "Cartas a la Revista" podrán ver mestros lectores una del P. fosé María Azpiazu en que expone su juicio, en parte adverso, respecto del artículo del P. Díez Alegria, "El Salario ante la Filosofía del Derecho", publicado en nuestro número anterior.

Suponemos que muestros lectores, lejos de maravillarse de esta diversidad de apreciaciones en materias tan complejas, agradecerán la oportunidad que se les ofrece de considerar desde distintos puntos de vista un problema de tanta trascendencia $y$ actualidad. Por algo imprimimos habitualmente en una de las primeras páginas esa nota, que no es en modo alguno formularia sino expresiva de una mesurada libertad de criterio: "La revista no se solidariza necesariamente con todas las ideas expuestas por sus redactores y colaboradores, que con la firma asumen la responsabilidad de sus escritos".

Sin arrogarnos autoridad para dirimir las diferencias entre tan doctos profesores (aunque no quisiéramos desde luego dar cabida a una insistente polémica) nos parecen oportunas algunas consideraciones.

El artículo del P. Díez Alegría es verdaderamente propio de un profesor de Filosofía del Derecho. Nadie le negará profundidad ni alcance. $Y$ aunque suponemos que aun desde el punto de vista filosófico-jurídico no todos estarán conformes en el punto crucial del raciocinio que le lleva del hecho de la comunidad natural del trabajo al "derecho en justicia conmutativa -de los trabajadores- a participar de los beneficios comunes", habrá de reconocerse la luminosidad de sus ideas que proyectan la luz hasta lejanas consecuencias en el mundo de la Sociología y del Derecho. 
El P. Azpiazu, en quien se esconde el antiguo profesor de Teologí, reacciona más bien aquí (sin exchir razones teóricas) como sociólogo práctico y apóstol social, que encuentra más hacedera y prudente la reforma del salariado conforme a la doctrina insistentemente inculcada por los Papas, que lanzarse a la avenura de una implantación legal y casi universal del régimen de sociedad con menosprecio de las posíbilidades prácticas y de justo contenido del régimen de salario.

Doctrina de la Iglesia y prudencia reformadora; he aquí dos conceptos que importa subrayar.

Hemos de ponernos en guardia contra una posible subestimación de la doctrina social católica positiva, tal como enana concretanente al fluir de las circunstancias de lugar y de tiempo. En ese flujo del magisterio wivo y jerárquico de la Iglesia tenemos los católicos la mayor garantia de acierto, frente a la inmovilidad de los textos escritos petrificados y a la arbitrariedad de un exagerado subjetivismo. Y que esa subestimación, tan palpable y desgraciada en las aplicaciones prácicas, pueda pasar a ser también teórica en los medios intelectuales cristianos es un peligro que venimos adviriendo por crecientes indicios.

Respecto del salario tenemos enseñanzas terminantes en los documentos de la Ferarquía eclesiástica. Conocida es la afimación básica de Pio XI en el número 29 de la Quadragesimo Anno:

«Los que condenan el contrato de trabajo como injusto por naturaleza, y dicen que, por esa razón, hay que sustituirlo por el contrato de sociedad, hablan un lenguaje insostenible e injurian gravemente a Nuestro Predecesor, cuya Enciclica (Rerum Novarum) no sólo admite el salario, sino aún se extiende largamente explieando las normas de justicia que han de regirlo.»

$Y$ junto a esta afirmación categónica se formulan con estudiada mesura las aspiraciones al contrato de sociedad.

«Pero juzgamos que, atendidas las condiciones modernas de la asociación humana, sería más oportuno que el contrato de trabajo algín tanto se suavizara en cuanto fuese posible por medio del contrato de sociedad, como ya se ha comenzado a hacer en diversas formas con provecho no escaso de los mismos obreros y aun patronos. De esta suerte los obreros 
y empleados participan en cierta manera, yo en el dominio, ya en la gestion de la empresa, ya en las ganancias obtenidas.”

Pio XII, lejos de sobrepasar las afirmaciones de su predecesor, ha puesto empeño en que no quedaran desbordadas la eficacia de la empresa y la razonable autoridad y responsabilidad del empresario por una precipitada imupción en el mando de los productores subordinados, sin suficiente preparación para ello. Nos limitamos a una sola cita entre las numerosas que podrínos espigar de sus discursos.

* Se habla hoy mucho (decía el 31 de enero de 1952 al Consejo Nacionat de Empresarios Católicos de Italia) de una reforma en la estructura de la empresa, y quienes la promueven piensan, en primer lugar, en modificaciones juridicas entre todos cuantos son sus miembros, ya sean empresarios, ya dependientes incopporados a la empresa. No escapan, sin umbargo, a Nuestra consideración las varias tendencias que en tales movimientos se infiltran, las cuales no aplican - como conviene- las incontestables normas del derecho natural a las mudables condiciones del tiempo, sino que simplemente las excluyen. Por esto en Nuestros discursos del 7 de mayo de 1949 a la Unión Internacional de las Asociaciones Patronales Católicas y del 3 de junio de 1950 al Congreso Internacional de Estudios Sociales, Nos Nos hemos opuesto a esas tendencias, no ya, en verdad, para favorecer los intereses materiales de un grupo más que los de otro, sino para asegurar la sinceridad y la iranquilidad de conciencia a todos aquellos a quienes atañen estos problemas.'

La Declaración colectiva de los Metropolitanos Españoles, de 15 de agosto pasado, constituye finalmente para nosotros la mejor garantía de actualidad y adaptación a nuestra patria de la doctrina general expuesta por los Papas. En ella se habla largamente de las condiciones del justo salario; todo indica en la misma que se presupone no sólo la justicia fundamental de ese régimen, sino la creencia de que ha de perdurar, y aun seguir dominando, por tiempo indefinido. Al tratar luego de la evolución hacia el régimen de sociedad, imitan nuestros Metropolitanos la mesura de Pío XI. "La Iglesia —nos dicenve con buenos ojos y aun fomenta todo aquello que, dentro de lo que permiten las circunstancias, tiende a introducir elementos del contrato de sociedad en el contrato de trabajo y mejorar la condición general del trabajador." 
Si de la doctrina de la Iglesia pasamos a la consideración de las circunstancias económicas, técnicas y humanas en que se desenvuelve nuestro mundo del trabajo, para una estimación prudencial de lo que puede y debe ser, hic et nunc, en orden a satisfacer del mejor modo los imperativos de la justicia y nuestros vehemente deseos de superación del proletariado, hemos de confesar, por más que nos seduzca como más perfecta la estructura social de la empresa - tanto más cuanto mayor sea la compenetración en ella de todos sus elementos constitutivos-, que no juzgamos factible una pronta y general abolición del salariado en nuestra Patria. No es que se haya de interrumpir el esfuerzo para superarlo; no es siquiera que no hayamos de acelerar todo lo posible el ritmo para lograr tal superación; sino que esa marcha debe ser constructiva y segura; con un ritmo tan veloz como pueda lograrse, pero dentro siempre del equilibrio entre los posibles cambios de estructura y la elevación cultural de los productores, entre lo vital y lo orgánico, la legalidad y la espontaneidad, lo estatal y lo social; sin dejar nunca de profligar los abusos de poder del capitalismo, pero sin erigir en deberes ciertos de justicia otras exigencias que no merecen tan imperiosa calificación. De otra suerte (como una experiencia en que España es más rica por haber sido más escarmentada nos enseña) podríamos correr el riesgo de estrellarnos al querer saltar etapas que es preciso superar penosamente con tesonero empeño. 


\section{ARTICULOS}

\section{TENDENCIAS ACTUALES DE LA INVESTIGACION SOCIOLOGICA}

\section{La pugna entre "Teoría" e "Investigación"}

Symagzio: Las tres naciones que han dado wh itruto soctológico solection: Alemathia, Francia y Estados Unidos,--Pueden, sin embargo, aghutarse en dos iendencias: la germanofrances y la de Zstados Unidos,-La corriente eurapea, hás orientada a la construcción de sistemas y de ideas generales, "Leorias, y la carrienta nonteamericana, orientada a descabrimanto de sinuaciones y problemas pantianla res y concretos, winvestigación》.--La «investigación》 tiende a desplazar a la «teom rà incluso de Europa; contra lo que ha sucedido otras weces en la Historia, ahora «victores victis leges dant».-Predominio en América del empirismo; preferencia casi exchusiva a las llamadas utécnicas de investigucionn, a la Social Research. Tamm bién en el instante actual lo que más influye sobre Europa es el empirismo enragé; se puede hablar de una auténtica marshalización de la Sociologia auropea.-La tendencia a sustituir la teoria por la investigacion no es un simple cambio de enfogue, sino un atentado a muerte contra toda ciencia social. La misión de una ciencia sociológica no es mostrar la individualidad transitoria de un proceso social, sino proveemos de los principios generales que permitan dominar ese hecho de una manera racional. Se explica la relación entre teoría e inwestigacion con el ejemplo de la medicina; se está volvizndo a una especie de ucuranderismos socio. logico.--Intento de explicación de estas actitudes.-.-El clamor por lo concreto, refugio contra el desengaño ante lo abstracto; el cansancio filosófico de Europa y la admirción o adulación al vencedor.-Conclusiones: 1) la winvestigacions tiene su walor, pero no se ha de sobrevalorizar; 2) la sinzuestigación» no puede sustitusir a la uteoría»; 3) la ciencia sociológica ha de ser ecléctica: combinación prudente de teoria e investigacion; 4) hay algo que revatoriza la uilidad de la investigacion, pero más alla del recine de la ciencia: su gran importancia para la zida prácticaDesgraciadamente, esta sencilla postura ecléctica no está suficientemente recogida por las tendencias actuales de la investigación sociologica, pero debería serlo.

Cualquier intento de ordenación sistemática de los diferentes esfuerzos que se han hecho desde hace un siglo por crear y desarrollar una ciencia sociológica, no puede en modo alguno prescindir del aspecto nacional. Los cuadros de clasificación de las escuelas con arreglo a su inspiración filosófica o estrictamente teórica (Sociología biológica, mecanicista, histórica, etc.) resultan, a pesar de su aparente justificación lógica, tan insatisfactorios y aún más que los de distribución geográfica y política de las doctrinas (So- 
ciología alemana, francesa, etc.). Por lo menos este bultimo criterio tiene la ventaja de reducir al mínimo la arbitrariedad o el error en la ubicación de autores. $Y$ dentro de este espiritu de sistematización puede asegurarse que, propiamente, hasta ahora sólo ha habido tres naciones que hayan dado ura fruto saciológico colectivo digno de mención: Alemania, Francia y Estados Unidos. En los demás países lo único que puede comprobarse es una influencia mayor o menor de esas tres fuentes de inspiración sociológica y el esfuerzo aislado de algunos pocos pensadores, verdaderos francotiradores

Dentro de aquellas tres grandes naciones, y pese a que entre Alemania
Francia pueden encontrarse diferoncias no y Francia pueden encontrarse diferencias notables, todavia puede apurarse más la sintesis clasificatoria oponiendo pura y simplemente la Sociología europea y la americana (norteamericana). Aunque Sombart haya opuesto el pezaba aquende el Rhin), lo cierto es que la ciencia el uOccidente» enacerca bastante más a la germana es que la ciencia sociológica francesa se cialmente en torno del pensamiento a la norteamericana. Centrada sustantonas supo descubrit Simón Deploige Enilio Durkheim, cuyas raíces teuliar de la especulación europea: la teoría abstracta y sisteme el sello pecuxión inescindible con la Filosofia : Mas como existe sintemática, en coneceres en reconocer la presencia de estos caracteres en las doctidad de parey como, por otra parte, hay la misma coincidencia las doctrinas alemanas, sajonas los caracteres opuestos de empirismo, pragmatismo atribuir a las anglolo concreto, podemos resumir nuestro punto pragmatismo e inclinación por ahora por lo menos, la Sociologí ha punto de partida diciendo que, hasta acuscdas: hacia la construcción ha adoptado dos tendencias generales bien europea) y hacia el descubrion de sistemas y de ideas generales (corriente y concretos (corriente norteamento de situaciones y problemas particulares las palabras designa lo primero cona). Un uso seguramente convencional de ción. $\mathrm{Y}$ se pregunta ahora cú́ como teoría y lo segundo como investiga corrientes en la actual coyrungur es la posición absoluta y relativa de estas de su carrera.

Para precisarlo en forma expresiva nos vamos a permitir una brevísima digresión. Comentando Séneca la influencia que los judios ejercieron, a pesar de haber sido vencidos, sobre las costumbres y métodos de vida de hubieran dado leyes a los veno destacar la paradoja de que los vencidos lidad, este fenómeno de penetración : victi victoribus leges dedere. En realítica y militarmente vencidos en el o invasión cultural de los pueblos pode espiritualidad, no se dió sólo en ese de los vencedores de inferior grado

1 Podríamos traer aquí citas de Roger Lacombe, Luigi Sturzo, Jacques Leclerq y Georges Gurtich, por lo menos, demostrando cómo la doctrina de Durkheim
remata en una clara posición filosófica, de Conzte y Hegel. posición filosófica, metafísica y aun teológica, muy afín a la 
una ley historica general (otros ejemplos mucho más significativos se dieron en el trinfo espiritual de Crecia sobre Foma y en el de China sobre los mogoles). Ahora bien: la situacion cultural subsiguiente a la guerra de 1939-1945 ba de ser planteada y valorada con cuidado. Dejando ararte el mundo soviético, cuya ciencia sociológica se desenvuelve autónomamente, sin conextones ni influencias con el mundo occidental, y acudiendo a las tres naciones rectoras de nuestra disciplina, dese luego podenos wbicar a 10 Estados Unidos de América entre los vencedores y a Alemania entre los vencidos. $t Y$ Francia Técntcamente, deberwa entrat, sin guda, entre los vencedores; pero si comparamos su situacion polfrica anates y después de la segunda guerra mundial, y persamos que post bellam sólo han quedado dos auténticas grandes potencias, no seráa exagerado atirmar que desde un pinto de wista amplio y general ha derrotada en la guerra no ha sido Alemania, sino Europa cono wnidad.. con la twisma unidad gye le atriburmos al hacer el balance del moviniento sociológico: Y, aplicando el esquena de Séneca y de esos otros ejemplos históricos, podramos preguntar si tambien ahora se ha cumplido la misma ley sobre relación reciproca cultural entre el vencem dor norteamericano y la vencida Europa.

A nuestro juicio, lo curioso del fenómeno es que ahora se ban invertido los términos, y han sido los vencedores políticos los que, a despecho de traer un acervo cultural inferior, están imponiendo a los vencidos sus propias normas de pensar, sus peculiares pattems of culture teóricos: Victores victis leges dant. Lo que trasladado al terreno de las rendencias sociológicas quiem re decir que la uinvestigación tiende a desplazar a la steoría incluso de Europa. El fenómeno tiene mucha mayor gravedad de lo que suele creerse, ya que no implica un simple cambio de perspectiva en la concepción de la ciencia social, sino más bien una sentencia de muerte contra la misna.

Si todo se redujera al deseo de vivificar acartonados sistemas especulativos con savia refrescante de la observación inmediata de los hechos; $a_{3}$ más exactamente, si todo consistiera en el reconocimiento del doble axioma de que: a) la elaboración de conceptos abstractos debe ir constantemente acompañada de la inspección directa de los hechos concretos sometidos a conceptuación; y b) esta inspección ha de estar rigurosamente controlada mediante técnicas precisas; entonces, decimos, no habría nada que oponer al fenómeno de recepción antes reseñado. Teoría e investigación marcharían de acuerdo, y cualquier polémica en tomo de las mismas quedaría confinada en los detalles secundarios. En realidad, esto es lo que piensan y dicen los autores más sensatos y ponderados de ambos lados del Atlántico; pero no es eso lo que constituye el núcleo principal de la corriente de influencia que invade el viejo Continente. Y que sea asi depende de una doble razón. En primer lugar, en el pais de origen tiene más peso efectivo la opinión que condena y rechaza la teoría que la que estima que debe colaborar con la investigación; 0 , por lo menos, priva destacadamente el partido de los que 
colocan la segunda por encima de la primera. En segundo término, en el ámbito cultural de destino los autores inclinan la balanza más atún en esa dirección.

1. Cualquiera que se asome al panorama de la literatura sociologica notreamericana, echatá de ver en seguida el predominio que allí tiene el empirismo como crudo examen de lo concreto. Sus revistas especializadas abundan considerablemente en «trabajos de investigación» sobre situaciones - hechos concretos y singulares, y son pocos los artículos que se dedican a exponet «teorías》 desligadas del hic et nunc. Incluse cuande los sociólogos no tienen más remedio que hacer teoría -en los libros de texto y enseñazza- muestran especial preocupación por insertar gráficos, estadisticas, descripciones de sucesos singulares, etc., cono si, por ejemplo, to de menos fuera dar el concepto genérico del divorcio y su significacion sociocultural, siendo lo thás importante que los alumnos sepan el támero de man trimonios disueltos a principios de siglo en el Japór. Finalmente, cuando en ese gran país se elabora una obra de metodología se hace referencia casi exclusivamente a las llamadas «técricas de inyestigación», a la Social Research, como si el único "camino» de la ciencia fuera el que conduce al análisis de datos concretos y no al descubrimiento de nociones y leyes generales. Es muy cierto que no faltan alli voces de protesta. En la American Sociological Review y en The American foumal of Sociology hemos encontrado muy interesantes articulos de Robert Bierstedt, Th. Abel, Robert Redfield, T. Parsons, R. K. Merton, etc., rompiendo lanzas en pro de la teoría; conocemos también algunas de las obras de los últimamente citados, en el mismo sentido, y hemos saboreado los magnificos textos de $F$. Znaniecki, P. A. Sorokin y P. H. Furfey sobre verdadera «teoria» y metodología sociológica. Pero seguramente estas voces, pese a su autoridad, son de las que claman en el desierto... aparte de que no faltan tampoco en algunos de esos mismos autores ciertos deslices que demuestran cómo el empirismo, verdadero morbus theoreticus anglosaxonum, es algo casi consustancial con el pensamiento de esa área cultural (así, la repulsa de los «sistemas» o «teoría general» por pensadores de la talla de un $\mathrm{H}$. E. Bames o un $\mathrm{R} . \mathbb{K}$. Merton),

2. Es posible que, como entienden algunos, se esté produciendo en al nuevo Continente una saludable reacción antiempirista; no queda fuera de lo verosimil, incluso, que a la larga el espiritu de los vencedores americanos se deje seducir por la cultura europea, y con ello acepte los supuestos del racionalismo teórico; pero no es menos cierto que, en todo caso, en el instante actual to que más influye sobre Europa es el empirismo enragé. También aquí sería de citar una ley según la cual lo que más se inita y recibe son las posturas extremas. Sólo así puede tener sentido que en naciones tan empapadas de vieja solera filosófica y cientifica se oigan voces pidiendo una Sociología «de lo concreto», el abandono del gabinete de estudio para adentrarse en el terreno del «trabajo sobre el terrenon... y que incluso autores de la envergadura filosófica y de la sabiduría sociológica de G. Gurvitch. 


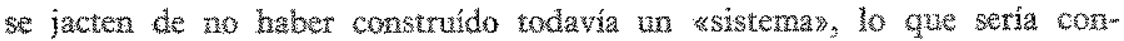
trario al hiperempirismo propio de la ciencia social".

Dn resumen, Buropa presenta al acabar la segunda guera mundil un panorama may parecido al de los Estados Unidos al twmino de la de 1914 m 1918: we tende a abandonar los viejos y estériles sistemas, para entrar con entusiasmo por la va de la juvestigación empínica. Aungue en el Plan Marshat no iba includa la ayuda en ideas sociologicas y metodológicomsociales, la iniciativa privada y oficiosa se desvive por realizar una atentica marshatim zacion de la Sociologia europea. ¿Qué juicio míco debe merecenos esta tentativa?

Muchos comentarios deben hacerse en torno del pleito imvestigación zersus terra; pero, a nuestro jucho, lo primero y principat gue hay gue presentar ante los ojos de los fanáticos de la primera es que, inconscientem mente, al atacar a la segunda combaten aguelo que para ellos es el supremo valor sobre la tierra: la «ciencia». No hay que olvidar que, cu términos generales, los partiàrios furibundos de las técnicas de investigación son adonadores de ese contemporáneo diosecilo que ha venido a sustiuir er veneración y prestigio a Dios de nuestros antepasados (ya Victor Hugo decia que kesto matará aquellon, pensando en el libro y la catedral, respectivamente). Pues biex, si tería y ciencia son términos intercambiables o conceptos equivalentes, todo ataque contra la teoria es una apostasia contra la ciencia. $\mathrm{O}$ dicho de orra manera: la tendencia a sustituir la teoría por la investigación no es un simple cambio de enfoque en la Sociologí, sino un atentado a muerte contra toda ciencia social.

Nació ésta en su forma contemporánea como intento de aplicar a los fenómenos de la vida de relación interhumana los mismos principios y criterios que venian rigiendo desde el Renacimiento para las disciplinas físicom naturales (Comte); $y$ aunque uleriormente en muchos sectores se haya rectificado el naturalismo inicial y en otros se hayan adoptado posturas especiales distintas, creemos que todos los sociologos estarán de acuerdo on admitir que el supuesto y el propósito de su especial tarea es captar la sociedad bajo el prisma de ese conocimiento que se llama ciencia positiva y empiriológica, en parấlo con lo que hacen la Física, la Quírica o la Biología con las parcelas del mundo objetivo que corresponden a su especialidad. Ahora bien: en todas éstas lo que se hace es teoria y no investigación. Su misión es el descubrimiento de fómulas generales de desenvolvimiento

2 No desconocemos que en el gran escritor ruso-frances - como en Hans Freyer y otros, también enamorados de la Sociologia de lo concreto- el supuesto filosófico de ese empirismo no es el pragmatismo naturalista, como en Aunerica, sino el vitalismo en sus diferentes formas; pero en todo caso habrá que reconocer, por lo menos, que la descomposición del espíritu europeo por obra y gracia del irracionalismo ha preparato el terreno para la invasión de las corrientes puramente empiristas. 
de los fenómenos (leyes) o la enunciación de proposiciones que definan con generalidad los hechos y cosas sujetos a nuestra experiencia (conceptos, categorías, tipos); y de ninguna manera el aprehender en su propia, intransmisible e irreproducible singularidad tal proceso o cuál cosa según se dan hic et nunc. Ningún libro de Física - salvo los manualitos de primera enseñanza- trae la temperatura media que hubo el año en que se publicó en 1 a ciudad residencia de su autor; como ningún tratado de Fisiología expresa el promedio de glóbulos rojos de los habitantes de Chicago en 1900 , 1910,1920 , etc. Sin duda, que los físicos y los biólogos han necesitado efectuar comprobaciones e investigaciones de ese tipo; pero no llevan sus tesultados al corpus de su ciencia, ni menos aún pretenden que en ésta las abstracciones y generalizaciones deben ceder el puesto a las exploraciones sobre el terreno, a una Física o una Biología wde lo concreto», a los whechos» mismos de la realidad. Cuando en Sociologia, repetimos, se preconizan esas innovaciones, lo único que se hace es pedir la renuncia o el abandono de la ciencia social. Porque si ya toda ciencia, por setlo, es conocimiento abstractivo y general (en cuanto basado en conceptos racionales y no en intuiciones inmediatas concretas), la Sociología además, como ciencia "generalizadora», no podrá en modo alguno pasarse sin todos esos mecanismos del pensaraiento racional que se combaten o menosprecian por el empirismo investigador.

Sería triste que la vieja Europa, pletórica de experiencia y sabiduría filosófica, no fuera capaz de descubrir el trasfondo epistemológico de esa glorificación de la Social Research. Una impresión somera podría conformarse con ver ahí una postura pragmatista, que antepone el vivere al phim losophari y que asigna a la teoria, como único fin lícito y comprensible, la acción sobre las cosas y asuntos de la vida. No. Esa postura es perfectamente legítima dentro de una Epistemología severa, ya que respeta los fueros propios del pensamiento cientifico racional y separa, comm'il faut, pensar y vivir, teoría y práctica - su tesis será discutible en la Teoría de los valores como teoría de la vida, mas no en una Teoría del conocimiento-. Lo que subyace en las doctrinas que aspiran a invadir el Viejo Continente es algo más radical: primero, el desprecio de la especulación ea sí, y segundo, su menosprecio como instrumento para la acción. Esto último es justamente lo que implica una flagrante contradicción con la fe positivista en la eficacia de la razón natural, o sea, una desviación sustancial de los métodos y espíritus de las ciencias naturales, que los autores en cuestión dicen servir lealmente.

Es indudable que la aplicación de la ciencia física supone tanto como acudir a los objetos materiales concretos para operar sobre ellos... Pero la misión de la ciencia física no es enseñar a conocer esos objetos tal como son en su materialidad "concreta», sino enseñar ideas y leyes «generales» que nos hagan aptos para manipularlos y transformarlos de modo racional. Paralelamente, la misión de una ciencia sociológica propiamente dicha no será mostrarnos la individualidad transitoria y eventual de éste o el otro proceso o grupo social, sino proveernos de los principios y teoremas genera- 
Les que nos permitar afrontar y dominar ese hecho de una manexa ractonal. Pero eso es uteorià y nada más. Si la Lógica: fuera solamente una keonfa de la investigación como cree John Dewey; si in ciencia consiscera, no en un cúmulo de conocimientos generalss sobre tenómenos, sine en el método para la aceptacibo de situaciones concretas, segun entienden esos utraprag matistas; entonces, decimos, habria que enterrar eso gue hesde los griegos viene lamándose pensamiento cientifico, teorí, etc.

Para comprender bien la relación entre kteoria» \& «nvestigación» nada más aleccionador que meditar en el paralelo que se da en el campo de la Medicina. En cuanto ésta se ha configurado como ciencia, esta constituida por una serie de conocimientos de caráctar general y abstracto-puncipios y leyes de la Fisiología, la Patología y la Terepética- apleables a un mumero indefindo de casos. Esos principios y leyes han sido obteniabs por 1a observación y el expermento controlados, por la meditacion siscemática y racional y por aplicación de los obtenidos en otras ramas del saber (Ou mica y Biologíg, sobre todo). Por wo ello, constituyen un genuino saber cientifico. Evidentemente, la Medicina es ciencia práctica de aplicación $y$, por lo mismo, necesitaráa aplicar sus supuestos generales según las exigencias de cada caso singular, de cada entermo, teniendo para ello que habiLitar las correspondientes técnicas de exploracion, ausculracion, análisis, etc. Pero a ningún médico se le ocurriría decir que el núcleo de su ciencia esta constituido por las reglas técnicas de auscultación, etc. Está muy bien que al tratar de sanar a alquien se aquilate lo más posible su exacta situación biológica concreta; pero esto también puede hacerlo un curandero sin dejar de ser un simple empirista o un supersticioso, siempre que después de ese conocimiento de lo concreto se linite a aplicar sus reglas irrazonadas a incontroladas. El ejercicio cintílico de la Medicina no depende primariamente del uso del termómetro, el estetoscopio, el electrocardiógrafo, de los análisis cuantitativos de sangre, etc, sino de que después el médico sepa aplicar al caso concreto asi precisado los principios generales de la teram péutica, que son la verdadera ciencia.

Pues bien, cuando en Sociología se quiere recargar el acento sobre la fase de exploración de las situaciones sociales concretas (inzestigación), desdeñando el descubrimiento de enunciados generales sobre el acaecer social (teoria), lo único que se preconiza es la renuncia al uso de métodos ciertíficos para la reforma social, con vuelta a un retrógrado y antiprogresista «curanderismo». Un curanderismo, además, acaso peor que el practicado por los antiguos gobernantes fiados en su inspiración el postulado por arbitristas irresponsables, ya que éste de ahora se presenta con ropajes ale «cientifico» $y$, por lo mismo, asistido de la autoridad casi dogmática que el espíritu de la época atribuye a lo que así se denomina (aunque no lo sea).

Réstanos ahora por sugerir brevemente un intento de explicación de la actitud «sociologuicida» (permitasenos la expresión) que el desprecio de la 
"teorias social lleva aparejada. A nuestro juicio, en Norteamérica ha operado una doble causa: el fracaso del propósito sociológico contiano de reformat la Sociedad con métodos científicos analogos a los que, desde hace más de un siglo, van llevando al dominio de la Naturaleza; y, en conexión con esto, el espínitu racional, poco propicio a la especulacion y abierto casi exclusivamente al activismo y a la vida externa. Todavia se siguen oyendo voces que aseguran que en el terreno de los problemas sociales y politicos "puede salvarnos la ciencian; pero los que así lo siguen creyendo piensan realmente en la ciencia natural, no en la social. La era atómica no se corresponde precisamente con un robustecimiento proporcional de las ciencias sociales -al menos en cuanto a su eficacia práctica-, y a la vez que crece la admiración por la Fisica, la Química o la Biología, se extiende, en contrapartida, un cierto desprecio por la Sociologia, a que ex vano se quiere ackdir para que suministre leyes fenoménicas que permitan una dirección cientificamente controlada del orden social ${ }^{3}$. El clamor por lo uconcreton es un refugio contra el desengaño ante lo «abstracto».

Más rigurosamente todavía, creetnos ver aquí lo que podríamos calificar de puerilismo compensador. Como el niño que sueña con grandes hazañas bélicas que la realidad le veda y que sustituye por feroces batallas entre sus soldaditos de plomo, de igual suerte el creyente en la eficacia ilimitada de la ciencia no se ha conformado ante el fracaso práctico de la "teoria» social, y en su lugar se viene dedicando a «jugar a la investigación». Porque ¿de qué otra manera pueden calificarse esos enormes despliegues de medios materiales, esos gastos considerables de dólares. y esos ingentes esfuerzos personales para llegar únicamente, como dice P. A. Sorokin, a uuna penosa elaboración de verdades que ya eran evidentes»? Vemos a John A. Watson, el apóstol del behaviorismo psicolégico, preconizando clínicas, casas cunas modelos y demás instituciones grandiosas y costosas para comprobar muy poco más de lo que un modesto padre de familia sabe sobre el «aprendizaje» existencial de los niños. Leemos con asombro en la obra de Roger Ph. Girod (Attitudes collectives et relations humaines. Tendances actuelles des sciences sociales américaines. París, 1953), las magnas encuestas dirigidas por G. Myrdall y S. A. Stauffer sobre «el problema negrow y el ajuste del soldado americano a la vida militar, que han venido a rematar en unas conclusiones que cualquier mediano conocedor del problema racial en Norteamérica y del espiritu de todos los soldados del mundo conocía

3 En realidad, el fracaso ate la ciencia social es solo relativo, pues ya en ella - -sobre todo en la ciencia política y en la económicam hay algunas formulaciones sobre leyes de acaecer bastante aproximadas y precisas. Lo que sucede es que, por muchas razones, esas leyes no se pueden aplicar; o, mejor dicho, hay muchos motivos por los cuales no se sigue la conducta que el enunciado de esas leyes aconsejaría; queremos decir que la aplicación de esas leyes, o las prevenciones para que no se cumpla lo que ellas prevén, es algo que no conviene a los poderosos, los cuales, por lo mismo, impiden el empleo pragmático eficaz de los conocimientos. sociológicos. 
ya por anticipado. Los conocidos udescubrimientos» a que dieron lugar las investigaciones en la Western Electric, sobre relaciones humanas en la industria, habrán sorprendido a los investigadores académicos, pero no cree mos que sean nada nuevo para la mayor parte de los jefes de industria o directores de personal de las grandes empresas... En una palabra, la Sociat Research parece a menudo una especie de refugio pueril en que la fe cientifica trata de consolarse del desengaño que le produce la inseptitud relativa a la teoria social.

Europa no es un aiño grande como los tistados Tnidos de América, sino un viejecillo que cada vez se arruga más; pero si la biología de las edades comprueba un cierto acercamiento en los dos extremos de infancia y vejez, también aquí el espíritu anciano se halla en trance de contagiarse de la puerilidad. Juega aqui asimismo el factor de contemplación del fracaso pragmático de los grandes sistemas sociologicos en un monerto en que la vida reclama angustiosamente soluciones prácticas; de suerte que si Europa no es constitucionalmente pragmátista, por lo menos el af́án de acción y realización le viene ahora impuesto por la coyuntura histórica, dando lugar a un fenóneno análogo al del Nuevo Continente. A lo que hay que añadir como motivos privativos del nuestro el cansancio filosófico subsiguente a más de dos siglos de racionalismo (sus manifestaciones sintomáticas son el existencialismo, el vitalismo, etc.) y, naturalmente, la admiración o adulación hacia el vencedor material y moral en la pasada guerra: victores victis leges dant, como ya decíamos.

$$
\star * *
$$

Nuestra conclusión final no ha de ser puramente negativa. En la dialéctica del pensamiento racional (que no es la dialéctica de las cosas), la negación o antítesis no debe ser valorada en sí misma y como una proposición final, sino como paliadora y refrenadora de los excesos de la afirmación o tesis, para, en combinación con ella, pasar a una síntesis constructiva y mucho más próxima a la verdad. Pues bien, nuestro propósito aquí ha sido esbozar la antítesis o negación en el pleito investigación versus teoría, poniendo en guardia contra los excesos irreflexivos de la primera. Frente al coro entusiasta de turiferarios, dedicados a ensalzar y pedir la cuasi omnipotencia de la misma y que, casi con saña personal, denigran la teoría abstracta (a veces pensando más en el acceso a los dólares que a la verdad), creemos que debe realizarse la voz de la lógica y del sentido común estableciendo cuatro proposiciones:

1." La investigación tiene ciertamente su valor en la ciencia social; pero, entiéndase bien, «su» valor, sin que por ningún resquicio sea legítimo valorarla más allá de sus posibilidades. Sirve para establecer datos concretos de hecho - y aun ahí ha de combinarse con otras actitudes y actividades metodológicas-, siempre mucho más al servicio de veriricación de hipótesis que del descubrimiento de ellas. Las encuestas, estadísticas, etc., suelen tener efectivo valor para comprobar objetiva e inequivocamente (en 
lo que cabe) ciertós juicios o supuestos surgidos ya en la observación cor tidiana e incontrolada, que, no se olvide, sigue y seguixá siendo la primera fuente de informacton del sociólogo.

2. Pero de ninguna manera la investigación puede sustituir a la teora. Si asi fuera, con ello no se llegaria a otra cosa que a la destrucción o negación de la ciencia sociológica propiamente dicha. Correlativamente, la Social Research no ha desplazado los clásicos métodos de formación de conceptos, teoremas y leyes getretales preconizados por Aristóteles, Stuart Mill, etc. Aunque parezca enojoso, el sociólogo no podrá nunca desentenderse de las cuestiones de Metodología y Groseología.

3." Como es natural, la verdadera fórmula para una ciencia empiriológica cual es la Sociologia - que en cuanto uciencia» ha de enunciarse enz fómulas generales y abstractas y en cuaneo «empiriológica» ha de ceñinse a los hechos-m, ha de ser la ecléctica: combinación prudente de teotía e investigación. O como dice Florián Znaniecki, el criterio debe ser caminar entre el Carybdis de la teorización sin más base firme que puras hipótesis dogmáticas y la Scylla de la masa irracional de la confusa y abigarrada información.

4. Finalmente, hay algo que revaloriza la utilidad de la investigacion, pero más allá del recinto de la ciencia. En cuanto determinación rigurosa de situaciones concretas, si no sirve mucho a la teoría pura, tiene en cambio una gran importancia para la zida práctica, o sea para la solución de problemas existenciales, no teóricos... como el uso del termómetro, el electrocardiógrafo o el análisis de sangre de un enfermo no añade nada a la ciencia médica, pero puede ser decisivo para salvar a un enfermo. Digan lo que quieran los sociólogos admiradores de la estadística, los cuestionarios, etc., ninguno, o casi ninguno, de sus conocimientos procede de esas técnicas de investigación; pero, en cambio, el político, el reformador social, el pedagogo de acción, etc, han recibido de ellas una serie de conocimientos verdaderamente utilisimos.

Como hemos repetido a lo largo de nuestro trabajo, no creemos desgraciadamente que esta sencilla postura ecléctica venga recogida por las tendencias actuales de la investigación sociológica; pero sí estamos seguros de que debería ser asi.

ANTONIO PERPINA RODRIGUEZ

Profesor de la Universidad de Madrid y Colaborador del Instituto Balmes de Sociología 


\section{PERSPECTIVAS ACTUALES DE LAS MIGRACIONES}

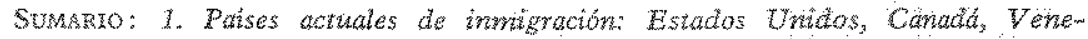

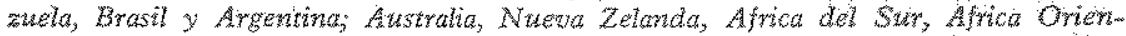
ial, etc-2. Paises actuates de entigracion. Italid, Alemavia, España, Portugal, Ho-

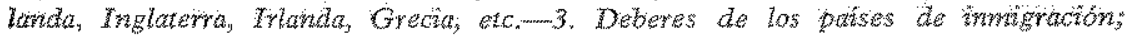
excesivas restricciontes actades. - La poxitica restrictiva de los Estados Unidos, parece opuesta a sus principios tradicionales de libertad e igualdad.-.5, La politica de los otros paises de inmigración: Austratia, Canadá y Nueva Zelanda el Commonweatth; Francia, Brasil, Veneauela, Argentina-6. La politica de los paises de emigración: Italia, Holanda y Grecia; los passes nórdicos; España.

No vamos a tratar aquí de los fundamentos doctrinales del derecho a la emigración. Al Papa Plo XII 10 ha hecho repetidas veces en varios mensam jes $y$ discursos, y prueba de su interés por este problema, en 1946 surgió en el Vationo 1 Comision Internacional Católica de Migración, organtzada como agencia de coordinacion, información y representación del estuerzo

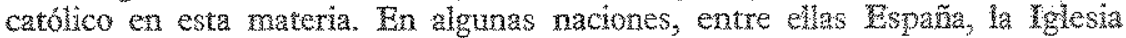
ha establecido también una Comisión de Mhgraciones.

El derecho a la emigración se ha practicado grandemente a través de la historia. Muchedumbres de pueblos hat pasato de un país a tro. Las rizgraciones han sido espontáneas u organizadas, indivisuales o por grupos, temporales o permanentes. Se han examinado las causas y motivos de las migraciones: de orden economico, social, físico, sanitario, político, religiom so, etc. Se har examinado las consecuencias, ventajas y desventajas de las migraciones, tanto para los páses de enigración como para los páses de inmigracion. Las grandes migraciones bumanas constituyen uno de los elementos determinantes de la histcria del mundo. Por ellas nuestro globo se ha poblado; por ellas se har rormado las diferentes razas; por ellas el hombre ha hecho suyos los recursos de la tierra. Libros enteros se hat escrito sobre las migraciones, punto dramático de la historia de la humanidad. Ha habido wigraciones continentales $\mathrm{e}$ intercontinentales. Ha habto migraciones, an en nuestros tiempos, que han sido verdaderos éxodos. Impossble, en pocas páginas, trazar una verdadera sintesis de las migraciones a través de la historia. Nos vamos a limitar a sus perspectivas actuales.

1. Páses actuales de inmigración.-Wn general podemos decir que los 
paises de América son de inmigración y los países de Europa son de emigración. Hay excepciones que saltan a la vista: Francia es un país trás bien de inmigración; en América algunos países, como las Antillas, están bastante saturados de población, y otros paises de la América Central y de la América del Sur no tiene por ahora mucha capacidad de absorcion de intaigrados, sobre todo por falta de capital. Russia y sus satélites han cerrado sus fronteras y all no hay ni emigración ni inmigracion.

En América son cinco los paises que reciben y pueden recibir a inmigrados en gran escala: Estados Unidos, Canadá, Venezuela, Brasil y Argentina.

En América la dersidad es de 8,1 habiantes por klómetro cuadrado. En Europa esta densidad es de 80 . Existe, pues, sna enome desproporción, aun teniendo en cuenta wa buena parte de tierras glaciares y desiertas de América. Si el reparto de habitantes según el territorio hubiera de ser igual en América que en Europa (tienen las dos juntas 800 millones de hab:tantes, sin contar Rusia) tendrían que desplazarse de Europa a América 180 millones de habitantes, o sea muchos más de los 55 mallones que parvieron entre 1846 y 1937 y más de los que partieron de Europa para América desde el siglo XVI hasta nuestros dias.

La población de los paises hispanomamericanos tiene marcadas tendencias ascendentes y los especialistas dicen que entre 1960 y 1974 las tazas hispanoamericanas igualarán o superarán a las razas anglosajonas. Fuera de los páses dichos, bay también abundantes terrenos para colonizar en los Llanos de Colombia, en la región de la Esmeralda en el Ecuador, en las regiones rurales del Uruguay y del Paraguay, en las tierras cultivadas de Chile, en las inmensas extensiones poco pobladas de las tierras bajas de Bolivia.

Fuera de América, se dan grandes territorios aptos para absorber una ingente inmigración, como Australia. Como territorios de inmigración se pueden añadir Nueva Zelanda, Africa del Sur y en algo tambiéa Africa Oriental. La Rusia asiática queda abierta para un aumento de la colonización.

2. Paises actuales de emigración.-En Europa, los paises bálticos y danubianos, ya por la baja de la natalidad, ya sobre todo por una vasta refundición de sus economias, han dejado de ser reservas de hombres para la emigración.

En Alemania, inrnediatamente después de la segunda guerra mundial, la población ofrecía caracteres trágicos con el hacinamiento resultante de la llegada de doce millones de refugiados a un territorio exiguo; pero el desarrollo ingente de su economia ha sorprendido al mundo, ha absorbido la mano de obra, y aún contrata a trabajadores italianos; queda siendo, con todo, un país de emigración.

El país que más necesita de la emigración en Europa es Italia. Comenzó a emigrar en 1870 con ritmo ascendente hasta llegar a una emigración de 872.598 habitantes en 1913. Bajo de improviso en la primera guerra mundial hasta reducirse a 28.311 en 1918 ; en 1920 vuelve a llegar a la 
cifra de 614,661. Luego con la politica restrictiva de Estados Unidos y con la política autárquica lascista se reduce la cifra de exrigración a 41.710 en 1936. Después de la segunda guerra mundial se da alguna modesta emigración a Francia, Bélgica, Inglaterra. En 1951 se alcanza la clfra de 135.096 emigrantes, sobre todo a Estados Unados, Canadá, Brasil, Argentina, Venezuela, Australia.

España dirige su emigración sobre todo a la Argentina, a Venezuela y al Brasil; menores contingentes se dirigen a otros paises de Hispanoamérica. Holanda, Trieste, Grecia, Rortugal, Inlanda e laglaterta son kambién países de emigracion. Los demás países, en menor escala, a excepción de Francia, ofrecen asimismo algunos contingentes.

La necesidad más trágica de emigracion en el mundo se registra en êt Japón, por su enorme crecimiento demográfico y por la vuelta a su ternitorio de los millones desparramados en las conquistas de los uitimos años de tierras asiáticas y del Extremo Oriente; sólo mos pocos contingentes son admitidos en el Brasil. Asia está saturada de población y apenas se descubre, si no es en alguna isla del Pacifico, territorio capaz de absorber a inmigrantes en gran escala. De muchos sitios de Asia se emigraría, si hubiera dónde inmigrar.

Desde 1945 a 1952, segun datos de la Oficina de la Población de Estados Unidos, se produjo una migración intercontinental de 6.312 .000 emigrantes, de los cuales 5.600 .000 pertenecieron a Eutropa.

3. Deberes de los parses de inmigración.-Son sobre todo los países de intrigración los que están obligados a facilitar la emigración de los países quizá excesivamente saturados de población. Ellos son los que han de facilitar el cumplimiento del derecho a la vida y a la emigración, pues generalmente los Estados que tienen necesidad de la emigración no ponen obstáculos a ella y más bien la facilitan. Un mejoramiento del nivel de vida de Europa y de algunos países asiáticos no será posible sino con buenos contingentes de emigración. No es una de las menores paradojas la vuelta a cierta libertad de cambios en lo concerniente a las mercancias y a los capitales y el silencio en lo que toca al problema de la libertad de emigración.

«Las restricciones actuales, dice Röpke, a los movimientos migratorios de las personas constituyen una de las más grandes paradojas de nuestra época. Por una parte, los progresos maravillosos de la técnica y de los transsportes han hecho los viajes menos costosos, más seguros y más rápidos en un grado que parecería milagroso a nuestros padres y abuelos, y han hecho desaparecer obstáculos, muy graves en el siglo XIX, cuando se produjeron las más grandes migraciones que la humanidad ba conocido. Al mismo tiempo, la civilización moderna se ha hecho de tal manera universal que, démom nos cuenta o no, el mundo aparece cada vez más como una sola unidad, cuyos problemas políticos, morales y económicos no se pueden resolver ni en el plano nacional ni en el plano continental. Por otra parte, después de la libertad que se había concedido casi en todas partes para las migraciones internacionales durante el siglo XIX y primeros años del XX, hemos pa- 
Sado a una época de restricciones que no cesa. El establecimiexto permam nente en el extranjero ha tomado un carácter de privilegio que no se puede conceder sino después de un examen y de una selección tigurosa. Se nos da el número de aquellos a los que se ha permitido desplazarse, pero no se nos dicen las cifras de los que se tabrian desplazado si se les hubiese permitido. La política restrictiva es la pendiente lógica del nacionalismo político y económico general y de los programas económicos nacionales, pero es un desafío al espíritu universalista de nuestra civilización y causa de resentimientos internacionales. Si la concesión de la libertad de desplazarse es uno de los derechos más elementales del hombre, del que no se le puede privar sin peligrosas reacciones psicológicas, con estas restricciones el nacionalismo no podría hacer algo peor. Las magraciones constituyen uno de los medios indispensables para el desarrollo económico del mundo entero, desarrollo que interesa a los dos páses, y uno de los medios principales para compensar las desigualdades escandalosas de las posibilidades económicas existentes entre las diferentes naciones del mundo; esta segunda función de las migraciones internacionales implica una muy grave responsabilidad de parte de las naciones más favorecidas" (Cfr. Economia Intemazionale, mayo de 1950, pág. 413).

No hay que suponer que todas las restricciones a la libertad de los movimientos internacionales provienen de la ignorancia, de la mala voluntad, de la falta de buen sentido, de la estrechez de espíritu o de la burocracia. Pero hay bastante de eso en los paises que imponen restricciones; y aunque se quiera dar prueba de la indulgencia más amplia, hay que decir que han sobrepasado una medida razonable. Varios motivos que se dan para las restricciones no soportan la prueba de wn examen crítico. No hay un solo partidario de la paz, de la buena voluntad entre los hombres, de los principios humanitarios, y adversario del egoísmo nacional, que no esté inquieto cuando considera el trágico conflicto entre el interés de una nación y el interés común de todas las naciones.

Desde hace unos treinta y cinco años se registra una tendencia a la autarquía demográfica. Se ha dicho que la acentuación del nacionalismo politico es el áltimo anillo de una cadena de desarrollos económicos, demográficos y sociales, que por sí mismos habrían detenido el flujo de las migraciones en el continente europeo, cualquiera que hubiera sido la orientación de la politica económica y social. Pero las consecuencias desastrosas de la autarquía demográfica aportan una prueba en contrario de los efectos bienhechores de las migraciones.

No es que el derecho a la emigración no tenga sus límites. La teoría liberal, que tiene su origen en el culto excesivo a la libertad, reconoce que el derecho a emigrar es un derecho sagrado e inalienable, que se puede usar a discreción, y que la sociedad no puede suprimir ni limitar. La teoría verdadera reconoce el derecho a emigrar, pero lo subordina a las exigencias del bien común y a la conservación de la sociedad. En virtud de este principio es evidente la necesidad de un control cuantitativo y cualitativo 
de la inmigracion, que salvaguarde algún orden en la evolución dernogtá fica del país de innigración, que salwaguarde la berencia espiritual, las tram

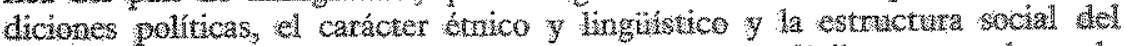
país contra la afluencia de personas indeseabies. Pero rácimmente se abusa de estos argumentos y se puede degenerar en wna politica rabiosamente rackal. Como también se abusa al querer proteger el mercado de rabajo macional por presión de las organizaciones obreras, que se deian llevar a veces por el pensamiento simplista de que un immigrado va a quitar wn empleo a un obrero nacional o va a rebajar la cuantia del salario. Lo que sólo se justifica es una disciplina del movimiento migratorio, no una muralla hatrangueable; una disciplina en buena parte concortada entre los paśses interesados sin la imposicion de condiciones vejatorias, que equivaldria a wa larvada prohibición de la emigración.

Los paises de inmigracion han de aplicar capicales o buscarlos donde estén, aun con la colaboracion de los países de enigracion, cuando ello es posible, para que los inmigrantes puedan desarollar una actividad productiva. Han de procurar trazar planes de colonizacion de tieras sin cultivar todavia. Las organizaciones internacionales han de prestar ayuda a las migraciones, cuando ello sea necesario y posible. La opinión pública no se ha de mostrar egoista. Se tiene que tacilitar el proceso de adaptación y de asimilación de los inmigrados y aplicar a ellos las varias formas de asisrencia ya conccidas.

4. La politica restrictioz de los Estados Unidos. El ejemplo más dramático de policica restrictiva es el ofrecido por los Estados Unidos desde 1921. De 1820 a 1952 entraron en Estados Unidos 38 millones de in matgrados, de los que 33 procedieron de Europa, o sea más de la mitad de la emigractón europea total. Hasta 1921 solo se habia aplicado el principio de la selección, que exclúa a los inmigrantes manifiestamente indeseables, como criminales, deficientes, analfabetos, etc. Pero a partir de 1921 se aphica el principio de la restricción en a numero, a base de preferencias raciales y nacionales, con la única mira de restringir notablemente la aluencia de inmigrados de naciones distintas de acuellas gue habian procurado la mayoria de los primeros colonizadores e inmìgrantes, o sea para excluir a los elentrentos de la nueva eragración. Una comision de 300 mienoros hizo durate tres años investigaciones con el intento aprionistco de demostrar que la nueva inmigración era inferior a la vieja, racialmene, culutralmente, socialmente, Se establecto una cuota para cada nación, que era un porcentaje del whmero de los inmigrantes de la misma que habian entrado en Estados Unidos en wn determinado numero de años. Con la Cuota Act, de 1921, se establece que cada avo sólo se puede admitir a 357.803 inmigrantes, de los cuales 197.630 a disposición de las naciones de vieja inmigración, y 155.585 para las de nueva inmigración. En consecuencia, a Italin le tocó menos de un tercio de los emigrantes que había enviado anualmente a Estados Unidos en los utimos años; en el ventenio $1901-1920$ entraron en Estados Unidos 3.375 .816 italianos, y en las dos décadas sucestvas, 529.670 . 
La legislación de 1924 y de 1929 estableció el mismo principio, pero en vez de tijarse como cuota de inmigración el 3 por 100 de los extranjeros residentes en Estados Unidos según el censo de 1910, se estableció el 2 por 100 según el censo de 1890 , con lo gue el nutnero posible de inmigraites se redujo a 164,667. Con ello a las raciones de vieja inmigración se les redujo la facultad de emigrar en un 29 por 100 , pero a las de nueva inmigración en un 87 por 100 .

La vigente legislación norteamericana tiene cono canon fundamental asegurar de todos modos la preponderancia racial, cultural y politica de la pom blación de origen anglosajón. Alli donde tanto se ha atacado al racismo alemán y la pretendida superioridad de la raza germánica, se esta actuando bajo la influencia de la teoría de la superioridad nórdica de Europa, eso es, de la raza anglosajona. No obstante, las llamadas teorias racistas o raciales son quizá más conocidas por la influencia en los cambios temporales del mapa geográfico de Europa que por la parte que tiene en modelar la polím Lica de aquellas mismas naciones que las combatieron en los campos de bam talla, presentándose como paladines de la libertad y de la dignidad humana. All se piensa que los latinos y los eslavos son física, mental y moralmente de una raza inferior a la de los pueblos anglosajones. Expresiones violentas contra esta inmigración se pueden encontrar en casi todos los volúmenes y articulos racistas publicados en Estados Unidos en las tres primeras décadas del siglo $\mathrm{XX}$, que culminaron con la legislación restrictiva sobre la inmigración. Añadamos que mucho antes ya se había prohibido la inmigración china y japonesa; aunque luego, en principio, se suprimió esta prohibición, prácticamente se hizo nula por la falta adecuada de una cuota.

No es que no se hayan reconocido estos errores en los mismos Estados Unidos. Roosevelt, en 1943, al pedir al Congreso la abrogacion de la ley de inmigración que excluáa a los chinos, decía: «Las naciones, como los individuos, cometen errores. Hemos de ser bastante grandes para reconocer los errores del pasado y corregirlos. Abrogando las leyes que excluyen a los chinos, podemos corregir un error histórico y reducir al silencio la tendenciosa propaganda japonesà. Un diputado, aprobando la propuesta, dijo: "¿Cremos en verdad en 1943, como nuestros antepasados en 1775, que todos los hombres son creados iguales en dignidad, $\mathrm{y}$ en el derecho a ser tratados justamente sobre la base de que somos individuos humanos y no sobre la base de la raza a la que nos ha tocado pertenecer?». Decía también entonces Clara Boothe Luce, representante del Connectitut: «Hace algunos anos decidimos arbitrariamente que ningún asiático estaba cualificado para la ciudadanía norteamericana. El principio que abandonamos cuando tomamos tal decisión era un gran principio americano, quizá el más grande de todos, eso $\mathrm{es}$, que todos los hombres, sin mirar al color, raza o credo han de ser considerados iguales no sólo ante Dios, sino también ante los Estados Unidos. Y el principio que pusimos en vigor fué el principio peligroso hitleriano de la discriminación racial». Se abrogó entonces la leý contra la in- 
migración china, pero las leyes que establecian las cuotas de discriminación racial contisuaron intactas.

La ley de 1952, llamada de McCarran, sobre Inmigración y Mactoralim dad, sostiene cambién vigorosamente la necesidad de retener el principio del origen nacional. Se conservará, dice, «la composición racial de los Ristados Unidos a favor de los inmigrantes de aquellas taciones cuya lengua, tradiciones y sistema politico son afines a la lergua, tradicion y sistema político de esta ración». Decía el Subcomité del Senado para esta ley: "Sin dar fe a alguna teoría de superioridad nóndica, el subcomité cree que la adopción de la fórmula del origen nacional era un método lógico y racional para restringir mumericamente la inmigración de modo que se conserve lo mejor posible la proporcion sociologica y cutural de la población de Estados Unidos. No hay duda de que la fómula favorecía a los pueblos de Europa del Norte y del Deste con preferencia a los de Europa Meridional y Oriental

pero ni las cuotas puestas a disposicion de la primera categoría de naw ciones se lleran, pues no thecesitan enviar tantos emigrantes como se les permite. ¿Por qué, entonces, no se pueden tomar las sobras de la mesa del rico y distribuirlas a los pobres que están esperando su turno detrás de la puetta cerrada de la inmigración? ¿Por qué no permitir que los números de cuota rechazados por las naciones anglosajonas queden a disposición de las naciones superpobladas con cuotas del todo inzuficientes a sus necesidades? Inglaterra, segun su cuota, entre 1930 y 1948 hubiera podido enviar a Estados Unidos 1.248.699 emigrantes y sólo envió 151.000; Irlanda hubiera podido enviar 339.207 y sólo envió a 43.000 . Esta propuesta fué rechazada con estas palabras: «No hemos de desechar la teoría racista por el hecho de que ésta ha dado malos resultados en Alemania; vendría gente que no está satisfecha en su casa ni lo estaria en la nuestra». A la objeción de que con ello quedaban sin utilizar las dos terceras partes de la cuota total de inmigración permitida, McCarran (icatólicol) contestó que «la salvación de América dependía de la preponderancia de la raza anglosajona, la cual en consecuencia tenía que ser preservada de la contaminación de la inmigración no anglosajona».

A esta ley McCarran, que establece que «la entrada de los extranjeros es un privilegio que se confiere teniendo en cuenta el mayor interés de esta nación», Truman opuso su veto, pero fué inútil, pues en la Cámara de Representantes 287 votaron a su favor y 113 en contra, y en el Senado 57 a favor y 26 en contra. No obstante, Washington había dicho en 1873: «E seno de Amética está abierto a acoger no sólo a los forasteros ricos y resm petables, sino aun a los oprimidos y perseguidos de toda nación y religión, a los que daremos la bienvenida con la participación de todos nuestros derechos y privilegios, si con la rectitud y la dignidad de su conducta demuestran merecerlo».

Después de la segunda guerra mundial, se han admizido refugiados, los últimos procedentes de Hungra, como cuota extraordinaria. Pero no es probable que los Estados Unidos modifiquen su posición respecto de la 
twrigracion. Las discusiones desartolladas en el Gongreso en 1952 sobre la ley McCarran muestran que una gran parte de ha pinuton publica es a vorable a las cuotas actuales. Who derauestra lo difichl gue ha de ser akcanzar para Espana, que tene ahora ma cuota de muy pocos centenates, una cuota de 10.000 andalmente, que es la gue se ha agitado wecintenente. Con

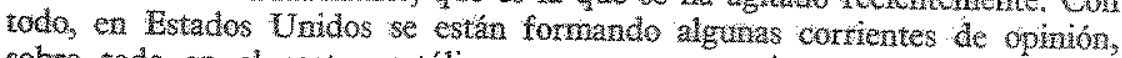
sobre todo en el sector catolico, para que se revise esta poituca de hinmigracion.

5. La politica de los otros patses de inmigración.-Son también páses anglosajones, como Australia, Canadá $y$ Muevo Zelanda, los que permiten en grande la wmigración procedente de países anglosiones, que apenas tienen necesidad de ela, $y$ la niegan a los que acuciadamente la necesitan. Mckensie ha dicho que «la mimgración en el Canadá no es un derecho, sino on privilegio\%. Numerosas han sido las disposiciones que en estos paím ses se han dado contra la inmigración asiáfica.

Decka Mons. Antonituti, cuando era Nuncio en el Canadá, sin duda tem niendo presente el contraste con Italia: "Todo hombre goza de un derecho fundamental que wo se le puede negar: el de emigrar de un pais a otro, de una manera ordenada, pero también de una manera libre, a fin de tener acceso a los bienes de la hierra. Pertenece a la sociedad el encontrar los medios de hacer que este derecho sea un derecho real. Los hombres sin terra tienen el derecho de culvivar la tierra sin hombres, y los obreros de un país sim rocursos naturales suficientes tienen derecho a los recursos naturales abundantes de los paises sin obrerosy.

Sin embargo, en este grupo de naciones se han abolido ya medidas resm trictivas adoptadas entre las dos guerras y se va manifestando una mayor amplizud en la recepción de inmigrantes. Se acoge ya a holandeses, a otros nórdicos y a italianos con mayor facilidad. Con todo, se tiene por más deser ble la inmigración británica y escandinava, fácil de asimilar, gue no la de otros grupos, como los de Europa Meridional. Decua el gobierno neozelandés: "Estimamos que es importante precisar que si uno se propone asinim lar la inmigración de europeos de otro origen, ésta ha de presentar cualdades propias para asegurar una asimilacion total y relativamente rípida y adoptar concepciones netamente neozelandesas»,

Pero el problema de los obstáculos puestos en estos países, sobre todo en Australia, a la inmigración asiática es gravisino. La política del Comm monwealth, que ha inclúdo a la India y al Pakistán, encierra una contradicción. Por el Estatuto de Westminster de 1931 se concede a los miembros de la comunidad britanica igualdad juridica, sin subordinación de uno a otro de los miembros en ninguno de los aspectos, en las relaciones internacionales exteriores. Pero los ministros de Su Majestad en Australia excluyen a los indios; se piensa en la redistribución de la población blanca, pero a la India y al Pakistán, y mucho más a la China y al Japón, se les ponen barreras para la emigración. Esta empresa arriesgada de acentuar el conflicto racial no deja de ser un peligro permanente para la seguridad mundial. Cuanto más 
waya presionando en los paises del Assia el problema de las subsistencias, con tanto mayor probabilidad acabaráa por denunciar la politica de la puerta cerrada instaurada por los blancos, como una intolerable inzusticia, sobre todo crando se ve a la Unión Soviética que concede wn puesto preeminente a la igualdad de las razas. El mistao Dr. Thompson, ya en 1929, exhontaba a Australia a admitir a japoneses, al menos en sus zonas tropicales, donde cabrían de 25 a 50 millones, y un número todavía más alto de chinos.

En cambio, los países de origen latino dan más facilidades para la into migración. Francia desde 1850 ha acogido a gran numero de extranjeros de todas las nacionalidades de Europa y aun de otros continentes. Concede generalmente las libertades públicas en condiciones de paridad con los ciudadanos franceses. Da facilidades para gue se integren en la comunidad nam cional. Ha establecido planes de inmigración después de la segunda guerra mundial. Ha firmado acuerdos con los países clásicos de emigración, sobre todo con Italia. Ha creado el Oficio Nacional de Inmigración con sus misiones en Italia, y en Alemania con el encargo de buscar, seleccionar, reagrupar y enderezar a sitios de trabajo a los candidatos inmigrantes. Ha firmado con la Organización Sindical Española un contrato para la inmigrä ción temporal en orden a ciertos trabajos agrícolas.

El Brasil, por ley de septiembre de 1845 , tambiér estableció el sistema de cuotas. El contingente anual de inmigración tenía que ser igual al 2 por 100 del número total de inmigrantes provenientes de cada país, entrados desde enero de 1884 a diciembre de 1933 . Se da la preferencia a agricuitores y técnicos. La ley tiene disposiciones que miran a la obtención de terrenos de cultivo para los colonos, a las ayudas procuradas por las autoridades federales y a la administración de las zonas de colonización. La Constitución de 1946 es más flexible; desaparecen las cuotas y se encomienda a la legislación la regulación del tráfico inmigratorio. El Consejo Nacional de Emigración se ocupa de los planes de este género y se propone estimular la emigración hacia este país.

El Gobierno venezolano estimula con insistencia la inmigración y ha enviado comisionados para la emigración a varios países. En el mismo orden favorable se encuentra Argentina. Otros países americanos favorecen la inmigración. Otros no tanto por no considerarse ya países a propósito para ella.

6. La politica de los paises de emigración-L -La nación más activa en impulsar la emigración en Europa es la que más la necesita, Italia. Ha firmado pactos de emigración con Australia, Brasil, Venezuela, Argentina, Uruguay, Canadá, Inglaterra, Bélgica y Francia, además de la cuota que le toca para emigrar a Estados Unidos. Ha reorganizado el Instituto de Crédito para el Trabajo en el extranjero, que se inició con un fondo de 10 millones de dólares del Plan Marshall. Otras grandes cantidades se han destinado y se están destinando para cubrir los gastos de las misiones de estudio y para financiar la asistencia técnica a los servicios de emigración. Se financian empresas en el extranjero que procuran dar trabajo a los italianos. En el convenio con la Argentina de 1948 se preveía la llegada a aquella na- 
ción de medio millón de italianos en cinco años; en el acuerdo consta el empeño en emplear todos los medios para favorecer la instalacion en el territorio argentino de la masa concordada; se estableció una Comisión Mixta en Buenos Aires compuesta por funcionarios italianos y argentinos, expertos en estos problemas; Argentina se empeña en colocar adecuadamente a los colonos italianos e Italia participa en ello técnica y financieramente; el gobierno argentino procura medios para adquirir tierras y concede préstamos bancarios para promover y desarrollar la producción; su aporración no ha de ser inferior a la apotación de capital italiano depositado en la Argentina para financiar los gastos de la transferencia de las familias de los que están ya en el país y los gastos en el periodo de la primera colocación.

Holanda y Grecia fomentan sistemáticamente la salida de una parte de sus ciudadanos y les ayudan a soslayar los obstáculos que puedan presentarse a su emigración.

Los passes nórdicos, Dinamarca, Finlandia, Yslandia, Suecia y Noruega, han concludio un convenio que establece un mercado común de empleo entre los cinco países. Suecia ocupa a unos 65.000 trabajadores de Finlandia y Dinamarca. Noruega ocupa de 10.000 a 15.000 , la mayoria daneses,

Espaz̃a necesita la emigración. Aumenta actualmente su población en unos 225.000 habitantes y se calcula que sólo una mitad se puede absorber de una manera adecuada en las fuentes de producción nacional; a ello hay que añadir el exceso crónico de mano de obra agrícola. En 1912 llegaron a emigrat hasta 200.000. El promedio del periodo 1946-1951 fué de 50.000, Hoy se llega a una cifra aproximada de 70.000. Se ha demostrado que la emigración aislada y espontánea, que es la que hasta ahora ha regido, resuelve poca cosa tanto a los que están en Espraña como a los que están en los países de inmigración. Diversos textos legales regulan la emigración, pero hasta ahora no ha habido un plan de emigración. Se ha firmado un convenio con Santo Domingo, pero ya se puede suponer que no se puede tratar sino de un plan de modesto alcance. Algo más prometía el convenio de migración hispano-argentino, de 15 de octubre de 1948 , pero no se ha cumplido. Con el establecimiento en 1956 del Instituto Nacional de Emigración parece que se presentan perspectivas esperanzadoras. Actualmente la Comisión Católica de Emigración, en relación con los organismos oficiales, facilita la emigración de los familiares de los que se encuentran ya en la América Latina. Allá tiene que dirigirse sobre todo nuestra emigración. *España, dice Ruiz Almansa, tiene una demografía desbordante y una economía deficitaria. Por su población España puede y debe tener un lugar preponderante en el mundo. Tenemos que combatir a la defensiva en el campo económico y lanzanos a la ofersiva en el campo demográfico internacional, ofensiva incruenta, claro está, en que sólo se persigue llevar sangre nueva y cultura antigua a otros pueblos que tienen ya sangre y cultura española en las venas y en los cerebros.n

Martin BRUGAROLA, S. J. 


\section{MISION DE LAS ASOCIACIONES CRISTIANAS DE TRABAIADORES}

Sunarto: El trabajador cristiano es el misionero de la 1 glesia en la clase obreran-Necesidad de znion conseguida a trawés de las asociaciones cristianas de trabajadores,-Su sello característico: el apostolado.-Su mision en general: formar cizadadanos conscierzes y católicos militantes; conquista para Cristo del obrero por el obrero.-Su misión en concreto: I. Para sus propios miembros en Células de apostolado cristiano moderno.- Hacer sentir la presencia de Cristo en el mundo del trabajo; realizar el concepto cristiano del trabajo; alegría en el trabajo; 4 so cristiano del tiempo libre. ¿Promoción obrera o elevación del proletariado? Espiritu cristiano inegral.-II. Para otras instituciones son Vivero de virtudes y de hombres competentes. - Suts relaciones con los Sindicatos: hipótesis de libertad sindical; hi. pótesis de unidad sindical-Delaciones con la politica: como organización han de mantenerse al margen.-Relaciones con lo temporal: no pueden desentenderse- Relaciones con el movimieno obrero.- III. Ante un nuevo orden social: corporatiwismo.-Formación de la clase obrera" Mistica obrera cristiana; ¿Cofradias?-Enílogo. En la vanguardia de la evangelización de la clase trabajaclora. En esta labor han de colaborar todas las clases de la sociedad. Las asociaciones cristianas de tra bajadores son la presencia de la Iglesia en el ambiente obrero y a su wez la presencia de la clase trabajadora en la Iglesia.

En una audiencia pontificia, un numeroso grupo de trabajadores rodeaba a S. S. Pio KII, quien iba estrechando uno a uno sus manos. Un muckam cho, al tener la suya unida a la del Papa, exclamo: "Mi padre es comunista" yo lo convertíém. Su Santidad abrazó llorando al muchacho, le apretó contra su corazón y se dirigió después a los obreros: «Las misiones del interior, en fábricas y ambientes de trabajo, serán muchas veces más importantes y difíciles que las del exterior. Yo os nombro misioneros del interior. Sois los misioneros de la Iglesia en la clase obreray.

He ahí resumida en una anécdota la misión del trabajador cristiano. Ahora bien, esta misión, si se quiere ver realizada en toda su amplítud, necesita de un aglutinante externo. No se trata de agrupar simplemente a los trabajadores cristianos, sino de unirlos en orden a una misión determinada $y$ con unos métodos comunes de acción. Esta visión y estos métodos han sido. 
dados a conocer en lo doctrinal en varios discursos de Pio XII. Por otra parte, las Asociaciones Cristianas de Trabajadores, al enfrentarse con los problemas planteados a la clase obrera, han aplicado las directrices de la Iglesia: ha sido un confrontar la doctrina con la realidad. Como consecuencia se ha logrado delimitar sus funciones y concretar su mision.

\section{Su sello caracteristico y su misión en general}

Conviene notar ante todo que las asociaciones objeto de este estudio con las que jurídicamente pueden llanarse cristianas, por depender de alguna manera de la autoridad eclesiástica. Pio XII, al dirigirse a las asociaciones cristianas de trabajadores, se refiere exchusivamente a las que tienen un carácter apostólico. Bajo esta denominación se incluyen aquellas organizaciones cuyo fin principal es formar moral, treligiosa y culturalmente a sus miemm bros y conquistar para Cristo a la clase trabajadora. Esto no excluye el que dentro de su fin especifico puedan tener obras narginales de carácter económico, de previsión o asistenciales. Con todo, lo religioso les atane primariamente. Otras agrupaciones obreras podran, si lo creen oportuno y con la aprobación eclesiástica, realizar accidentalmente, secundariamente, wna ta rea apostólica complementaria, pero no como fin primario suyo, y mucho menos en exclusiva.

Ejemplo de estas obras marginales económico-sociales creadas en buena parte gracias a la labor de formación de organizaciones culturales y apostólicas lo tenemos en Bélgica. La JOC ha sido el auténtico fundamento y escuela de dirigentes de todo el Movimiento Obrero Cristiano belga y aun mundial. Este Movimiento, MOC, agrupa obras económico-sociales (Sindicatos, Mutualidades, Cooperativas) y organizaciones culturales y apostólicas (JOC, Equipos Populares).

De todo esto podemos deducir que el campo de acción de estas asociaciones, aunque limitado en su origen, puede llegar a tener una amplitud considerable, si se tiene en cuenta que de ellas pueden salir los dirigentes no sólo de otras asociaciones obreras, sino también de la sociedad. Es mision suya el formar los ciudadanos conscientes de la patria, los católicos militantes que estén dispuestos a defender a Cristo y a su Iglesia por encina de todo.

Pio XII resume así este sello característico: «La profunda razón de ser de vuestra asociación, como de toda otra asociación católica, se ha de buscar no en el temor de otros movimientos ni en la lucha contra otros, ni tampoco en aquel sentido de solidaridad que une a los miembros de una misma clase, sino en el deber íntimo y en el celo que sentís como católicos de haceros apóstoles de Cristo ante vuestros hermanos que ignoran o rechazan su mensaje salvador» $(1-\mathrm{V}-1956)$.

Hay que conocer de cerca a estos apóstoles obreros, agrupados en asociaciones, que revisten diversos nombres y modalidades, pero que están unidos por un heró́smo y abnegación llevados a cabo como algo corriente. Dia 
tras dia luchan por conquistar para Cristo a sus compañeros de trabajo, por capacitarse cada vez más.

En las normas de especialización dictadas con carácter general por ia Jerarquia en España, y aprobadas por el Sumo Pontífice, se consignar como finalidades principales de la Acción Católica Obrera, el sdufundir en todo el ámbito de la nación, entre las clases obreras, wn alto ideal de conquista espiritual del pueblo para Cristo, y de conquista social de unu sano bienestar para todos. Nuestra Hermandad obrera de Acción Católica concreta así su misión: Integrar con sabiduría y discernimiento el apostolado de los obreros en la economía general del apostolado del hombre modennos. Fis la conguista para Cristo del obrero por el obrero, según los deseos de Wio XI en la «Quam dragesimo annon.

Su misión en concreto: I. Para sus propios miembros son células de apostom lado cristiano.

El documento básico del presente trabajo es el discurso de Pio XII a las Asociaciones Cristianas de Trabajadores Italianos (ACTT), del 11 de marzo de 1945, completado con otros documentos dirigidos en su casi totalidad a las mismas. El Papa empieza preguntándose: «¿Qué son las Asociaciones Cristianas de Trabajadores para sus propios miembros?». La respuesta no puede ser más categórica: "Ante todo son células de apostolado cristiano moderno».

La vida moderna, con su gran movilidad y la apostasía del mundo del trabajo, exige nuevos métodos de apostolado: el ministerio sacerdotal resulta insuriciente; los prejuicios de la clase trabajadora para con la Iglesia son enormes. La acción cristianizadora de la Parroquia recibe una ayuda eficaz con estas células complementarias que llegan mucho más lejos de lo que puede llegar el párroco por si mismo, y que «mantienen, culuran y custodian en el mundo del trabajo el fundamento religioso y moral de la vida, de manera stempre adaptada a las circunstancias especiales de cada momento (11-III-1945).

Los enemigos de Cristo sacan provecho de todas las circunstancias: el taller, la fábrica, el barrio, se convierten en focos de idess malsanas; all se envenena a los trabajadores...; alli hay, pues, que acudir para lanzar otras ideas en pugna con aquéllas, que aireen un ambiente viciado por el materialismo y la inmoralidad, y lleven consigo una corriente vivificadora. Esta labor no es sólo indispensable donde el aire está ya enrarecido, sino también donde todavía se conserva puro, "porque en todas partes las condiciones prácticas y cotidianas del trabajador asalariado desconciertan las inteligencias hasta de los hombres profundamente creyentes, y suscitan problemas que mientras tocan los intereses políticos y morales exigen el socorro y la asistencia de la Iglesia» (11-III-1945).

Su primera misión es, pues, hacer sentir la presencia de Cristo en el mundo del trabajo, en sus familias, entre sus propios miembros: No olvi- 
dểs jamás que vuestu primera preocupacion es la de conservar y acrecentar la vida cristiana en el trabajadory ( $-\mathrm{V}-1955)$. «Way artes y ofichos a los que parece inherete casi por ingtinto natural el bercicio del apostolado. Pexsad en el maestro, el educador, ell escritor, el medico, el enfermero. 2 No son ellos acaso cono los auxiliates natos del sacerdote? Mitad también a los que en su carrexa de empleados obtienen el oficio de jefes: ¿quién podra dudar de que esos pueden practicar el celo de las almas? Con razón asimismo se ha hablado de la acción social, es dacir, apostolica, del jurisca, del oficial, del ingeniero. Pero tambien en los oficios manuales del obrero, del artesano, del agriculor, el ardor anostólico, por poco que encienda el corazon, sabe encontrar fácilmente pábulo a su llama e inflanar a los oros̀ (20-1X-1942).

\section{Concreciones: Concepto cristiano del trabajo}

pio XII sefiala algunos puntos en que concretar esta vida cristiana. Fa primer lugar cira la santificación de la vida mediante una concepción verdaderamente cristiana del trabaio. Concepción fundada en el ejemplo de Crists ro, que comezzó a trabajar antes que a enseñar, y a ser humilde obrero antes que Maestro de todas las gentes; fundada en la idea de que el trabajo es un servicio de Dios, y uaunque es cierto que muchas veces hace sentir la fatiga hasta dolorosa y áspera, sin embargo, en sí mismo es hermoso y capaz de ennoblecer at hombre porque prosigue, en cuanto produce, la labor iniciam da por el Creador y forma la generosa colaboración de cada uno al bien contins $(27-111-1949)$.

\section{Alegria en el trabajo}

Es una consecuencia de lo anterior. Quienes consideren la dignidad del trabajo tendrán mucho conseguido en orden a trabajar no a la fuerza, sino con alegría, con elevadas aspiraciones. Disposición expresada gráficamente en aquella tan conocida anécdota de tres canteros: uno considera su trabajo como una carga insoportable, otro ve los frutos que le reporta, el terceto trabaja entusiasmado porque está levantando una catedral... Cuando la sociedad logre este entusiasmo profesional habrá dado un gran paso hacia una mayor felicidad posible en esta vida. Pero ¿cómo conseguirlo?

Hoy la clase trabajadora y en general casi todas las clases sociales carecen de conciencia profesional. La raíz está en que no se ama el trabajo. Pero ¿cómo se puede amar, si no se halla en él satisfacción alguna?: ¿Satisfacción material? Imposible con un salario insuficiente. ¿Satisfacción espiritual? : Por trabajar por el bien común? Se necesita temple de héroe para destrozar la propia vida sin esperanza de gozar de los frutos que reporta este deshacerse continuamente por los demás... ¿De saber ver en el trabajo un complemento de la labor divina? Si se le hubiera enseñado esta concepción cristiana del trabajo..., pero no se le enseñó nada de esto, y sólo aprendió a considerar el trabajo cono una carga insoportable... Si liego con algún ideal 
a su primera hora de trabajo, ya se cuidaron el ambiente y las circunstancias taborales de ahogar en flor lo que quizá era fruto de grandes esfuerzos de educadores...

\section{Uso cristiano del tiempo libre}

Complemento de la mision cristianizadora del trabajo, es el uso cristiano del tiempo libre, fa santificación del domingo y de las fiestas, la vida de milia. Es este un problema cuya magnitud y trascendencia nos obliga a considerarlo aungue ś́lo sea de paso,

En primer lugat, se presenta la falta de tiempo disponible en nuestras clases trabajadoras. Con la jornacia de ocho horas no se alcanza lo suficiente para la vida... Es necesario hacer horas extraordinarias, afiadir media jor rada y a veces incluso jornada entera..., dedicarse a trabajos complementa. rios, chapuzas, como le llaman algunos... Las consecuencias son a todas lum ces evidentes: agotamiento del trabajador, descenso del rendimiento, des aparicion de la vida de familia, imposibilidad de acercarse por la Iglesia, incapacidad para todo esfuerzo mental en orden a completar la propia cultura...

En la solución de este problema poco pueden hacer las asociaciones de que tratamos. Intervienen múltiples factotes, entre los que no juega ciertam mente papel secundario lo bajo de muchos salarios, lo reducido de nuestra renta nacional, y lo que es peor, la mala distribución de la misma entre los diversos estratos sociales. Es labor de todos el conseguir que nuestras clases trabajadoras vuelvan a disfrutar de la jornada de ocho horas, conquistada con tanto esfuerzo por las generaciones pasadas. Con todo, supongamos que mañana es ya realidad esta reducción de la actual jonada de trabajo. Estaria de acuerdo con ello el trabajador, aun supuesto un salario digno? ¿No se dejaria llevar por la inercia y paulatinamente volvería a prolongar su jornada, cayendo de nuevo en los males que se pretendia obviar?... Es misión de las asociaciones obreras el ir encaminando a sus miembros hacia el aprovechamiento cristiano de los tiempos libres que se logren. Sólo así seráa posible la deseada elevación del proletariado: nuestras clases trabajadoras necesitan cultura; mientras no se les dé tiempo para alcanzarla, la sociedad permanecerá estática en la injusticia, o lo que es peor, dinámica en el desequilibrio económico y social, con tendencia al caos, en vez de avanzar hacia el progreso.

\section{Promoción Obrera o Elevación del Proletariado?}

Hemos hecho referencia a la elevación del proletariado. Esto nos lleva a decir una palabra acerca del concepto cristiano de la llamada Promoción Obrera. Este término, que empieza a usarse también en España, y sólo insinuado por el Papa, se identifica inadecuadamente con el término tantas veces repetido por Pio XII de la elevación del proletariado. Elevar al pro- 
letariado, en la mente del Sumo Pontifice, supone la colaboración de todas las fuerzas vivas sociales, incluídos los mismos interesados. Es la realización práctica de la doctrina del Cuerpo Místico.

La Promoción Obrera, tal como suele entenderse en las organizaciones obreristas, aun católicas, supone por lo menos un prescindir de la ayuda de las otras clases o fuerzas sociales. La clase trabajadora, por sí misma, espera promoverse al sitio que realmente tiene derecho para que sea reconocida en su plenitud la dignidad humana y la del trabajo. Si esta exclusividad no supone lucha de clases, o dictadura del proletariado, moralmente no habra nada que decir. En el orden práctico, resultará muy difícil de conseguir esta promoción aś entendida, y más todavía si se quiere evitar el escollo de la lucha de clases.

Es cierto que los trabajadores han de laborar colectivamente por su promoción social, prescindiendo de si se les ayuda o no, pero no deben rechazar la ayuda cristiana, fraternal, a la que están obligadas las otras clases som ciales y todas las fuerzas vivas de la sociedad. Hemos dicho fraternal por que quizá la desviación apuntada sea debida a una ayuda paternalista que hiere la dignidad del trabajador, deforma a nuestras clases trabajadoras $\mathrm{y}$ retrasa la hora de su legítima participación en la vida nacional.

\section{Espiritu cristiono integral}

En la tarea encomendada a las asociaciones cristianas de trabajadores no hay que olvidar que para elevar cristianamente a la clase obreta es preciso impregnar de los verdaderos principios de Cristo toda la vida del trabajador, como sería necesarísimo hacerlo con las demás clases sociales.

En este punto conviene «considerar las cosas prácticamente y con toda sinceridad». Pio XII es padre solicito que defiende a sus bijos de la injusticia, pero su amor no le ciega: en sus documentos proclama la verdad para todos sin distinción social: un día a los nobles y patricios romanos, otro a los comerciantes o industriales, otro a los gobernantes..., y también les llega su turno a los trabajadores. Citemos algunos párrafos suficientemente claros para poder prescindir de comentarlos:

«Hay por todas partes una sensación de malestar y de disgusto. El trabajador no está contento con su suerte y la de su familia. Asegura que lo que gana no es proporcionado a sus necesidades. Ninguno como la Iglesia ha defendido y defiende las justas peticiones de los trabajadores. Pero semejante desproporción e insuficiencia ¿se debe siempre únicamente a la escasez de lo que se gana? ¿No entra en ello para nada el aumento de las necesidades? Sin duda alguna que hay necesidades que tienen que ser satisfechas urgentemente. Los alimentos, el vestido, la habitación, la educación de los hijos, lo necesario para el alma y para el cuerpo. Pero queremos aludir a otras exigencias que demuestran de qué manera la moderna y anticristiana ansia de placer y la despreocupación tienden a penetrar también en el mundo obrero. Las arduas circunstancias económicas del tiempo de la 
guerra hicieron perder hasta la posibuluad del ahoro. Pero hoy todayía no Se ha melto a su sentido ri a su ideas (29-VI-1948),

El Papa se pregunta cómo en semejantes condiciones de espiritu se puede tener una conciencia clara y recta para el desmpeño de las múltiples responsabilidades que la hora presente va ofreciendo al mundo del trabajo: ad ministración de los bienes y servicios de sus organizaciones, participación en la dirección de la economía del país, on la gestión de las empresas... De ahi se sigue la mision, tan dificil e importante, de las asociaciones obreras, de «promover en cada uno el espíritu de parsimonia crisciana, de cuidadosa delicadeza en todo lo que se refiere al bien comin, para que siempre prem valezcar en aquellos que tienen plena conciencia de su responsablidad» (29-VI-1948).

Ciertamente que no toda la culpa de esta irresponsabilidad está en la clase trabajadora: la dureza de su trabajo, la contrinada bumilación a gue se veía sometida por clases más elevadas, st arrinconamiento social... Le han levado a buscar la compensación de sus males en el materialismo. Lo adm mirable es que después de todo esto queden todavia virtudes morales enraizadas en la clase rabajadora.. Los ejemplos que de continuo recibe de otras esferas sociales, el ambiente que respira por doquier, le estimulan er su afán desmedido de diversiones y placeres, ann a costa de lo sustancial para la vida.

Ante este problema, no hay que buscar la solución en menguar todavia más los ya demasiado escasos ingresos del trabajador, sino en formarle por una parte con el ejemplo de todos, y por otra mediante la ayuda de los mejores de entre ellos, en las organizaciones obreras. «D sueldo o salario no son las fuentes únicas de riqueza para el hogar domesuco. Los conocimientos adquiridos en la escuela, o los que se refieren al propio oficio, arte o indusm tria, la salud física, el bienestar de la madre y del niño, una habitación sana y limpia, son elementos que concurren también al embellecimiento y a la alegría del hogar, con gran provecho de los miembros de la familia. iQué magnífico campo de trabajo éste para las asociaciones cristiznas de traba jadores! $\%$. Las otras clases sociales pueden y deben cooperar a la educación del pueblo, kpero éste debe estar intimamente dispuesto a cooperar en este rabajo apostólico, a querex ayudarse a sí mismo, a tenex de sí mismo un concepto alto y verdaderamente cristanos (29-VI-1948).

Como resumen del primer punto de la mision de las asociaciones cristianas de trabajadores, citemos las palabras de Pro XI, en 1 de mayo de 1956: "Mantened intacto y fime el fundamento religioso cristiano de vuesm tras agrupaciones... Cualquiera que pueda ser el porvenir del mundo del trabajo, siempre será necesario que un grupo mayor o menor de apóstoles imprima o mantenga en la vida social el sello del reino de Cristo, actuando - sosteniendo los valores que aprecia sumamente todo hombre y todo trabajador maduro y consciente, como son la justicia, la libertad y la paz en la colaboración positiva de las clases». 
11. Para otras instituciones son wiwero de virtudes y de hombres competertes

En la mente del Papa figuran todas las instituciones públicas en las que es necesaria la contribución de los trabajadores, Las asociaciones cristinas de trabajactores deben ser envero de las witudes sociales, de la rectivd, de la fidelidad, del hacer las cosas a conciencias. As uprocurarán a las orrats instutuciones sus mejores miembros, sus mas seguros dirigentes, hombres y mujeres, que sabrán despertar y mantener vivo el espiritu de resporsabilidad y de soldaridady, sh el cual ninguna obra, por buena que sea, puede prosperar.

Se ha dicho que las instivuciones son lo que son sus hombres. Actualmente existen múluples instiuciones culurales, de prevision, asistenciales, laborales, en las que tienen o deberan tener entrada los trabajadores. Si las clam ses obreras se preparan socialneate y actuan en estas instiuciones, wh hatito de vida las informari y los primeros beneficiados seran los mismos trabaw jadores.

\section{Sus relaciones con los Sindicatos}

El Sumo Pontifice hace referencia al caso especifico de Italia, en donde se había constituido hacía poco la unidad sindical, no por fuerza de la ley, sino por mutuo acuerdo de los grandes bloques obreros. El papa insiste en que las renuncias que se hicieron upor parte de los trabajadores cristianos no acarreen daño a su causa, sino que consigan el ruto esperado por todos los trabajadoress.

A continuación, Pio XII resume admirablemente las relaciones entre ambas agrupaciones y hasta qué punto puede permitirse esta colaboración con un sindicato nacido fuera del cauce cristiano. "Esto supone, como condición fundamental, que el sindicato se mantenga dentro de los limites de su finam lidad esencial, que es la de representar y defender los intereses de los trabajadores en los contratos de trabajo. En el ámbito de este oficio, el sindicato, naturalmente, ejercita un influjo sobre la política y sobre la opinión pública; pero no podría ir más allá de aquel limite sin ocasionar graves perjuicios a sí mismo. Si alguna vez el sindicato, como tal, en virtud de la evolución política y económica, viniese a ejercer casi un patronato o derecho de disponer libremente del trabajador, de sus fuerzas y de sus bienes, como en otras partes sucede, el concepto mismo del sindicato, que es una unión para la propia ayuda y defensa, quedaría alterado o destruido. Puestas estas premisas, el sindicato y las asociaciones cristianas de trabajadores tienden a un fin común, que es el elevar las condiciones de vida del trabajador» (11III-1945).

Analicemos ahora la misión de las asociaciones objeto de nuestro estudio, en las hipótesis de un régimen de libertad o de unidad sindical. Seguimos en esto las ideas vertidas por el Excmo. Sr. Dr. D. Vicente Enrigue Taran- 
cón, Obispo de Solsona, en la lección que tuvo en la Semana Social española de 1955 .

En la primera hipótesis: libertad sindical, esta mision se puede conctetar en tres puntos:

1) Impulsar a sus miembros a afiliarse en un Sindicato. Para ello es preciso convencenles de la necesidad de agruparse los hombres entre st y mucho más cuando hay bienes comunes en peligro.

2) Formar a sus miembros para que sepan escoger aquel sindicato que zi ponga en peligro su fe, ni defienda doctrinas contrarizs a las sustentadas por la Iglesia. Caso que no haya ningún sindicato que reuna estas condiciones, entonces deberán intensificar la formación de stas miembros para que sean capaces o de constituir por sí mismos un sindicato con sanos principios o, si esto fuera imposible, el valexse de los existentes y aun actuar en ellos sin que peligre su te y tendiendo a mejorar sus doctrinas malsanas.

3) Wa ningún caso pueden estimular la lucha de clases. podrán y deberån estimular el sentido de clase, el orgullo de sentirse trabajadores, el deseo de poder alcanzar puestos dirigentes en la sociedad, pero todo esto sin odiar a quienes los ocupan actualmente. El aprecio de los propios valores no debe ser tan exagerado que lleve consigo el desprecio de los auténticos valores de los demás.

En la hipótesis de unidad sindical, concretemos su misión en cuatro puntos:

1) Evitar el absentismo obrero del sindicato. Cuando el hombre no considera una cosa como suya, generalmente se abstiene de intervenir en ella. Este es el peligro que puede existir en un régimen sindical más o menos impuesto desde arriba. Esta apatía obrera puede estar incrementada por la pasividad del Sindicato en la defensa de los intereses de sus miembros; pero aun así el obrero tiene el deber de incorporarse activa y lealmente al sindicato como medio para defender en lo posible sus intereses y los de sus compañeros, y colaborar a la paz social. Una colaboración leal en todo aquello que no sea intrínsecamente malo le da derecho a exigit. El absentismo no le da derecho a nada.

2) Formar a sus miembros para que realmente influyan en el sindicato único, y con influencia eficaz, que logre la finalidad del sindicato, sin desviaciones políticas de partido o de intereses mezquinos. Si se tiener los principios bien claros se pondrán todos los medios para influir realmente. Puestas las premisas, los afiliados deben sacar por su cuenta las consecuencias en cada caso particular.

3) Urgir la obligación de elegir a los mejores para los cargos sindicales.

4) Deben formar de tal modo a sus miembros que sean capaces de resistir el halago de las mil ocasiones que se les pueden presentar, una vez

¿ Cfr. «La Moral Profesional». Semanas Sociales de Espara. XV Semana. Sa lamanca, 1955. 
encumbrados en cargos sindicales, para hacerles desertar de sus ideales obreros y aun cristianos.

Quizá alguno crea que esta misión debería completarse en el sentido de preparar a sus miembros para un régimen de libertad sindical. No es misión de las asociaciones de carácter apostólico el crear por sí mismas asociaciones profesionales representativas con fines reivindicativos. La asociación como tal no puede tener esta misión directamente. Sus miembros pueden capacitarse lo mejor posible pensando en un futuro de libertad sindical, pero su modo de proceder debe estar desligado por completo de la asociación. Dentro del catolicismo caben muchos matices: no debe darse ninguno determinado a la Acción Católica.

Si las asociaciones cristianas de trabajadores han formado debidamente a sus miembros, con facilidad caerán en la cuenta los individuos, que, aun deseando llegar a un régimen de libertad sindical, no podrán hacer nada mejor que iniciarse actuando dentro del sindicato único. No se puede ni debe colaborar con el error, en lo que es erróneo, pero en el campo de lo que no es intrínsecamente malo, aunque quizá sea menos deseable, colaborar "pro bono pacis» o en orden al bien común, o en orden a un futuro mejor, suele traer consigo mayores bienes que la posición contraria.

Pio XII cita la actuación de los trabajadores italianos en este sentido. "Los dirigentes del nuevo sindicato único han reconocido la altísima apor. tación espiritual que los trabajadores católicos han traído a la obra de la Confederación, y han rendido homenaje al aliento de espiritualidad que in funden en la misna Confederación para el bien de todo el movimiento obre* ro». La colaboración no impidió que llegado el momento de cambiar el régimen sindical los trabajadores católicos estuvieran preparados para la libertad. CLo hubieran estado si durante los dias de la unidad se hubieran aislado?

Termina el Papa resumiendo la misión de este modo: "Así comprenderéis qué importante deber y obligación de impulso, de vigilancia, de preparación y de perfeccionamiento corresponde a las asociaciones cristianas de trabajadores, por lo que toca al trabajo sindical» (11-III-1945). Luego sea cual sea la hipótesis sindical que se dé en la realidad, las asociaciones cristianas de trabajadores tienen una altisima misión: formar a los hombres que deben dirigir estas instituciones, que deben llevar el espíritu del Evan." gelio y hacer prevalecer los principios de la justicia según el orden establecido por Dios en el mundo, sobre la fuerza puramente mecánica de las organizaciones; los príncipios del amor y de la caridad sobre el odio de clases.

Como resumen, podemos citar dos párrafos del Manual de la JOC: «La educación sindical cristiana no puede quedar puramente teórica, sino que debe ser activa y positiva; debe hacer participar a los jocistas en la vida, en la acción y en la organización sindical». «Esta participación en la vida sindical no puede poner en peligro la formación, la acción y la organización 
jocistas, que permanecen independientes de la acción sindical y abrazan toda la vida de los jovenes trabajadores»".

\section{Relaciones con La Politica}

En lo que a la politica se refiere, Pio XII señala ha inutuldad de las leyes e instituciones, si se vive con el temor de la arbitrariedad y del subjetivismo de los empleados públicos o del juego de poderosos grupos organizados. Es necesario uque se promueva la promulgación de buevas leyes y la formacion de instituciones adoptadas a los tiempos\%, dejando a un lado las frases hueras y las palabras engañosas, para que la generalidad de los hombres se sientar apoyados y sostenidos en sus legintnas exigencias y esperanzas.

Paralelamente a esta labor kes necesario formar una opinoto publica que, sin buscar el escándalo, señate con franqueza y valor las personas y las circunstancias que no se conforman con las leyes e instituciones justas o que deslealmente ocultan 12 realidad». «Para formar esta opinion púbica no basw ta poner en mano de los ciudadanos una papeleta de voto u otros medios semejantes, es necesario formar a los hombres, darles medios para acrecentar sus energias internas y la ferviente voluntad de contribuir a influir, con wna sana moral, en todo el orden públicos ( $1-V-1955)$. We ahí la tarea de las asom ciaciones cristianas de trabajadores a este respecto.

Lo doctrinal coincide totalmente con la realidad. Muestra de ello la hallamos en la declaración de principios publicada por la JOAC en su Boletín de 1 de marzo de 1956:

1) La JOAC tiene como fin formar jóvenes obreros cristianos y lanzarles a la acción apostólica missionera por la recristianización de la masa trabajadora. En cuanto organización de la lglesia nunca puede intervenir en ana scción politica.

2) La misión de la JOAC dice relación con la extensión del Cuerpo Mistico, el reinado social de Jesucristo y la evangelización de los ambientes de vida, lo cual, sin invadir ningun campo extraño, sino descle su misna función santificadora, deberá denunciar la injusticia, el pecado individual y com lectivo, y el error en codas sus formas, dando con ello un cristiano testimom nio de Verdad y Amor.

3) La JOAC, que trabaja con hombres concretos, de aquí y ahora, som bre los que pesa la doble responsabilidad de sus deberes cristianos y ciudadanos, se preocupa de dar a sus miembros la luz y la fuerza necesarias para que puedan vivir en cristiano sus tareas temporales dentro de las estructuras políticas, sociales, sindicales, económicas...

Si en cuanto Organización tiene que estar siempre al margen de toda política, forma, en cambio, a sus militantes y adheridos para que cada wno de ellos, incorporado libremente a cualquera de los varios programas que el

2 Segunda adicion, pán. 326. 
amplio campo de los principios católicos permite, pueda realizar en cristiano los deberes que su vocación temporal le impone.

4) Y les hace ver que el cumplimiento de los mismos grava su conciencia de modo que, en cuanto cristianos que son, miembros de la Iglesia, están obligados muy seriamente a no desertar de los catopos polínicos y social en cualquiera de sus formas. Más aún: a trobajar positivamente en ellos como una exigencia, incluso, de su condición sobrematural.*

\section{Relaciones con lo temporal}

Di apartado 2) nos introduce en una dificultad que puede presentarse: La acción apostólica zedebe desentenderse de lo temporall Pio XrI nos dice que wel amor hace latir sus corazones, el mismo anor que hizo latir el corazón de Cristo, la solicitud por la defensa y respeto de la dignidad del trabajador moderno y el celo activo para ponerle en condiciones de vida material y social en armonía con tal dignidad» (1-V-1956). Luego la preocupación por lo material entra dentro de la misión de las asociaciones cristianas de trabajadores.

Leemos en un Editorial de «Ecclesias (25-VHII-1951): «BI apostolado católico del obrero por el obrero no puede realizarse desentendiéndose de la cuestión social, haciéndose cómplice, siquiera sea con el silencio, de las injusticias sociales, desconociendo las necesidades materiales de los trabajadores, invitándoles tan sólo a levantar la vista al cielo para que no reparen en sus manos vacías». No hay que llevar a Cristo a la masa trabajadora ni por la fuerza ni por el engaño, sino por la convicción y el amor. Seráa engaño el atender al alma olvidando el cuerpo. Querer llevar a Cristo a la masa trabajadora velando las injusticias sociales sería hacer realidad la frase marxista de que «la religión es el opio del pueblo». Poner de manifiesto estas injusticias, preparar a los hombres que sepan reconocerlas y remediarlas en lo que esté en su mano, no es invadir campos ajenos. Las asociaciones cristianas de trabajadores son asociaciones humano-apostólicas, y por tanto persiguen fines bumano-apostólicos con medios proporcionados.

«La Iglesia no se limita a invocar este orden social más justo, sino que indica también sus principios fundamentales, exhortando a gobernantes, legisladores, patronos y directores de empresa a ponerlos en práctica (1-V. 1955). Por lo tanto, la Iglesia y sus asociaciones no pueden quedarse en el terreno de los puros principios, pueden y deben pasar a convertirlos en operantes, sin que esta actuación sea en menoscabo de su misión divina o traspase los límites de su actuación en bien de las almas. Poner de manifiesto las injusticias de la sociedad con espíritu de crítica constructiva es labor muy propia de un cristianismo auténtico. El Evangelio está lleno de ejemplos semejantes, ya por boca del Precursor, ya del mismo Divino Maestro. 


\section{Relaciones con el Mouminto Obrero}

Mons. Ancel defwe Mol Momicno Obrero cono da participacion de la

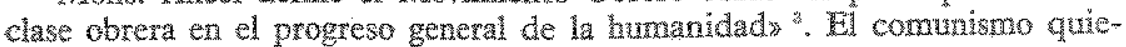
re conducir este movimitento obrero, pero en realidad zo es más que unc parte del mismo. El cristianismo también tiene su puesto de honor. Lot obreros belgas ban sido los que han organizado mejor al mowimianto obreto dentro del campo católico: ha sido uno de los grandes frusos reportados por la JOC, que preparó a los hombres que hicieron posible la hermosa realidad del MOC.

Dentro del movimianto obrero se halata, pues, el comunismo y el crism rianismo. Ambos se disputan la dirección del mismo «Los tratoladores cristianos, impulsados por los eternos principion y sacando de la fe y de la grat cia la suave fuerza necesaria para superar los obstáculos, no están quizá lejos del día en que podrán ejercitar el oficio de guas en medo del mundo del trabajo. ¿Y por quf́n no? La doctrina sana que profesan, los rectos sentimien. tos que los animan son otros tantos titulos legitimos para llegar a ser los guas del movimiento obrero en la actualidad» (1-V-1956).

El movimiento obrero se propone fines económicos y contingentes, pero aun así, ligados intimamente con destino sobrenatural del hombre con su conjunto de derechos y deberes naturales de los que no se puede prescindir. La Internacional comunista, nacida como autoderensa ante las injustcias capitales, prescinde de los valores espirituales e intenta sostener el movimiento obraro sobre la base movediza de lo contingente. Las asociaciones cristianas de trabajadores son las que deben fundamentar el movimiento obrero. No han nacido para fracturarlo, sino para robustecerlo; prueba de ello está en que uestán dispuestas a abrir las puertas a todos, animadas del deseo de establecer contactos cada vez más amplios con aquellos que pertenecen al mundo del trabajo, más para dar que para recibir» (1-V-1956). Muestras elocuentes de ello han sido la extensión a todos de la Fiesta del Trabajo, y la concentración milanesa del último 1 de mayo en la que hallábanse representaciones de diversos países. Sobre la unidad internacional imaginaria de la clase obrera, las asociaciones cristianas de trabajadores presentan ahora la unidad perenne del cristianismo. «Quienes se simuieren intranquilos sobre el indiscutible fundamento de vuestra unidad, que no ha sido superada por ningún desarrollo histórico, no son aptos para capitanear las ACLI en su misión de ser fermento, en el sentido evangélico, bara el mundo obreros (1-V-1956).

Las asociaciones cristianas de trabajadores, unidas a otras organizaciom nes obreras que de alguna manera admiten los principios cristianos, constituyen el Movimiento Obrero Cristiano, que a su vez forma parte del movi-

\& El Movimiento Obrero. Mons. ANcel. Publicaciones «ưnque», núm. 3. 
miento obrero general, en el que tarabién participan otras ideologías. Si queremos que este Movimiento Obrero Cristiano no se vea absorbido, antes low gre absorber las mentalidades erroneas, es necesario que el Cristianismo se viva integramente, que trascienda a las estructuras todas del mundo actual, sin olvidar las económicas. El Movimiento Obrero Cristiano triunfará si demuestra que no es sólo una forma de pensar, sino también una forma de vida que se vive no sólo en el campo obrero, sino que trasciende a todas las clases sociales. De ahí la necesidad de pensar en un nuevo orden social.

\section{Ante un nuevo orden social}

El Papa examina un nuevo aspecto. ¿Qué parte tendrán las Asociaciones Cristianas de Trabajadores en el establecimiento de un muevo orden social? "Ha llegado el momento de abandonar las frases vacías y de pensar con la "Quadragesimo annos en una nueva ordenación de las fuerzas productivas del pueblo..., que se convierta en el fundamento de un orden econónico mejor, de una sana y justa autonomía, y abra a las clases trabajadoras el camino para adquixir su parte de responsabilidd en la conducción de la economía nacionals. "Crear este sentido de solidaridad, segura garantía de rectitud y paz social, reside en el espíritu del Evangelio y afluye hacia vosotros del corazón del Hombre-Dios, salvador del mundos (11-III-1945). En estas frases está latente la idea de la organización profesional de la sociedad. el Corporativismo. El que nace espontáneamente del pueblo es el mejor, pero también el más difícil de llevar a la práctica, ya que supone mucha cultura, mucho sentido del prójimo, lucha constante contra el egoismo. Si se quiere pensar en hacer realidad este deseo pontificio de organizar profesionalmente la sociedad, de crear una auténtica democracia orgánica, utilizando incluso como base, si se cree oportuno, instituciones ya existentes, se requiere ir pre-
parando los hombres, la mentalidad de las generaciones. El régimen corpora-
tivo es incompatible tivo es incompatible con la incultura, con el individualismo. Buena tarea a desarrollar por las asociaciones cristianas de trabajadores. Para inculcar este espiritu y hacer realidad una sociedad que lo viva es necesaria la formación
de la clase trabajadora.

\section{Formación de la clase obrera}

uLa formación religiosa del cristiano, y en especial del trabajador, es uno de los principales oficios de la acción pastoral moderna». «La verdadera y profunda instrucción de los adultos es una necesidad de primer orden». Si la clase trabajadora se halla necesitada de cultura en general, ciertamente que todavía se halla más necesitada de cultura religiosa. Insiste Pí XII en la necesidad de una formación metódica, atractiva y siempre adaptada a las circunstancias locales, evitando que se vea entorpecida por las ambiciones particulares o las rivalidades entre grupos particulares (1-V - 1955).

El punto central de formación obrera en el método jocista, seguido actual- 
mente por la mayoría de las organizaciones apostólicas, radica en las en cuestas tripartias del per, juggar y actuar, que consiguen alejar por una parte el inconsciente optimismo, que prescinde totalmente de la realdad, $y$ por otra, la tendencia todavia menos apostolica a un pesimismo perezoso $y$ deprimente. Complemento de las encuestas son las urevisiones de vidas, auténtico «Capítulo» o Ejercicio de faltas» de nuestros militantes obreros, que evitan así la palabrería, los propósitos incumplidos, el aburguesamiento, y labran en su alma virtudes tan sociales como la sinceridad y la generosidad. A través de sus uplanes cíclicos» se va formando el militante hasta poder lanzarlo de lleno a la conquista de la masa trabajadora para Cristo y de un sano bienestar para rodos.

Se procura thfundir en el alma del trabajador un profundo sentido sobrenatural de hijo de Dios, un alto aprecio de su condición obrera, un sentix hondamente, con toda su fuerza, la dignidad de la persona lumana que lleve consigo el respeto de sí misno y de los demás. Un mitzutate católico obrero se presenta a sí mismo: wObrero peón de Alos Homos, por la gracia de Dios....

La formación que se da a los militantes de estas asociaciones es una form mación activa: ellos son los que las dirigen, los que las llevan adelante defendiéndolas de las malas inteligencias, haciéndolas prosperar a costa de hom ras de reposo y de hacer más austera su vida... La clase trabajadora pide responsabilidades en la hora actual: la Iglesia apoya esta justa pretensión. Las asociaciones cristianas de trabajadores preparan a sus horabres responsabilizándolos ya desde el primer momento: son una escuela activa.

Toda la formación del militante obrero católico lleva wn sello caracteríscico: la orientación hacia su vida obrera. Hay que hablarles de Dios, pero con vistas a su persona, a su vida, a sus responsabilidades... Hay que formarles hablándoles de sus problemas, de hacerles vivir su formación religio sa, social, apostólica... Mejor todavía, ellos mismos en «equipo» se ayudat mutuamente, se suscitan amistades sobrenaturales, apostólicas, misioneras... Aprenden a amarse, a defenderse, a hacerse bien unos a otros... Con la fuer za del espíritu, del corazón, del amor a Cristo van a la conquista del mundo.

\section{Mistica Obrera Cristiana}

Su formación sobrenatural, su cristianismo ka los primeros siglos», les hace vivir intensamente una mística que contrasta con el materialismo de la hora actual. La mística marxista se combate infundiendo mística cristiana en el alma de nuestros trabajadores. A las demás clases sociales toca ser consecuentes con esta formación: el militante obrero desprecia los actos externos si no nacen de lo interno. Cuando ve la exuberancia de actos piadosos en otras esferas sociales, y el poco eco que tienen en la fidelidad de una vida honrada, siente hervir su sangre muy justificadamente, siente nna terrible lucha entre su espiritu cristiano de amor a todos, y su sentimiento de justicia y sinceridad, y con los resabios de un pasado de odio, de promesas 
incumplidas, tiene que hacerse violencia para ahogar los brotes de una lucha de clases, que de estallar de nuevo quizh el menos culpable seria él mismo.

\section{¿Cofradias?}

El militante obrero, que vive la mística cristiana, se entusiasma por Cristo y se entrega a una vida sobrenatural intensa, pero en ningún modo desligada del apostolado directo. Con todo, no son raras las asociaciones obreras cristianas cuya raisión se encamina sólo al individuo, al perfeccionamiento espiritual de sus triembros, al culto divino. Es el caso de las cofradias, tan exsendidas en algunas regiones españolas, es también el caso de asociaciones apostólicas que se han estancado en un estadio pietista, o a lo sumo mantienen cierto apostolado paternal con clases todavia más inferiores: proletariado de suburbios generalmente, pero que no realizan directamerte ningún apos-
rolado horizonatal.

Indudablemente que tal modo de proceder es bueno y no hay razbia alm guna para impedir la creación y desarrollo de tales asociaciones, cuyos fines son excelentes. En cierto modo corresponden a los religiosos de vida contemplativa o dedicados al culto divino, tan necesarios en nuestra sociedad materializada. Sin embargo, salvo vocaciones muy claras y especificas y dignas de todo encomio, los tiempos actuales piden también militantes que actúen como fermento en la masa. La fermentación no se alcanzará sin oración y penitencia, pero es cierto que Dios Nuestro Señor no suele actuar directamente, sino que suele emplear las causas segundas, y éstas, hoy, son el apostolado del obrero por el obrero. Es, por lo tanto, del todo necesario que el militante obrero esté bien formado, que sepa actuar, que sapa dar el testimonio vivo de su fe, que sepa resistir los embates del egósmo y del materialismo. Esta es la tarea de las asociaciones de carácter apostólico.

Desviar vocaciones contemplativas sería hacernos cómplices del materia lismo. Obligar a la clase trabajadora a ser sólo "contemplativa», a organizarse sólo en cofradias, sería desear mantener una «capitisdiminutio» que clama al cielo, o por lo menos sería no tener conciencia de la realidad social de la segunda mital del siglo XX.

\section{EPILOGO}

«La primera y más importante lección que debe proclamarse - dice San Pío $\mathrm{X}$-, es que siempre, al lado de los sindicatos, existan también asociamciones encargadas de dar a sus miembros una sólida formación religiosa y moral, a fin de que éstas infundan a su vez en las organizaciones sindicales el buen espíritu que debe animat toda su actividad. Así acaecerá que estas asociaciones ejercerán una influencia que traspase el estrecho círculo de sus miembros» ("Singulari Quadam», 24-IX-1912). Pío XII añade deben tender wa la formación de trabajadores eminentemente cristianos, que siendo igualmente excelentes por su capacidad en el ejercicio de su arte y por su 
profundidad religiosa, sepan armonizar la lirme tutela de los intereses ecom nómicos con el más estricto sertido de la justicia y con el sincero propósito de colbowar con las demis clases sociales en la renovación cristiana de roda la vida socinls (29-VII-4948).

Las asociaciones cristianax de trabaiadores son las encargadas de evangem lizar el mundo obrero, de extender en la clase krabajadora los frutos de la Redencion. Todos los hombres han sido redimidos por Jesucristo: todos sim excepcion. han de ser evangelizados. La respuesta al liamamiento divino es en sínisma estrictamente persona, pero el ambiente influye profundamente en la respuesta personal del hombre. De ah la importancia de la evangelzam ción en el propio ambiente, del apostolado del obrero por el obrero. Los obreros individualmente, y con mayor efectidida asociados, son los pritmem ros y principales apóstoles de sus compañaros de trabajo, pero no los únicos" a esta labor evangelizadora estan llamadas todas las clases de la sociedad.

En priner lugin los secerdotes, que dejando si es preciso, a ejerrylo del Divino Maestro, las nowerta y nueve ovejas, vayan en busca de la que se descarrió. Después los religiosos y seglares, cada uno segun sus posibilidam des, achando en toda su vida de forma gue su conducta no aparte a los tram bajadores de la Iglesia: como si tuviera que ser juzgada no solo ante el tra bunal de Dios, sino también ante el tribunal de quienes diaramente suirem el peso de la injusticia, la incomprension, la humillación... El ejemplo de vida cristana de las clases pudientes y dirigentes es una predicacion eficachsima y una acción social muy beneficiosa. Cumplimiento de la doctrina som cial de la Iglesia en las empresas, faciltando a los trabajadores el que puejan realmente aumentar su cultura. No imponer a la clase trabajadora lo que conviene $y$ da buenos frutos en otras esferas: acomodarse a su matera peculiar de ser. Saber comprender a muestros hermanos. He ahí ampla tarea para quienes queremos ser auténeticos seguidores de Cristo en el siglo actual...

Las asociaciones cristianas te trabajadores son la presencia de la Iglesia en el ambiente obrero. A su vez son la presencia de la clase trabajadora en la Iglesia. Un día no lejano lograrán cristianizar el mundo del trabajador.

Luis Antonio SOBREROCA, S. I. 


\section{FORMACION DE DIRIGENTES SINDICALES EN EE. UU.}

SUMARTo: Situación económico-social del obrero en EE. UU.; el salario; legislacion social; su eficiencia pora la elimanación del elemento comunista; buena fe de los patronos y protección oficial. Las huelgas en los EE. UU. Sindicatos: su proceso, su eficacia; su prestigio y numero de inscritos; formación de los dirigentes; selecta y práctica.-Educación obreras educación sindical.--Origen del movi miento católico, ealucación sindical católica,-Desarrollo histórico.-Instituciones diocesanas; motivos de su desaparición.-Instituciones de religiosos. Masa frente a selección.-Academicismo frente a estilo popular; Instituto Xavier de New York y la Academia León XIII, etc.-Educacion de adultos frente a estudios graduados.Formación técnica y moral frente a formación apastólica. Dos formas de difundir el buen espiritu: como miembro de la junta directiva del Sindicato y siendo modeto de rectitud.-Resumen de la uctuación católica; formación social en general; de la masa; de dirigentes: en técnica, en religión.-Actividades no católicas; Colegios 3 Unidersidades; cursos de materias técnicas para dirigentes sindicales.--Crinicas de? sistema católico; personalismo excestoo; no hacer uso de los medios oudio-tisuales; falta educación activa-necomendaciones Pontificias; la Iglesta no se opone a los métodos pedagógicos modernos; la Iglesia aprueba y recomienda la enseñanza activa; testimonios de S. S. el Papa Pío XII.

Estados Unidos aparece ante el mundo entero como un país admirable por su progreso técnico y por el éxito obtenido en asuños económicos y finnancieros.

Economistas y políticos de otras naciones estudian con interés creciente los métodos estadounidenses, esperando hallar posibilidades de adaptación de tales métodos a sus respectivos países. Desafortunadamente, los mencionados observadores descuidan el analizar la clase de substrato social, indispensable para tal florecimiento económico. Dicho substrato consiste en el bienestar económico y sccial disfrutado por los obreros norteamericanos.

Sin este bienestar, Estados Unidos no sería lo que hoy es. Póngase a los abreros norteamenicanos un salario semejante al de los obreros de Suramérica, por ejemplo, y pronto se derumbaría todo estropitosamente. Veámoslo: los obreros habrian de cambiar por una modesta bicicleta el lujoso automó- 
vil en que hoy se dirigen al taller; a consecuencia de ello, la General Motors y demás Casas productoras de Detroit y sus alrededores habrian de cerrarse en su mayor parte, al no contar ya con esos treinta millones de obreros, clientes suyos.

Los obreros ya no podrían adquirir los dos o tres trajes al año que ahora acostumbran; por tanto, las tres cuartas partes de las industrias de Nueva York, productoras del vestido en serie, a precios populares, se arruinarian.

La racion alimenticia del obreto y su familia se teduciría a un minimo, con lo cual los ganaderos del Oeste y los hacendados del Centro y Sur no hallarín mercado para sus productos. Ni tampoco lo hallarian las industrias productoras de refrigeradoras, aparatos de radio y otras muchas comodidades relativamente superfluas...

El descontento cundiria entre la masa obrera, y la producción por trabajohora bajaria en calidad y cantidad...

En EE. UU. es un axioma indiscurible el que la base del progreso económico consiste en una distribución equitativa de la producción nacional, por medio de altos salarios reales. Como ejemplo de lo que un salario real significa, tenemos que en EE. UU. el salario de un día es más que suficiente para adquirir un buen par de zapatos; y la mitad del salario semanal basta para un traje excelente; mientras tanto, en los países suramericanos los obreros necesitan el jornal de tres o cuatro dias para comprar sus zapatos, y el de dos o tres semanas para el traje.

Ahora bien, ¿cómo han sido posibles en EE. UU. tan altos salarios reales? Para meior comprender el problema se han de tener en cuenta varios datos: por una parte, existe una buena legislación social, puesta en vigor por medio de eficaces organismos, tales como la N. L. R. B. (Junta Nacional de Relaciones Obrero-Patronales). Esta Junta presupone, en la práctica, que los patronos antisociales son tan enemigos del régimen como los más furibundos comunistas. De hecho, éstos encuentran sus mejores, aunque inconscientes, colaboradores en aquellos patronos que, con sus arbitrariedades e incomprensiones, fomentan el odio de clases. Y por eso la NLRB, sin miramiento, carga la mano a los patronos que se niegan a tratar «in bona fide» con las organizaciones sindicales.

Respecto a los comunistas, aunque su existencia está legalmente permitida, son excluídos de las Directivas de los Sindicatos de wn modo muy sencillo: cualquiera puede formar un Sindicato, o ser elegido miembro de la Directiva, incluso los comunistas. Pero aquí, dada la mentalidad práctica yanki, un Sindicato no consigue mantener sus afiliados a no ser que muestre su eficacia parlamentando con los patronos y consiguiendo mejoras satisfactorias. Los patronos pueden negarse a parlamentar con el Sindicato hasta que éste llene ciertos requisitos y sea reconocido por la NLRB; ésta, a su vez, exige que los Directivos afirmen por escrito, bajo juramento, que no son ni han sido comunistas. Si se prueba que han jurado en falso (y la Policía es en esto muy eficaz), la sentencia consiste en multa y ocho años de cárcel. Si no quieren prestar tal juramento, o abandonan la Directiva (y así 
el Sindicato queda himpio de comunistas), o si no la abandonan el Sindicato no es reconocido, no puede conseguir mejoras, desaparece.

Supuestas la exclusión de dirigentes comunistas, la buena fe por parte de los patronos y la protección oficial, fácilmente se llevan a cabo los contratos colectivos y se van renovando cada año, con razonables mejoras en los salarios y condiciones de trabajo. Esto no excluye el que a veces se llegue a prom ducir la huelga; pero ésta carece del carácter trágico de los países europeos. Aquí la huelga, ordinariamente, es un proceso normal y pacífico, por el cual ambas partes, a medida que pasan los dís y se notan las respectivas périd. das monetarias, tónanse más razonables y acaban por convenir en un justo medio.

La ley prohibe a los huelguistas el reunirse en gran número frente a la fábrica o lugar de trabajo; por tanto, solo una media docena de hulguistas se dedican a pasear a la entrada, con grandes carteles en gue anuncian con moderadas frases la huelga. Son relevados cada cuatro horas, dia y noche, de modo que nunca falte la wlínea del piqnete». Esta linea imaginaria que se atraviesa a la puerta, tiene un valor psicológico enorme: los huelguistas no necesitan hacer violencia para que nadie entre; de hecho prefieren que entre alguno que otro, para que conste que no hay violencia. Pero ningún camión pasará, porque todos los Sindicatos del Transporte tienen en sus contratos colectivos una cláusula por la cual no pueden ser obligados a hacer entregas de material donde hay una klínea del piquete». Y si son empleados de un comercio los que están en huelga, entonces la mayor parte de los clientes se abstendrán también de romper esa línea sagrada...

Otro de los factores que se han de tener en cuenta es el elevado número de obreros afiliados a los Sindicatos. La Central Sindical A. F. L.C. 1. O. cuenta con cerca de 16 millones. En algunas industrias, tales como la Siderurgia, Metalurgia, Topografía, Electricidad, etc., más del 80 por 100 de los obreros y empleados pertenecen al Sindicato respectivo, y siguen disciplinadamente las ordenes de sus dirigentes. $Y$ con esto llegamos a la más importante causa del bienestar obrero: sus jefes sindicales, generalmente aptos, eficaces, dotados de experiencia, honradez y prestigio.

Los viejos lideres se fueron fraguando a golpes de martillo, en el yunque de los Gobiernos económico-liberales de principios de siglo, que negaban el derecho de asociación sindical y perseguian como malhechores a los organizadores sindicales. Y cuanto más violenta era la oposición de gobernantes y patronos, tanto más violentos se tornaban los dirigentes sindicales, hasta el punto de que muchos de ellos acababan en comunistas o anarquistas.

Hoy día, obreros y patronos tratan zazonablemente sus diferencias en una atmósfera de comprensión y respeto mutuos (si exceptuamos el Sur, todavía en vías de industrialización y con prejuicios y prácticas antisindicales), Casi todos los dirigentes sindicales jóvenes terminaron su Bachillerato, y algunos incluso uno o dos años de Universidad, antes de ir al taller. $Y$, además, por uno o dos años, o al menos durante algunas semanas en verano, asistieron 
a cursos de capacitación sindical, en alguna Escuela laboral, Universidad o Instituto de Relaciones Obrero-Patronales.

Por tanto, no es de extrañar el que, como se está repitiendo en revistas sociológicas americanas, «los dirigentes sindicales estadounidenses actuan como hombres de negocios y se expresan como social-cristianos, y en comportamiento nada tienen de marxistas».

Veamos qué clase de formación es esa que han recibido en las Escuelas laborales, Institutos o Universidades.

\section{Educación abreta}

En EE. UU. se entiende por Educación Obrera «toda enseñanza o entrenamiento que prepare a los obreros para conseguir por sí mismos sus mejoras como grupos.

«Enseñanza o entrenamiento», ya que no se circunscribe a la mera instrucción teórica, sino que abarca ejercicios prácticos, tales como el adoptar decisiones, tras ordenada discusión en mesa redonda; el uso del micrófono, editar hojas en mimeógrafo, escribir articulos periodísticos, dirigir asambleas, etc.

«que prepare... para conseguir por sí mismos»: es una educación directamente encaminada a que el alumno se acostumbre a asumir responsabilidades y a llevar a efecto los planes acordados.

umejoras», en general, sin limitarse a las meramente monetarias.

«como grupo»: con esto se excluye otras especies de educación dadas a obreros, tales como el enseñarles a leer y escribir, o el facilitarles el aprendizaje de un oficio, ya que en ambos casos se trata de mejoras que han de beneficiarles «como individuos particulares» (los obreros que aprenden un oficio consiguen mejores salarios para sí mismos, mientras que los dirigentes sindicales que consiguen un buen contrato colectivo consiguen mejores salarios para todo el Sindicato).

Tomaremos primeramente las actividades de educación obrera (para evitar confusiones llamémosla Educación sindical) ejercidas por los católicos: después pasaremos a los no católicos, entre los que descuellan los mismos Sindicatos y algunas Universidades.

\section{Origen del movimiento católico}

Las actividades educativas sindicales entre los católicos estadounidenses tienen su origen en la encíclica "Quadragesimo Anno», núm. 35, donde S. S. Pío XI, al tratar de los Sindicatos neutros en países de minoría católica, desarrolla lo ya propuesto por S. Pío X en la «Singulari Quadam», recomendando que «siempre, junto a esos Sindicatos, deben existir otras agrupaciones que se dediquen a dar a sus miembros una seria formación religiosa y moral, a fin de que ellos, a su vez, infundan en las organizaciones sindicales el buen espíritu que debe animar toda su actividad». 
La finalidad inmediata de dichas agrupaciones está bien definida: «dar... tormación religiosa y moral». Ahora bien, esta formación religiosa y moral no se ha de limitar a perfeccionamiento privado de dichos miembros - labor que más bien correspondería a sus respectivos párrocos-, sino que está dirigida a un fin ulterior, ya que Pio XI añade: «a fin de que ellos, a su vez, infundan en las organizaciones sindicales el buen espiritu que debe animar toda su actividad». Este kinfundir el buen espiritu» es, pues, una especie concreta de apostolado. Si se tratara de un pás católico, corno cualquiera de las naciones suramericanas, por ejemplo, este apostolado tendría como fin el que los afiliados al Sindicato —en su mayoria católicos, al menos de nombre- - procedieran en sus actividades sindicales como verdaderos católicos prácticos, de acuerdo con las encíclicas, como lo da a entender Pio XI en otra parte de la misma encíclica (núms, 143-144). Ern cambio, en el punto que estamos tratando, puesto que el Papa se refiere a paises de trinoría católica, evidentemente no pretende que dichos apóstołes obreros se dediquen a una especie de proselitismo cátólico, para que los afiliados al Sindicato se conviertan a nuestra Religión, no: se trata, sencillamente, de promover la armonía que debe reinar entre las clases sociales según lo exige la recta razón; de estimular la honradez y justicia basada en la ética natural, y la fraternidad universal que en todo ser humano ha sido grabada por la ley natural.

Todo esto, en nosotros, los católicos, va motivado por la caridad cristiam na y las enseñanzas evangélicas. Para los no católicos, la motivación será otra, tal vez la filantropía, ideales humanitarios, razones prácticas, etc. Lo importante es que los obreros católicos logren infundir en las actividades del Sindicato ese buen espíritu de armonía y fraternidad, honradez y justicia; es decir, antimarxismo positivo, o constructivo. Y eso es lo que en EE. UU. ya se va logrando en gran parte.

Para implantar este antimarxismo constructivo, los catóicos atacaron el problema por varios frentes, como en seguida veremos. Por una parte, se organizaron las agrupaciones demandadas por el Papa, exclusivamente para obreros católicos. Por otra parte, se abrieron instituciones educativas sindicales, ya sea para católicos, o bien para obreros en general, prescindiendo de su religión, o para toda clase de público, sean o no obreros.

La agrupación se denominó A. C. T. U. (Asociación de Trade-Unionistas Católicos), cuyas dos ramas principales son Detroit y Nueva York. Ambas ejercieron poderosa influencia en el desalojar a los comunistas de los puestos directivos antes de 1947 en que se puso en vigor la legislación que citamos al principio de este artículo. Posteriormente, las A. C. T. U. se trabaron en dificultades tácticas y personalismos con otros dirigentes, aun católicos, de suerte que hoy dia, debido tal vez a cierto exceso de agresividad o imprudencia, son objeto de suspicacia y animadversión en los medios sindicales.

En cambio, las instituciones educativas sindicales catolicas - de labor moderada, pero más eficaz, a la larga- disfrutan de simpatia y buena aceptación. 
En el resto de este articulo nos limitaremos al estudio de estas insti tuciones.

\section{Desarrollo histónico}

Desde 1922, la Sección de Sociología de la Universidad de Loyola de Chicago había organizado una Escuela Móvi de Pensamiento Social, que recorria diversas diocesis dando conferencias sobre las enciclicas, cooperativas, justicia social, salarios, paro forzoso, etc.

En 1938, la Escuela Obrera Católica Crown Heighs, de Brooklyn, Dueva York, dingida por Padres de la Compañía de Jesús, comenzó tres cursos sociales: wno sobre el problema social en general, otro sobre relaciones obrerom patronales (en el sistema de discusiones en mesa redonda), y otro especialmente dedicado a patronos administradores de personal,

El movimento empezó a tomar gran envergadura en 1940 , cuando d Departamento de Acción Social de la organización interdiocesana National Cam tholic Welfare Conference organizo en Washington un cursillo de verano, y luego cursos regulares de invierno, en asuntos sociales, especialmente para sacerdotes, en la Universidad Católica de América. (Véase «atholic Social Actions, por el R. P. John F. Cronin, S. S. The Bruce Publishing Co. Milwaukee, 1948 , p. 85 y 181 y ss.)

\section{Instituciones diocesanas}

En la diócesis de Hartord (Conneticus) comienza en 1942 la primera Zscuela Laboral que con el tiempo habria de multiplicarse hasta llegar a diecisiete en sola esa diocesis. En otras diócesis también se abren escuelas laborales por ese mismo tiempo, y en 1946 llegan a veinte; en 1948 , achenta, y en el año siguiente sobrepasan el centenar.

Desde 1949, el número de escuelas laborales diocesanas comienza a declinar, y hoy dia la casi totalidad de ellas ha desaparecido.

Varios son los factores que se mencionan como causantes de tal desaparición: 1) Disminución del peligro de dominación comunista de los Sindicatos. 2) Competencia proveniente de los programas educacionales establecidos por los mismos Sindicatos y por varias Universidades, de que luego tram taremos. 3) La prosperidad económica y buenas relaciones obreromatronales. Los obreros ya no se sienten tan acuciados por la necesidad como para acudir a clases nocturnas, especialmente si éstas resultan demasiado aridas por la mala presentación o por 10 abstracto de sus temas. $\mathrm{Y}$, ciertanente, las clases dadas en las escuelas laborales fueron tornándose cada vez más áridas, ya que, ante la oposición y crítica -exageradas, si no falsas- de algunos industriales (según los cuales las escuelas laborales se dedicaban a «enseñar a los obreros solamente sus derechos, y no sus deberes $)$, en algunas diócesis se recargaba lo tocante a los deberes, y se mantenian en los principios generales, para no comprometerse en dar soluciones concretas a los conflictos so- 
ciales del momento. Para colmo de desaciertos, algunos teorizantes lograv ron que se forzara la adopción de programas çue explicaran minuciosamente las enciclicas a lo largo de... itres años! Pero estos programas no duraron mucho: o se reajustaron pronto a las necesidades de los asistentes, o se cerraron las clases por falta de asistencia. 4) Finalmente, en un Congreso som cial celebrado en Cleveland en 1955 para sacerdotes y sociólogos seglares se afirmó que en muchos casos las escuelas laborales diocesanas perecieron precisamente por haber realizado muy bien su cometido de desalojar a los comunistas e infundir el buen espiritu en las actividades sindicates.

\section{Unstituciones de los Religiosos}

El Clero regular también contribuyó, por su parte: franciscanos, domim raicos y agustinos también abrieron algunas escuelas; pero los que más se distinguieron, con mucho, fueron los Jesurtas, con sus 25 instituciones, que tueron llamadas Instituciones de Relaciones Industriales por dar lugar no sólo a los obreros, sino también a los patronos o administradores de personal, e incluso a los estudiantes que deseaban graduarse como peritos en Relaciones Industriales. La evolución de dichos Institutos presenta interesantes pasos. Veámoslos a grandes rasgos.

\section{Masa frente a selección}

Como ejemplo concreto -aunque no es una institución de los Religiosos- podemos presentar los informes publicados acerca de lo acaecido en las Escuelas laborales de la diócesis de Hartford: En los tres primeros años, 1a apertura de curso se anunciaba profusamente por la Prensa, Radio, hojas volantes, etc., a fin de atraer a las clases a toda variedad de personas, incluso patronos y autoridades civiles. Más tarde se comprobó que sólo perseveraban aquellos que en la actualidad ejercian algún cargo en los Sindicatos. En vista de ello, a partir de 1945 se suprimió toda propaganda y sólo enviaban invitaciones privadamente a los miembros de las Juntas directivas y delegados de taller. La educación social del público en general se limiaba al último mes, en que se tenía una serie de conferencias y actos públicos a cargo de prestigiosos oradores.

\section{Academicismo frente a estilo popular}

En el Instituto Xavier, de Nueva York, desde 1911, se mantenlan unas conferencias sobre asuntos económico-sociales. Al principio, el estilo era sencillo, acomodado a la escasa cultura de los asistentes, en su mayoria inmigrantes irlandeses e italianos. Poco a poco fueron introduciéndose capataces, administradores de personal, trabajadores sociales, abogados, etc., y los profesores fueron subiendo el tono. «Finalmente -escribe el director del Instituto, P. Carey, S. J.- resultó que las clases estaban llenas, pero no de obre- 
ros. Entonces hubo que romper la barrera académica y descender al plano sindical. Hoy día, el P. Corridan, \$. J. -el famoso apóstol de los muelles de Nueva York-, da clases de Economía y Moral moderna en el lenguaje realista de los cargadores del puerton. Mientras tanto, los abogados y demás personas cultas se reúnen en el mismo Manhatan, unos cuantos bloques más arriba, en la Academia León XIII del Colegio de San Ignacio.

En otros colegios de la Compañía de Jesús, como por ejemplo el Rockhurst, de Kansas City, se dan cursos separados, unos dias para los obreros y otros para los patronos o profesionales; pero a veces los mismos asistentes deciden finalmente reunirse una vez por semana para tratat sus diferentes puntos de vista amigablemente en mesa redonda.

El Colegio St. Peter's, de Nueva Jersey presenta una variante: la casi totalidad de sus cursos, o sea veintiocho, son en común; luego quedan tres cursos que interesan sólo a los obreros (como la historia del movimiento sindical, por ejemplo) y otros dos para personas de mayor cultura, y que, por tanto, vienen a quedar como exclusivos para patronos y profesionales.

\section{Educación de adultos frente a estudios graduados}

En la Universidad de Detroit, el P. Horne, S. J., mantuvo por varios afios unos cursos sociales para obreros, con creciente éxito. A su fallecimiento, tres profesores seglares trataron de continuar su obra, pero no acertaron a mantener el interés y la asistencia, y la obra fracasó. En vista de ello, el Rector decidió que se enseñaran esos mismos temas a los estudiantes, en un curso vespertino de la Escuela de Comercio. Pronto llegaron a contar con doscientos matriculados.

La Universidad Loyola de Chicago, es una de las más notables por sus estudios graduados en Relaciones Industriales. Sus estudiantes, antes de lograr la Licenciatura, han de cubrir 350 horas de práctica de Internado (llamado así por la semejanza con el periodo que los estudiantes de Medicina han de practicar en un hospital antes de ser doctorados). Dieciséis Empresas, siete Agencias gubernamentales y seis Sindicatos admiten en sus oficinas a los estudiantes para que practiquen por las mañanas. Por las tardes los estum diantes asisten a las clases de la Universidad. Con esto, las Empresas y los Sindicatos conocen cuáles son los estudiantes mejor dotados, y les of recen empleo para cuando se graduen. $\mathrm{Y}$, ciertamente, dicho empleo suele ser bien retribuído; en algunas Empresas, la paga más alta entre todos los directores es la del encargado de las relaciones obrero-patronales.

\section{Formación técnica y moral frente a formación apostólica.}

Dos son las formas en que un obrero formado en nuestras instituciones puede difundir uel buen espiritu» en las actividades del Sindicato:

1) Como miembro de la Junta directiva, influyendo en las decisiones que se han de tomar cada dia, en la armoniosa tramitación de los contratos 
colectivos, en las legitimas actividades de los huelguistas, etc. Para ello la formación recibida en las instituciones catolicas debe abarcar no sólo los principios generales ensenados en las enciclicas, sino tambist 14 aplicaciones prácticas y concretas de la técnica sindical. Por eso en los Institutos católicos estadounidenses se dedica una gran atenclón a las asignaturas de interés práctico, tales como «Presentación de reclamaciones», \&Tu y las Leyes de Trabajo», "Tácticas asamblésticas», «Cómo hablar en público: discursos para todas las ocasiones y aso del micrófono\%, etc. Parte de los cursos versan sobre temas que se discuten en la actulidad, tales como proyectos de leyes, el problema de la «Automatización» (automático contrô de las máminas por otras máquinas, desplazando al hombre). Los cursos sólo cubren un semestre, o une estación (unas ocho o diez clases, en Otoño, por ejemplo); después se prepara, a las inmediatas, el programa para la prónima estación, segun las necesidades intereses de los asistentes.

Los dirigentes no católicos reciben conocimientos similares en cursos dam dos en forma semejante por las Universidades y Sindicatos. Sin tales conom cimientos, el dirigente católico se hallaria en tal plano de inferioridad que no podría ejercer sino poca o ninguna influencia.

2) Supuestos estos conocimientos, el dirigente catolico puede, aderrás, adquirir una excelente formación religiosa que le capacite como modelo de rectitud y madurez entre los dirigentes y demás afiliados.

Cuanto a los católicos no cualificados para los puestos en las Juntas directivas, si al menos poseen ciertos conocimientos de las enciclicas y una sólida formación religiosa, ellos pueden también actuar como kdirigentes morales», es decir, dando buen ejemplo y consejo a sus compañeros de Sinm dicato.

Es muy de tener en cuenta esta distinción entre el dirigente meramente umoral», $y$ el dirigente principalmente «técnico» (decimos «principalmente...» porque todo católico que sea dirigente técnico ha de ejercer siempre cierta influencia moral, sin duda alguna). Si no se distingue bien entre estas dos clases de dirigentes caerímos en el error de pretender desplazar de las Directivas sindicales a comunistas expertos en técnica sinclical, para poner en su lugar a catolicos muy honrados y ejemplares, pero ineptos y destimados al fracaso, con el consiguiente daño para millares de obreros y descrédico para el Catolicismo.

En EE. UU., conseguida ya cierta influencia entre los dirigentes técnicos (varios de los dirigentes de la A. F. L. y C. I. O. eran catolicos; y el actual presidente de ambas reunidas, Meany, también lo es), ahora se esta tratando de extenderla a los mictnbros en general, Los Congresos de Acción Social celibrados estos dos últimos años han tratado primordialmente de este punto. Se han mencionado con gran alabanza las tácticas de la I. O. C. y los retiros especiales para obreros, tales como la Liga de Retiros de San José, de Boston. Esta Liga da retiros a más de un millar de obreros; los 
asistentes se distribuyen en grupos de unos 150 a lo largo del mes, y en diez meses reciben las meditaciones y pláticas de los Ejercicios ignacianos, más otras tantas conferencias de formación social y religiosa.

\section{Restmen de la actuación católica}

Las actividades católicas de educación sindical, que al principio consistan en un plan general de formación social como anticomunismo constructiwo, hoy día crecen diversificadas en las siete siguientes ramas:

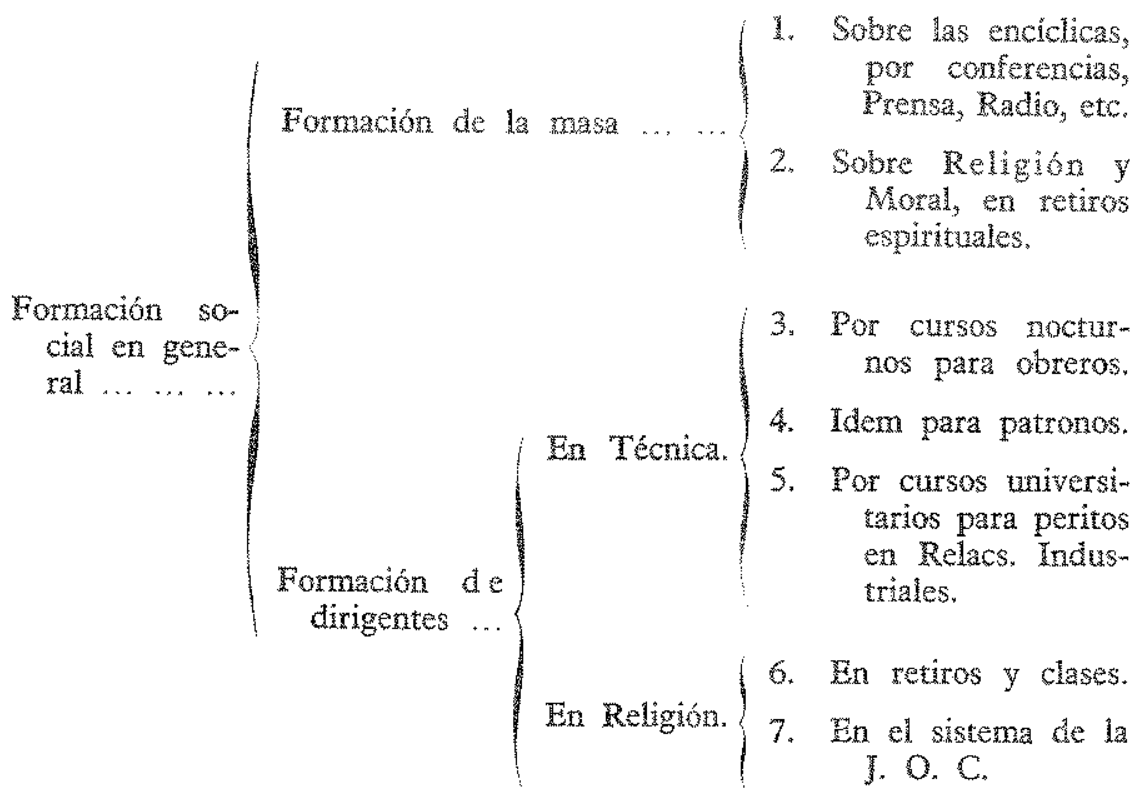

Acividades no católicas

Según una encuesta llevada científicamente en 1951, veinticinco Colegios y Universidades no católicas daban en aquel tiempo excelentes cursos en materias técnicas para dirigentes sindicales. A estos centros educativos se podrían añadir otros muchos que daban cursos no tan excelentes. Un elaborado análisis de los resultados de dicha encuesta fué publicado bajo el título «Workers Education at the University Level», por Irvine Kerrison, Rutgers University Press, New Brunswick, N. J., 1951.

Otro autor con amplia experiencia en educación sindical, describió minuciosamente los procedimientos de treinta y siete instituciones docentes, en su mayoria patrocinadas por los mismos Sindicatos. En sus programas toman 
parte principal abundantes materiales pedagógicos, tales como gráficos, carteles murates, películas, diapositivas, discos gramofónicos, etc., juntos con gran variedad de recursos didácticos modernos: discusiones en grupos y subgrupos, representaciones y otras variedades de la enseñanza activa (véase «Unión Laadership Training», por A. A. Liveright. Harper \& Brothers, New York, 1951).

En la famosa Universidad Harvard, de Boston, se mantienen cursos diurnos de trece semanas, exclusivamente para obreros enviados por los mismos Sindicatos.

Por dos años, los representantes de ocho Universidades, junto con igual número de directores educacionales de los Sindicatos A. F. L. y C. I. O., han celebrado sesiones del Comité Educativo Interuniversitario Laboral (I. U. L. E. C.). Los resultados se publicaron, con respecto al primer año, bajo el título «Universities and Unions in Worker's Education", por Jack Barbash, Harper \& Brothers, New York, 1955.

Sesenta directores de Educación de los Sindicatos A. F. L. y C. I. O. se reunieron en noviembre de 1955 en Cleveland, con vistas a la fusión de ambas Centrales y a los futuros planes de acción. Concretaron sus aspiraciones en los siguientes puntos: formación de un programa más amplio y objetivo; abundante intercambio de materiales educativos entre Universidades y Sindicatos; solicitar ayuda para la formación de educadores sindicales; desarrollo de nuevas ideas en educación sindical, etc. Apreciaron la labor educacional de los grupos religiosos en matexias sindicales, y pidieron ayuda para hacer resaltar ante el público en general la importancia de la educación obrera, en consonancia con el carácter y envergadura del movimiento sindical americano. Adoptaron la resolución de promover la fundación de una Universidad Sindical, tomando como modelo el Instituto de Entrenamiento de Dirigentes del Sindicato del Vestido Femenino de Nueva York (I. L. G. W. U.).

Veamos una breve reseña de dicho Instituto: en él se forman cada año unos treinta jóvenes, que reciben períodos alternos de formación teórica y entrenamiento práctico, de la siguiente forma: el primer periodo es principalmente teórico, y abarca tres meses con cuatro clases diarias de hora y media - -en las que se incluyen películas o diapositivas, discusiones en mesa redonda, etc., de modo que no resulten pesadas-; en el segundo periodo, los alumnos son distribuídos en diversos Sindicatos locales, principalmente en aquellos que todavía están formándose - para que los alumnos conozcan experimentalmente los problemas de los comienzos-; el tercer periodo consiste en clases por otros tres meses el cuarto periodo, dos meses en los Sindicatos, esta vez en los locales más desarrollados, para que se familiaricen con su compleja organización; finalmente, un mes de clases y conferencias, a continuación del cual son distribuídos por todo Estados Unidos y Canadá, como propagandistas, organizadores, directores de Educación, etc.; ocupan 
puestos a sueldo - con paga muy moderada al principio, pero luego va subiendo rápidamente- nombrados por al Comité Central.

\section{Criticas del sistema católico}

Aunque los acatólicos aprecian la labor educadora sindical de la Iglesia en $E$. UU, - que sobrepasa con mucho a las actividades de los demás grupos religiosos-, no dejan por ello de notar algunas deficiencias, entre las cuam les destacan las siguientes:

1) Que las instituciones católicas con frecuencia dependen excesivamente de una sola persona; fallecida ésta, o trasladada a otra parte, perece la obra. In el libro de Kerrison arriba mencionado, su autor cita varios ejemplos, entre otros en de la Universidad de Detroit, que ya comentamos. Esta crítica tenía, ciertamente, bastante fundamento a los principios, cuando por iniciativa privada un sacerdote diocesano o religioso se lanzaba a la educación sindical, lleno de celo apostólico, pero sin apoyo económico y casi sin respaldo de ninguna clase. Se trataba, sencillamente, de una tentativa de resolver los problemas acuciantes del momento. Entre los acatolicos el problema es distinto: ellos no comienzan ninguna institución mientras no cuenten con un buen fondo financiero con que pagar tentadores salarios a los educadores; mientras subsista ese fondo, nunca faltan asalariados que tomen a su cargo la institución. El mismo autor trata varios casos de extinción por falta de fondos.

En cambio, en la actualidad, entre los católicos, visto el buen resultado de las tentativas de educación sindical, los Obispos y Superiores teligiosos dedican ordinariamente varios Padres a cada institución, de modo que puedan actuar «en equipo», y sustituirse mutuamente.

2) Que los católicos, generalmente no hacen uso de los medios audiovisuales y enseñanza activa.

Ciertamente, se comprende que un sacerdote que por siete años de su carrera, cuando menos, ha asistido a clases de Filosofia y Teología, dadas en forma abstracta y silogística, esté habituado a esa forma de pensar y expresarse y le parezca la más natural. Necesita hacerse violencia para acomodarse a la realidad, que es mucho más baja de lo que él puede calcular... Véase, por ejemplo: Según estudios realizados en el Ejército estadounidense acerca de la capacidad mental media de sus soldados -aun siendo ésta superior a la de otros ejércitos-, resulta que el 97 por 100 de la tropa $-y$, consiguientemente, también de la población civil en general- no rebasa la "potencialidad intelectual» de la edad Psicológica de doce años; es decir, que ordinariamente usan sólo imágenes y acciones concretas, mientras raramente y con dificultad son capaces de seguir un razonamiento a base de principios abstractos. Consiguientemente, una educación sindical basada en los principios generales y un tanto metafísicos, de las encíclicas, ha de re- 
sultar pesada y poco provechosa, a no ser que el educador acierte a presentarla en forma concreta y sobre cascos particulares, al alcance de la mentalidad popular.

Ahora bien, tampoco hemos de caer en el otro extremo de algunos pedagogos acatólicos, que parecen creer que por comenzar una conferencia con unas diapositivas o una historieta cualquera ya está hecho todo.

\section{Recomendaciones pontificias}

Existe en esta materia, como en todo, un punto medio, que el Papa actual, con su peculiar penetración y amplitud de miras, ha hecho resaltar ex dos alocuciones recientes:

1) La Iglesia no se opone a los métodos pedagógicos modernos: En la alocución a las delegadas de la Acción Social Católica Italiana (30 de dic. 1953; Cfr. A. A. S., 1954, vol. 46, pp. 47 y ss.), dice: «No deben ignorar, ni menos despreciar, las nuevas conquistas de la Pedagogía. Más aún, les zecomienda encarecidamente utilizar ulos resultados de las investigaciones y experiencias recientes en los campos de la educación».

2) La Iglesia aprueba y recomienda la enseñanza activa: En la alocum ción a los educadores populares de adultos (A. A. S. 1953, vol. 45, pp. 236 y ss.) el Papa hace notar que los obreros, cuando acuden a las clases nocturnas, lo hacen en un esfuerzo de superación, ya que han consumido la mayor parte de sus energías en la tarea diaria. Por tanto, el educador ha de poner por su parte cuanto sea posible para que sus enseñanzas puedan ser fácil y agradablemente asimiladas. El Papa enumera laudatoriamente los recursos ordinarios de los educadores, tales como sel modo de hablar y comporarse con los alumnos adultos, el preguntarles y dar solución a sus dificultades, el alabar su ingenio y cautivar su atención...». Pero luego añade que «se ha de entender que el educador no debe confiar solamente en sí mismo. Porque hay métodos y técnicas para la enseñanza de adultos que han dado buenos resultados. $Y$ los servicios audio-visuales han tenido gran parte en ellow.

«Además - prosigue Su Santidad-, el educador de adultos tiene que mirar hacia el futuro y hacer que el adulto participe en la conquista del conocimiento, ejercitándole en pensar por sí mismo y expresarse. Esto puede conseguirse por medio de discusiones en mesa redonda acerca de problemas concretos, y acostumbrándoles a considerar las experiencias diarias para transformarlas en una cultura viva.»

«Hay que procurar - continúa Plo XII- que el educador adulto conserve su libertad en tanto grado cuanto sea posible; pero esto no significa que se la haya de dejar aislado, de modo que llegue a rehusar su cooperación a las actividades que los solicitan.»

Así, pues, el Sumo Pontífice no deja lugar a dudas respecto al método que debemos seguir en la formación de dirigentes sindicales: no debemos 
Imitamos adar a conocer》 las enciclicas y técnicas sindicales, sino más bien untrenary en trabajo de equipo, ejecitarles en aportar ideas y experiencias, en discutinlas razonablemente, tomar decisiones, asumir responsaw bilidades y cooperar an la ejecución de las decisiones adoptadas.

Esperamos que las experiencias de las instituciones católicas de EE. UU.; junto con las recomendaciones del Romano Pontífice, proporcionen abun dante semillero de posibles adaptaciones para otros paises.

MAURO BAREENECHEA, \$. J. (Cleveland Ohio) 


\title{
Cartas a la Revista ${ }^{(1)}$
}

\author{
R. P. Director de Fomativa SOCLA:
}

Voy a aprovechar una mañana de vacacion, en mas clases del cursüllo de Som ciología nuestros estudiantes «filosolos de Loyola, para recoger en esta a modo de carta abierta mis reacciones personales ante las ideas de un artaculo del $P$. Jose M. Diez-Alegria, «El salario ante la filosotia del derechon, apareciso ex el butimo numero de FombNo SOCXAt, eneromatzo 1957.

Tengo que confesar que me ba dejado cierto sabor de boca un poco anzargo. Lo cual no quiere decir gue la causa del amargor esté objetivanexte en al aruculo rismo y que, por consiguiente, el articulo sa malo, ril mucho menos. Tambien en lo material hay naturatezas que reaccionan desagradablemente a manjates sanos.

Ex el articulo del P. Diez-Alegria, el salario ha sido citado solemnemente ante el tribunal de la Filosofía del Derecho. Y tras de haber sido tratado con no mucha consideracion, al fin ha sido casi condenado. "Esta desviacion (dice el articulista) de muestras concretas estructuras de salariado es tan enorme que apenas cabe esm perar un reajuste plenaniente confonme con las exigencias de la justicia dentro del sisteman $\Rightarrow$

Porque no me parece bastante fundada esta accitud, me voy a permitir hacer modestamente algunas advertencias.

Pero antes de entrar en materia quiero llamar la atención sobre una frase del articulo que, tal como está enunciada, wo creo suene bien en el concierto de una sana sociología. Dice así: «Pero si no queremos ir a lin puro y simple colectivisw mo estatal, cosa que no parece conforme con una recta filosofía juxidica, por lo menos en el presente estadio epocal de evolución sociológica de la Ylumanidad..... Pero les que el colectivismo estatal puro y simple puede ser conforme con una recta Xilosofía juridica en ningún estadio, ni que sea epocal ni que deje de serlo, de la evolución sociológica de la humanidad, de esta humanidad caida, privada de la hasticia original y por consiguiente concupiscente y alejada además de los linderos del paraiso? $O$ des que en esta trase se apunta la idea de un posible y lícito colectivismo estatal al modo como lo adnitieron los PP. José M. Palacio y Gafo? Pudiera ser que yo estuviese sacando punta a una frase a la que el autor no pensó en modo alguno dar tal alcance. Sin embargo, no me parece que esté de sobra la acctación hecha, no por lo que dice, sin duda relación al autor, pero sí por la rrase en sí considerada.

3 Nos ha parecido oportuno recoger en esta sección de la revista la adjunta carta del P. José M. Azpiazu, antiguo profesor de Teología eta Oża y encargado actualmente del curso de Sociología en Loyola. A flla aludimos en uno de los editoriales. 
No me explico las fobias que les han entrado a algunos antores en contra del régimen del salariado. El P. Díez-Alegría, lo hemos visto antes, casi le condena. X añade en otra parte: thay que ir a una estructuracion del Derecho Mercantil como Derecho de la empresa mercantil. Y ex esta estructuración el salariado puro ha de quedar excluidos. Recientemente también, he ofdo a alguna otra persona influyente, celosamente preocupada por la situación del obrero, calificar de uabsurdos» los conceptos de salario familiar absoluto y relativo. Dudo mucho que, con todas las acotaciones y reservas al margen que puedan acompañar a las afirmaciones anteriotes, estén observadas, con el xespeto y plenitud que se merecen y son necesarias, las advertencias de Pio XI en la Q. A. " En primer lugar, los que condenan el contrato de trabajo como injusto por naturaleza, y tratan de ssutituirlo por el contrato de sociedad, hablan un lenguaje insostenible e injurian gravemente a nuestro predecesor, ctaya encíclica no solo admite el salario, sino aur se extiende largamente explicando las normas de justicia que han de regirlos.

Sin llegar a tener que estar de acuerdo con los corifeos de la democracia tristiana exagerada, que afirmaba hace años que el régimen del salario exa injusto...; que en los tiempos actuales debia tolerarse semejante réginen como un mal necem sario, pero que la justicia pedía que con el tiempo desapareciese por completo, tes gue tenemos que afirmar, ya hoy, que todas las solicitzdes de León XIII, 侻 XI y Pío XII por mejorar el régimen del salariado están de sobra, porque ya el salario ni ajustado a las normas pontificias puede resolver en modo alguno el problema social, o porque el salario no es ya susceptible de ser justo?

No es que al 2 . Diez-Alegria condene en el terreno de la teoría el régimen del salariado: «Desde el punto de vista de la Filosofía del Derecho (pág. 22), es posible un régimen de salariado que esté de acuerdo con las exigencias fundamenn tales de la justician. Pero a continuación viene a decir: este régimen está yá tan lacrado que hay que sustituirlo... ¿Por qué ho reformarlo? ¿Por qué no ajustarlo a las directrices de la Iglesia? ¿Por qué no suavizarlo y completarlo?

Los metropolitanos de la Irglesia española, a cuya declaración se hace referencia en el articulo, de ninguna manera han insinuado esta sustitución, ni reclaman, ann zemotamente, ese giro pura y simplemente copernicano de que habla el P. DiezAlegria. Al contrario, siguiendo la trayectoria de los Papas, hablan del ajustamiento del salario a las exigencias de la justicia.

En primer lugar, el contrato de sociedad no es uaiversalmente aplicable, ni mucho menos. Así sucede cuando el negocio comienza sin seguridades de exito; cuando el rendimiento de la fábrica es a largo plazo y entre tanto los dispendios son enormes; cuando es menester in en una fábrica a ampliaciones o renovaciones, bien sea por competencias en el mercado o pérdida de clientes; en empresas en las que el personal es flotante por conveniencias del mismo personal, como en el ramo de construcción; en años malos, cuando la materia prima escasea y se encarece enormemente.

Para llegar a la conclusión de suprimir el salariado no es suficiente razón el advertir la miseria de muchos obreros de hoy en nuestra patria. Desgraciados y miserables, si los hay, pero precisamente porque viven en un tégimen de salario no justo. Hagamos que ese salario sea justo, que sea realidad el salario familiar absoluto dado por la empresa y realidad también el salario familiar relativo por la intervención del Estado con las aportaciones de quienes deban hacerlas, y habrá desaparecido la miseria. Claro que para esto hay que contar con una economía suficientemente fuerte; porque en una economía pobre y con renta nacional baja la cosa no tiene remedio en ningún orden de contrato. 
Hay que tener en cuenta que, en pleno periodo capitalista y en un régimen de salariado bastante distante de legat a la perfeción que le corresponda, durante los ultimos cien az̃os se calcula que los salanios reales se han triplicado aproxima aamente. Por otra parte, la jornada de trabajo se ha reducido casi a la mutad de su primitiva duración.

Es indudable tambiét que el nivel de vida en general ha subido, y no pocos obreros en España han pasado casi del cero a cifras relativanente muty apreciables en el disfrute de la vida. ¿Que todavía aspiran a más, y con mzicha razón, porque todavia la justicia pide thás paxa ellos? Pues a lograrlo. Pero jpor qué precisamente arrumbando el régimen del salariado? ¿No hay naciones, como los Estados Unidos de América, en régimen en gran parte de satariado, y ex las que casi za dejado de ser probiema el problema social?

En régimen de salariado no llegarán a ricos todos los obreros, así es; pero, auth para que liegasen a serlo vendria que it desarrollándose y aumexuchosose la rextat racional. $\mathrm{Y}$ en plan de pleno coppentivismo y de contrato de sociedad, tse aumextarian las riquezas en la proporcion suficiente, en la proporción en que se ham aumentado éstas en el régimen del salariado? Lo que sú sabemos es que an fas naciones de régimen capitalista, libertad de empresa e iniciatva privada y acumulación de grandes capitales..., son las naciones en las que el obrero distruta de más alto nivel de vida. ¿Ganarian los obreros, en general, en paz, bienes de forwna, seguridad de vida, dentro del régimen de sociedad? Eso no lo sabe nadie. Y sin seguridades absolutas, ¿para qué levantar batderas tan radicales?

Tratemos primero de realizar un régimen de salariado, ex cuanto se pueda, perícto. Para la fijación del salario, además de lo que es necesario para un salario minimo justo, exijase el que se senga en cuenta 1 a mayor o menor efectividad del trabajo puesto por el obrero, la mayor o menor prosperidad y seguridad del negocio, etc., etc.

Que esta fijación de salario la hagan conjuntamente patronos y obreros anidos corporativamente, y para eso trabajemos por llegar a la implantación de una corporación verdad, que suxja de abajo a arriba; peto, mientras tanto, que sean los sindicatos existentes los que, de cara al bien común y bajo la vigilancia del gerente del bien común que es el Estado, de acuerdo los obreros y patronos, convengan en los estatutos laborales, por ser precisamente éste uno de los fines específicos del sindicato. Téngase también presente el consejo de Plo XI de que teel contrato de trabajo se suavice además en cuanto sea posible por medio del contrato de sociedad, como ya se ha comenzado a hacer en diversas formas, con provecho no escaso de los mismos obreros y aun patronos». Para terminat, los comunistas tratan de resolver el problema social elimiando a uno de los combatientes, que es el patrono: mala solución. Ahora, en el campo opuesto, se quiere por parte de algunos eliminar el elemento asalariado. ¿Es esta la buena solución, la solución real y verdadera del problema?

Jose Maria AZPLAZU, S. J. 


\section{ESTADISTICAS SELECTAS}

Rindiendo culto a la actualidad, creemos que serí de interés para ratestros lecm tores el conocer los siguientes datos estadisticos que contienen los indices de precios de consumo en las más destacadas naciones del muzdo, a partir de 19.37, y con relacion al año 1953, que se ha elegido como tipo, asignando a sus precios el zumero 100.

Los datos están tomados del Suplemento Estadístico de la themae Internationale du Travailn, y de la misma Eevista, correspondientes ambos al numero de febrero altimo.

Dichos datos no son enteramente homogéneos, y a veces no sim refieren a todo sel país, sino á algunas de sus poblaciones más representativas; pero nos ha pareciono, en gxacia a la claridad, suprimir algunas de éstas indicaciones del original que no afectan a la verdad complexiva y orientadora de esta estadistica.

\section{INDICES DE PRECIOS DE CONSUMO}

\begin{tabular}{|c|c|c|c|c|c|c|c|}
\hline & & A F & & & & 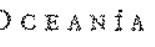 & \\
\hline & Paises & Argelia & Egipto & Tunez & Australia & $\begin{array}{l}\text { Hawai } \\
\text { (Honolulu) }\end{array}$ & $\begin{array}{l}\text { Nueva } \\
\text { Zelanda }\end{array}$ \\
\hline & 1937 & 4 & 34 & 4 & 38 & & \\
\hline & 1949 & 93 & 94 & 74 & 62 & 94 & 76 \\
\hline & 1950 & 93 & 99 & 77 & 68 & 91 & 80 \\
\hline & 1951 & 100 & 108 & 86 & 82 & 97 & 89 \\
\hline & 1952 & 101 & 107 & 97 & 96 & 99 & 96 \\
\hline & 1953 & 100 & 100 & 100 & 100 & 100 & 100 \\
\hline & 1954 & 101 & 96 & 101 & 101 & 101 & 105 \\
\hline & 1955 & 101 & 96 & 104 & 104 & 102 & 107 \\
\hline & 1956 & 104 & $\ldots$ & $\ldots$ & $\cdots$ & $\cdots$ & $\cdots$ \\
\hline 1955: & Diciembre. & 104 & 96 & 104 & $\ldots$ & 103 & $\cdots$ \\
\hline $1956:$ & Enero. & 102 & 96 & 105 & 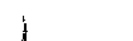 & & \\
\hline & Febrero. & 104 & 96 & 109 & 107 & & 109 \\
\hline & Marzo. & 105 & 97 & 110 & & 103 & mon \\
\hline & Abril. & 104 & 97 & 112 & & $\ldots$ & 1 \\
\hline & Mayo. & 104 & 97 & 112 & 109 & $\ldots$ & 110 \\
\hline & Juxio. & 102 & 97 & 111 & & 103 & I \\
\hline & Julio. & 304 & 97 & 109 & & $\ldots$ & 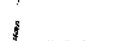 \\
\hline & Agosio, & 303 & 98 & 108 & 113 & 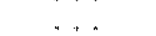 & 112 \\
\hline & Septiembre. & 104 & 99 & 108 & & 104 & \\
\hline & Octubre & 105 & 100 & 108 & & $\cdots$ & 1 \\
\hline & Noviembre, & 105 & $\ldots$ & $\cdots$ & $\cdots$ & $\cdots$ & $\cdots$ \\
\hline & Diciembre. & 105 & $\cdots$ & $\cdots$ & & $\cdots$ & \\
\hline
\end{tabular}




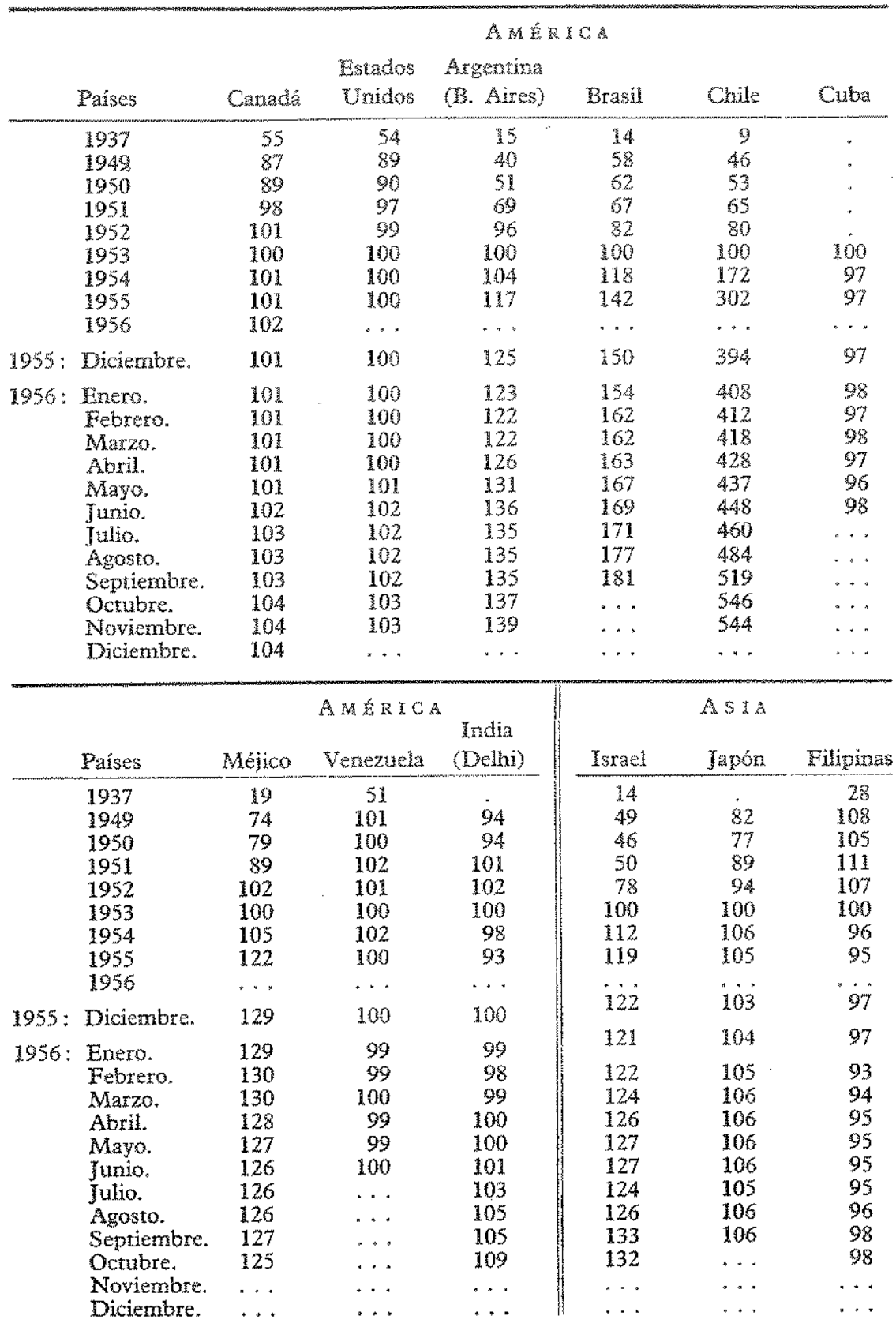




\begin{tabular}{|c|c|c|c|c|c|c|c|}
\hline & \multirow[b]{2}{*}{ Pánges } & \multicolumn{6}{|c|}{$\mathrm{ESO}$} \\
\hline & & Alemartis & Austria & Dégica & Espara & 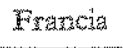 & Grecia \\
\hline & 1937 & 59 & 15 & \multicolumn{2}{|c|}{$24 \quad$ (1939) 27} & 4 & 0,3 \\
\hline & 1949 & 99 & 61 & \multicolumn{2}{|c|}{$92 \quad 83$} & 70 & 72 \\
\hline & 1950 & 93 & 70 & \multicolumn{2}{|c|}{$91 \quad 92$} & 77 & 78 \\
\hline & 1951 & 100 & 89 & 99 & 100 & 91 & 87 \\
\hline & 1952 & 102 & 102 & 100 & 98 & $10 \pm$ & 92 \\
\hline & 1953 & 100 & 100 & 100 & 100 & 300 & 100 \\
\hline & 1954 & 100 & 103 & \multirow{2}{*}{$\begin{array}{l}101 \\
101\end{array}$} & 101 & 100 & 115 \\
\hline & 1955 & 102 & 105 & & 305 & 101 & 122 \\
\hline & 1956 & $\cdots$ & $\cdots$ & $10 \%$ & $\cdots$ & $\cdots$ & $\cdots$ \\
\hline $1955:$ & Diciembre, & 304 & 107 & 102 & 107 & 102 & 125 \\
\hline 1956: & Enero. & 104 & 107 & 102 & 108 & 302 & 125 \\
\hline & Febrero. & 104 & 107 & 102 & 109 & 303 & 126 \\
\hline & Marzo. & 105 & 107 & 103 & 110 & 103 & 126 \\
\hline & Abril. & 105 & 107 & 103 & 111 & 103 & 127 \\
\hline & Mayo. & 105 & 107 & 103 & 112 & 103 & 125 \\
\hline & Junio. & 105 & 108 & 104 & 111 & 102 & 126 \\
\hline & Jutio. & 105 & 107 & 104 & 112 & 302 & 27 \\
\hline & Agosto. & 105 & 108 & 104 & 111 & 102 & 126 \\
\hline & Septiembre. & 105 & 108 & 104 & 112 & 103 & 126 \\
\hline & Octubre. & 105 & 110 & 105 & $\ldots$ & 103 & 126 \\
\hline & Noviembre. & 106 & 111 & 105 & $\cdots$ & 103 & 126 \\
\hline & Diciembre. & $\cdots$ & $\cdots$ & 105 & $\cdots$ & $\cdots$ & $\cdots$ \\
\hline & & & & $\mathrm{Eu}$ & OPA & & \\
\hline & & & Países & & Reino & & \\
\hline & Países & Italla & Bajos & Portage & Jnido & Suiza & Turguiz \\
\hline & 1937 & 2 & 38 & & $\dot{0}$ & 59 & 26 \\
\hline & 1949 & 87 & 83 & 99 & 79 & 95 & 97 \\
\hline & 1950 & 86 & 98 & 100 & 81 & 94 & 93 \\
\hline & 1951 & 94 & 99 & 99 & 89 & 98 & 91 \\
\hline & 1.952 & 98 & 100 & 99 & 97 & 101 & 97 \\
\hline & 1953 & 100 & 100 & 100 & 100 & 100 & 100 \\
\hline & 1954 & 103 & 104 & 99 & 102 & 101 & 110 \\
\hline & 1955 & 106 & 106 & 99 & 106 & 102 & 119 \\
\hline & 1956 & $\cdots$ & $\cdots$ & $\cdots$ & $\ldots$ & 103 & $\cdots$ \\
\hline 1955: & Diciembre. & 107 & 106 & 102 & 110 & 102 & 130 \\
\hline 1956: & Enero. & 108 & 106 & 102 & 109 & 102 & 133 \\
\hline & Febrero. & 109 & 107 & 103 & 109 & 102 & 38 \\
\hline & Marzo. & 111 & 108 & 104 & 111 & 102 & 137 \\
\hline & Abril. & 111 & 107 & 103 & 112 & 102 & 138 \\
\hline & Mayo. & 112 & 107 & 101 & 112 & 103 & 138 \\
\hline & Junio. & 111 & 109 & 102 & 112 & 103 & 138 \\
\hline & Julio. & 111 & 108 & 100 & 112 & 103 & 137 \\
\hline & Agosto. & 111 & 108 & 100 & 112 & 104 & 131 \\
\hline & Septiembre. & 112 & 110 & 102 & 112 & 104 & 131 \\
\hline & Octubre. & 111 & 109 & 102 & 12 & 104 & $\cdots$ \\
\hline & Noviembre. & 111 & 109 & 104 & 313 & 304 & $\cdots$ \\
\hline & Diciembre. & $\cdots$ & $\cdots$ & $\cdots$ & $\cdots$ & 204 & $\cdots$ \\
\hline
\end{tabular}




\section{VARIACIONES ANUALES DE LOS PRECIOS DE CONSUMO EN NOVENTA PAISES, DE 1954 A 1956}

\begin{tabular}{|c|c|c|c|c|c|c|c|}
\hline \multirow{2}{*}{ PPAISES } & \multicolumn{3}{|c|}{$\begin{array}{l}\text { VARBACIONDS ANUAM } \\
\text { LES EN TANTOS } \\
\text { ROR CRENTO }\end{array}$} & \multirow{2}{*}{\multicolumn{2}{|c|}{ PRISES }} & \multicolumn{2}{|c|}{$\begin{array}{l}\text { VARIACEONES ANUA- } \\
\text { LES EN TANTOS } \\
\text { POER CIENTO }\end{array}$} \\
\hline & & $1954-55$ & $1955-56$ & & & $1954-55$ & $1955-56$ \\
\hline & & +76 & +5 & aíses Bajos & & $+0,9$ & + \\
\hline & & & & ruguay & & $+12,4$ & 2,8 \\
\hline & & $+18,5$ & +2 & élgica $\ldots \ldots$ & & $+\quad 1,2$ & + \\
\hline del Sur & & $+49,6$ & & Estados Unidos. & & $+0,3$ & + \\
\hline $\begin{array}{lllll} & \ldots & \ldots & \ldots\end{array}$ & $\ldots$ & $-1,1$ & +1 & Canadá $\ldots . . .$. & & $+0,1$ & + \\
\hline enting ... . . . & $\ldots$ & $+7,2$ & +1 & $2025, \ldots \ldots$ & & $-1,3$ & + \\
\hline 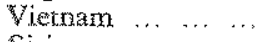 & & $+12,7$ & & & & $+4,0$ & + \\
\hline$a \quad \ldots \quad \ldots \quad \ldots$ & $\ldots$ & $-1,1$ & +1 & Dominicana....... & & $-2,5$ & + \\
\hline$\ldots \ldots$ & $\ldots$ & $-3,8$ & & cente & & $+7,2$ & + \\
\hline & $\ldots$ & $-0,1$ & +1 & Lia. & & $+1,8$ & + \\
\hline esia $\ldots \ldots \ldots$ & $\ldots$ & $+32,4$ & & & & 0,3 & + \\
\hline adia $\ldots . .$. & $\ldots$ & $-2,9$ & +1 & mburgo & & $-0,1$ & + \\
\hline$\ldots \ldots \ldots$ & $\ldots$ & $+5,3$ & & odia $\ldots$ & & $+19,2$ & $+\frac{i}{t}$ \\
\hline $\operatorname{arania} \quad \ldots \quad \ldots$ & $\ldots$ & $+5,6$ & + & Rica ... ... & & $+\quad 1,2$ & + \\
\hline nbia $\ldots \ldots \ldots$ & $\ldots$ & $+0,4$ & + & ania (Rep. Fed.). & & & + \\
\hline $\begin{array}{lll}\text { Hia } & \ldots & \ldots\end{array}$ & $\ldots$ & $+2,9$ & + & glesa....... & & $+2,5$ & + \\
\hline$a$ & $\ldots$ & $+6,0$ & $\frac{1}{3}$ & via... & & $+12,9$ & + \\
\hline ... $\ldots$ & $\ldots$ & $+16,5$ & + & & & & + \\
\hline . ... $\ldots$ & $\ldots$ & $+11,7$ & + & ed. de) & & 1,6 & 4 \\
\hline$\ldots \ldots$ & $\ldots$ & $+8,8$ & + & $0 \ldots \ldots$ & & $-1,9$ & + \\
\hline Kong $\ldots \quad \ldots$ & $\ldots$ & $-4,1$ & + & aka ....... & & 3,1 & + \\
\hline & $\ldots$ & $-3,5$ & + & $a \quad \ldots \quad .$. & & 2,2 & + \\
\hline & $\ldots$ & $+13,0$ & + & & & $+\quad 6,9$ & + \\
\hline $\begin{array}{lll}\ldots & \ldots & \ldots\end{array}$ & $\ldots$ & $+4,5$ & + & & & $-0,1$ & + \\
\hline & $\ldots$ & $+2,4$ & & as.. & & $+5,3$ & + \\
\hline . & $\ldots$ & $+4,3$ & + & Sudafrica & & & + \\
\hline (isla) $\ldots \ldots$ & $\ldots$ & 0,0 & + & rica Oced Francesa. & & 1,8 & + \\
\hline $\begin{array}{lll}\ldots & \ldots & \ldots\end{array}$ & $\ldots$ & $+6,6$ & + & $\begin{array}{lllllll}n & \ldots & \ldots & \ldots & \ldots & \ldots\end{array}$ & & $-1,0$ & + \\
\hline & $\ldots$ & $+7,9$ & & 皮 & & 1,5 & + \\
\hline Zelanda ... & $\cdots$ & $+2,3$ & + & .. & & & + \\
\hline 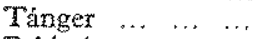 & $\ldots$ & $-1,0$ & + & lad. & & $+4,7$ & + \\
\hline $\begin{array}{llll}\cdots & \ldots & \ldots\end{array}$ & $\cdots$ & $-3,6$ & +4 & & & $+11,5$ & + \\
\hline$\ldots \ldots$ & $\ldots$ & $+2,5$ & & ncesa. & & & \\
\hline & $\ldots$ & $-1,0$ & & sta) $\ldots \ldots$ & & $-3,2$ & + \\
\hline $\begin{array}{rrrr}\mathrm{rca} & \ldots & \ldots\end{array}$ & $\ldots$ & $+7,7$ & + & $\ldots \ldots$ & & $-0,6$ & \\
\hline $\begin{array}{lll}\ldots & \ldots & \ldots\end{array}$ & $\ldots$ & + & & $\cdots \cdots$ & & $+7,0$ & + \\
\hline & $\ldots$ & +3 & + & & & & \\
\hline & $\ldots$ & +5 & & $\ldots \quad \ldots$ & & $+17,8$ & +0 \\
\hline a del Norte & $\cdots$ & $+3,8$ & $+3,1$ & & & $+0,1$ & -0 \\
\hline $\begin{array}{llll}a & \ldots & \ldots & \ldots\end{array}$ & $\ldots$ & $+3,3$ & $+3,1$ & & & & \\
\hline & & $+3,2$ & & as británica & & & -1 \\
\hline $\begin{array}{llll}\cdots & \ldots & \ldots & \ldots\end{array}$ & & $+0,9$ & +3 & & & & \\
\hline & & $+3,1$ & & & & & -2 \\
\hline & & +5 & + & & & & \\
\hline & & $+4,7$ & $+3,0$ & Guatemala & & $+8,6$ & $-8,0$ \\
\hline
\end{tabular}




\section{CRONICAS \\ I. - Magisterio Eclesiástico}

\section{SANTA SEDE}

Ya en impresión este número, nos llega el resumen telegráfico del Discurso de Su Santidad en la Sala del Consistorio, el dia 7 de mazzo, a unos seiscientos miembros de la. Unión Cristiana de Dirigentes de Empresa de Italia, reunidos con motivo del X Aniversario de su fundación.

Es la UCID italiana una de las más florecientes asociaciones de patronos cristianos, semejante a nuestra Acción Social Patronal, y como ésta, integrada en la Union Internationale des Associations Patronales Catholiques (UNIAPAC).

Desde el punto de vista social han sido memorables ya otros discursos del Papa a la UCID italiana, como el del 31 de enero de 1952 a propósito de la cogestión obrera y del régimen de las empresas. Por eso se esperaba con especial interés este nuevo Discurso del Pontifice, y por eso también nos hacemos eco del mismo, aun sin haber podido leer el texto integro, por no dejar su mención para la Crónica del próximo trimestre.

Dos ideas centrales parece que han sido las dominantes en este Discurso: la primera relativa a los graves problemas de la automatización y las nuevas técnicas; la segunda a los peligros de la centralización estatal y de la inhibición social e individual en el cumplimiento de los fines de la convivencia humana.

Cree el Pontifice que la automatización, como el industrialismo procedente, puede resolverse en definitiva en auténtico progreso y elevación de los hombres; pero con tal que se superen previsoramente los trastornos que sin duda puede crear. «Es necesario adoptar desde ahora - dice- las oportunas medidas de prevención para que el dinamismo de la técnica no degenere en una calamidad pública. En todo caso es preciso que los empresarios acepten el principio de que la técnica está al servicio de la economía, y no al contrario,

Respecto de la otra idea relativa a la justa distribución entre la actividad estatal y social de los ciudadanos, es oportuno copiar los siguientes párrafos en que hemos subrayado por nuestra cuenta algunos conceptos más esenciales. 
4En cambio, todo ciudadano debe ser consciente de que el Estado, cuya intervención se pide concretamerte y en uiltimo término, es sierapre la colecuvidad de los mismos ciudadanos y que, por lo tanto, nadie puede prescindir de las obligaciom nes y cargas a las que él mismo no está dispuesto a contribuir, atunque sólo sea con la conciencia de la responsabilidad ex el uso y los derechos que le concede la ley. En realidad, las cuestiones de la economía y de las reformas sociales no depen den sino muy externamente del buen funcionamiento de ésta o aquella institucion, suponiendo que no estén en oposición con el derecho natural. Pero tienen un nexo necesario e intimo con la cualidad personal del hombre, con su fuerza thoral y la buena voluntad que asume responsabilidades, y entiende y trata con suficiente cultura y ptreza todo lo que emprende o a lo que esta obligado...

«El deciros todas estas cosas - -añadió-, queridos empresarios y dirigentes, es porque estamos persuadidos de que precisamente nuestra posición en la vida os pone a diario delante de los ojos como lo que tiene mayor importancia es el hombre mismo. Ninguna ordenación kacendistica, ningún instiruto profesional o legislativo, como tampoco ninguna vasta organización con funcionarios y asambleas, puede crear o sustivitr ef valor personal del hombre...

Rendido este tributo a la actualidad, no podemos dejar de hacer mernción, aunque con el retraso que el régimen de nuestra Revista nos impone, del más importante Documento pontificio del trimestre. Nos referimos al Radiomensaje de Navidad dirigido a los fieles y pueblos de todo el roundo a través de la Radio Vaticana, el día 23 de diciembre.

Se trata realmente de un documento profundísimo, exponente de las esperanzas, angustias y peligros de la humanidad en este periodo histórico.

Gira todo él en torno a la dramática contradicción en que se debate el hombre moderno, y que el Papa describe de esta manera: «De una parte la esperanza confiada del hombre moderno, artifice y testigo de la «segunda revolución técnica», de poder crear un mundo abundoso de bienes y de obras, libre de la pobreza y de la incertidumbre. De otra parte la amarga realidad de largos años de luto $y$ de ruinas, con el consiguiente temor, agravado en estos álimos meses, de no poder echar el fundamento, tan siquiera, de un modesto principio de armonia duradera y de paz.

El Papa agrupa después su luminosa doctrina en tres capitulos: 1) Dig nidad y limites de la naturaleza humana. 2) El acto libre y la realidad humana. 3) La verdad absoluta, luz y vida del hombre.

Respecto del primer punto, frente al optimismo de una concepción técnica del hombre en consonancia con la concepción técnica de todo el universo, que espera resolver los problemas humanos como los demás problemas del maquinismo, pero que lleva implicito un concepto degradante de la naturaleza humana al despojarla de su específica dignidad, establece el Papa la doctrina tradicional y cristiana respecto del hombre, con toda la grandeza que le da su imagen de Dios y la obra redentora de Cristo, y toda la debilidad y miseria del pecado. Ya al final de este primer capítulo, de tanto contenido filosófico y teológico, leemos esta oportuna aplicación: "Pero la reforma de las instituciones no es tan urgente como la de las costumbres. La cual a su vez no puede ser llevada a cabo sino sobre la base de la verdadera realidad del hombre, la que se aprende con religiosa. humildad ante la cuna de Belén». 
En el segundo capitulo, denuncia el Papa el otro error de ese peramimiento falsamente llamado realista que está en la base de la dramática contradicción del hombre moderno, y que consiste en la pretensión de crear una sociedad completamente nueva usin preocuparse de la realidad histórica del hombre, así como dell acto libre que la determina, ni de la religión que nutre y sanciona esta libertad».

El Papa vindica a continuación estos tres valores, de la historia, de la libertad y de la religión en la constitución y progreso de la sociedad humana. De este capitulo entresacamos los siguientes párrafos.

-La religion y la realidad del pasado exaseran que las estrucuras sociales, como a matrimonio y la familia, la comunidad y las profesiones mancomunadas, la unión social dentro de la propiedad personal, son células esenciales que aseguran la libertad del hombre, y con esta, su papel ex la historia. Son intangibles, por tanto, y la sustancia de ellas no puede estar sujeta a arbitratias wevisiones... a Es cicrtamenze landable la soliciwd por mejorar las estructuras sociales existentes y susceptibles de mejoramiento, pero sería un exror que el hombre, sometido al influjo de la técnica y de la organización moderna, fuese arrancado de todas sus tradiciones... «Así que el respeto hacia todo lo que la historia ha producido es señal de la genuina voluntad de introducir reformas y garantía de su resultado feliz,

En el tercer capítulo vindica el Papa el fundamento inconmovible de la verdad absoluta, luz y vida del hombre, como base de toda moral, de toda sociología, y, por ende, de la solución de las contradicciones actuales. Medítese la oportunidad e importancia del siguiente párrafo:

2. Con profundo pesar debenos lamentar a este propósito el que algunos catolicos, eclesiásticos y láicos presten su apoyo a la táctica del confusionismo para obtene" un efecto que ellos mismos no desean. ¿Cómo es posible aún no ver que éste es el fin de todo aquel insincero agitarse que se oculto bajo el nombre de "conversacio nes" y de "encuentros"? ¿Qué objeto tiene, por lo demás, el ponerse a razonar sin tener un lenguaje comin, o cómo es posible encontratse si los caminos son divergentes y sí, por lo que hace a una de las partes, se rechazan obstinadamente y se niegan los valores absolutos comunes, haciendo asi inactuable cualquier "coexistencia en la verdad"? Es hora de que, por respeto al hombre cristrano, se desista de prestarse a dichas tácticas, porque, como amonesta el apbstol, es inconciliable el guerer sentarse a la mesa de Dios y a la de sus enernigos (cef. I Cor., 10, 21),

Refiriéndose después a la causa de la paz, y especialmente a la perturbación ocasionada por el caso de Hungría, pronuncia el Papa las siguientes palabras: «Nos, estamos persuadidos de que también hoy, frente a un enemigo resuelto a imponer de un modo o de otro a todos los pueblos una particular e intolerable forma de vida, sólo una unánime y fuerte actitud de todos los amantes de la verdad y del bien puede salvar la paz, y la salvará.s

Muy notable es, en fin, pero ya divulgada por la prensa, la úlitima parte del Discurso en que habla el Papa de la solidaridad de Buropa como uno de los medios para la paz del nundo, y de la necesidad de afianzar la autoridad y prestigio de las Naciones Unidas. 
Otro gran discurso de Su Santidad ha sido el del 24 de febrero, a una reunión de Médicos de todo el mando, sobre el empleo de anestésicos. Por teferirse menos a la especialidad de esta Revista el importante docimento pontificio, transcrito literalmente por la prensa catolica, nos limitaremos a copiar los siguientes párafos, relativos tal vez al punto más difícil de los propuestos a la consulta del Papa.

《 \{Habrá que renunciar al narcótico si su acción acortase la duración de la vida? Desde luego, toda forma de eutanasia directa, o sea, de administrací́n de rarcóticos con el fin de protocar o acelerar la muerte, es ilicita, porque entonces se pretende disponer directamente de la vida... (pero) en la hipótesis a que os referís se trata unicamerte de evitar al paciente dolores insoportables; por ejemplo en casos de cancer inoperable o de enfermedad incurable

"Si entre la anarcosis y el acontamiento de wida no existe nexo alguno causa! directo, puesto por la voluntad de los interesados o por la raturaleza de las cosas (como serfa el caso, si la supresión del dolor no se pudiese obtener sino mediante el acortamiento de la vía), y si, por el contrario, la administración de nuxcóticos procujese por si misma dos efectos distintos, por hna parte el alivio de los dolores y por otra la abreviación de la vida, entonces es lícita; habría aún que ver si entre esos dos efectos existe una proporción razonabley y si las ventajes del uno compensan los inconvenientes del otro.»

No podemos detenernos en el extracto de otros documentos pontificios de este trimestre, cuya enumeración insertamos por orden cronológico de su aparición en \&L'Osservatore Romanow.

3-4 dic.: Radiomensaje del día 2 para 1a clausura del II Congreso Eucorístico Nacional de Filipinas, celebrado en Manila bajo la presidencia del Card. Spellman, legado pontificio. En inglés, pero tiene una interesante segunda parte en castellano.

5 dic.: Radiomensaje, en castellano, el dia 2 de diciembre, en la clausura de las solemnidades de la Argentina en honor de Ntra. Sra. de los Emigrantes.

10-11 dic; Discurso, el 8 de diciembre, en francés, al Consejo de la Federación Internacional de Hombres Católicos.

13 dic.: Breve Discurso el martes 11, a 1a «Comisión Nacional Italiana de la Liga por la Lucha contra los Ruidos》.

14 dic.; Mensaje, en francés, a la III Asamblea General de la Federación Internacional de la juventud Católica, reunida esos dias en Roma.

17-18 dic.: Radiomensaje, el domingo 16. en costellano, en la clausura del
II Congreso Eucarístico Bolivariano, celebrado en Caracas.

24-25 dic:: Radiomensaje de Naxidad dirigido a todo el mundo, el domingo, 23 , a las 11 de la mañana.

5 enero: Carta, en francés, de Mons. Dell'Acqua con ocasión de las Jornadas Internacionales de Estudio sobre el Cine, en La Habana, del 4 al 11 de enero. 7-8 enero: Radiomensaie, el domingo 6 , con ocasión de la fornada de la Madre $y$ del Niño.

19 enero; Discurso, en castellano, a un grupo de estudiantes de Arquitectura de la Universidad Iberoamericana de Méjico.

20 enero: Breve salutación, en inglés, el sábado 19, al Ministro de Asuntos Exteriores de Gran Bretaña.

25-26 febrero: Extenso Discurso de Su Santidad, en francés, el día 24, a una Reunión de Médicos, especialmente anestesiólogos, resolviendo tres casos morâles propuestos sobre analgesia. 


\section{EPISCOPADO ESPANOL}

Con fecha 4 de diciembre dirigio Su Sancidad una expresiva carta latina de felicitación a nuestro Cardenal Primado, Dr, ta y Deniel, Arzobispo de Toledo, con ocasión del octogésino aniversario, acaecio el dia 19 del rnismo mes.

Toda la prensa se ha ocupado extensamente de esta efenéride, con mom tivo de la cual han sido numerosos los actos de homenaje y de adhesión tributados a la más alta digridad de la Iglesia española.

Al recordar aquí tan merecidos homenajes, que se han mantenido, con todo, en un ambiente de modestia e intimidad impuesto por el mismo Sr. Cardenal, no queremos dejar de hacer mención, de acuerdo con el carécter de nuestra Revista, de la tntensa significación social del apostolado de Cardenal Pla y Deniel a lo largo de sus prolorgados cudados pastorales. Quedemos recordar principamente que sus campañas sociales y. su vocación por este género de apostolado surgieron ya antes de su promoción al episcopado, trabajando fructuosamente en Barcelona con la aguada de aquel no table apóstol de la acción social que fué el $P$. Gabriel Palau, $S$. I. En cierto modo, podríamos considerar la misma Institución de FombNo Socral como un fruto de aquellas actividades que tuvieron su comienzo en la Compañáa de Jesús con el P. Antonio Vicent, y de las que constituye una etapa, quizá demasiado olvidada, la relevante labor del P. Palau.

Durante la última reunión de los Rvảmos. Metropolitanos como Junta suprema de la Acción Católica española, acordó dar a ésta por consigna para el próximo bienio "Los deberes sociales de los católicos». A tan importante consigna dedicamos un comentario en nuestro primer Editorial.

Es de destacar la creación en Bilbao del Instituto Católico Diocesano, erigido por el Excmo. Sr. Obispo Dr. Gúrpide Beope, que ha nomorado Vicerrector del mismo al Provisor de la Diócesis, D. José Arbeo. Entre Las comisiones que constituyen el nuevo Centro, hay una relativa a las ciencias económicas y sociales.

La Obra de enseñanza profesional de la Iglesia cuenta con un nuevo importante Centro, por la creación en Cazalla de la Sierra (Sevilla) de la Escuela Profesinoal Diocesana de Ntra. Sra. del Monte.

La Comisión de Semanas Sociales, presidida por el Excmo. Sr. Obispo de Córdoba, ha acordado celebrar la próxima en Pamplona, en la semana del 10 al 16 de junio, y versará sobre el tema: «Por una comunidad internacional». Mucho desearíamos que este año alcanzaran las Semanas Sociales de España el esplendor que les corresponde, mediante la asistencia a la misma de las más relevantes personalidades españolas en la Acción Social Católica.

Muy oportuna y eficaz es la Pastoral del Sr. Patriarca Obispo de Madrid, sobre el influjo que pueden tener los Ejercicios Espirituales de San Ignacio, 
dentro de su propio espítitu y sin desviación de su autenticidad, para formar la conciencia social de los cristianos, en cumplimiento de la consigna arriba mencionada de los Metropolitanos españoles.

Finalmente, aunque no sea con la extensión que merece, queremos ocuparnos de la Pastoral del Sr. Arzobispo de Zaragoza, de fecha 29 de enero, sobre la "Teologia de la Técnica».

Conocida es la importante serie de Pastorales que sobre las relaciones de la Teología con distintos aspectos de los problemas económico-sociales ha escrito Mons. Morcillo. Esta última Pastoral prosigue en la misma línea, y puede considerarse a su vez como una glosa de los documentos pontificios en que tan de propósito y con tanta reiteración se vienen desarrollando los problemas que suscita la revolución técnica de nuestro tiempo. Debemos limitarnos a copiar algunos párrafos del precioso documento, que bastarán para incitar a la lectura completa del mismo a los que tengan necesidad de una mayor información.

«Si la técnica lograra, como ya se puede predecir, elevar tono de vida material de las gentes humildes que trabajan, ya merecería en justicia nuestra gratitud y respeto... La justicia social recibirá de la técnica, y está reciendo ya de ella, su soporte definitivo. Cuando los bienes son insuficientes, no es fácil convencer al poseedor de la obligación de distribuirlos. Un régimen abundancial de bienes como el gue puede llegar a instaurar la técrica, en el que remita el temor a la escasez, es un buen ariete contra el egósmo y contra la insolidaridad social... Lia antinomia de la técrica se plantea sin embargo entre seguridad e inseguridad. Mam yor seguridad frente al mundo físico y mayor inseguridad frente a los hombres, porque son más mortiferas las atmas que pueden manejar...

《Todo descubrimiento técnico produce un eco sociológico tan luego como desciende al campo de las aplicaciones... Es licito conjeturar, por lo que ya estamos viendo, que la era técnica nos llevará de la mano insensiblemente a un capitalismo de Estado levemente atenuado por un supercapitalismo privado, del que serán muy pocos los partícipes...; y será un paso más, temible paso, que dará el Estado moderno si la iniciativa privada no lo remedia a tiempo, hacia la absorción del individuo y de los derechos que le son inseparables...

«Orra hipótesis más rosada puede construirse... La creación de grandes consorcios en los que el acceso resultara fácil para todas las clases sociales, y en los que al capital de unos pocos se sumara el ałorro de obreros, empleados y pequeños propietarios...

La actitud cristinna ante la técnica ha sido reiteradamente expuesta por el Sumo Pontifice, y Mons. Morcillo resume sus enseñanzas. Habriamos de añadir, como ullimo testimonio, el que hemos comentado brevemente al principio de esta Crónica.

En el séptimo y último párafo de su Pastoral hace muy concretas aplicaciones de las ideas generales de la situación de España y de Aragón, el Sr. Arzobispo de Zaragoza. Cerremos sus reflexiones con las que suscita el siguiente párrafo: «Sobre cualquier lugar donde apunte la próxima aparición de una industria y del conflicto sociológico consiguiente, debemos hacernos presentes con una acción intensa que disponga a las almas a recibir, 
sin quebranto y sin hundimiento, la nueva situación. Cerrar a los ojos a desentenderse de los hechos es sumirse y sumir a los dexás en el vacio y vivir alejados de la tierra que pisamos y del Evangelio en el cual creernos.»

M. M. M.

\section{II. - Crónica Social de España}

Aun cuando, como de ordinario, hay algunas notas destacadas que nos van a ocupar preferentemente en estas páginas de crónica, queremos senalar al paso, como ejemplo, ciertas manifestaciones de una preocupación social que se generaliza, gracias a Dios.

Como final del año ignaciano se celebró en Barcelona un Congreso del 12 al 16 de diciembre úlumo. Una de las secciones práctico-pastoral del Congreso se enfrentó con el problema de la "Formación social de los Postgram duados». Aparte de las ponencias a cargo de ilustres personalidades, el diá logo con los oyentes dió interés al tema.

Pocos dias después inauguraba su XXV Asamblea la FAE, buscando con sentido educacional al dia "La formación social del adolescente». El tema fué desglosado en una serie de conferencias, analizándolo desde todos los puntos de vista. Visión certera de los organizadores, el señalar un tema para meter preocupación en los educadores por esta formación, sin duda un tanto olvidada hasta el presente.

En Bilbao el Excmo. Sr. Obispo ha fundado un Instituto Católico Diocesano. Comenzó a funcionar a principio de año, con una Semana de Estudios para sacerdotes con el tema general «La adaptación de la Iglesia a los tiempos actuales, según el pensamiento de Pio XII», interviniendo varios ponentes con estudios como "La Empresa según Pío XII», «La excomunión contra el comunismo», etc. Una de las comisiones será de Ciencias Económicas y Sociales.

Más trascendental que todo lo anterior es la decisión de los Rvdmos. Metropolitanos españoles de señalar como consigna para el bienio $1957-58$ « Deberes sociales de los católicos en la hora presente». El fruto se habrá de recoger a lo largo de los años, con conferencias, cursillos, círculos de estum dio, publicación en revistas, etc. En Madrid se ha iniciado la campaña con una Pastoral del Excmo. Sr. Patriarca-Obispo sobre los Ejercicios de San Ignacio, como medio eficaz de despertar la conciencia social de los católicos; y una Jornada Diocesana para la aplicación de los Ejercicios a urgir esa consigna.

Elegimos como tema central de este comentario la mirada al campo español, que han supuesto la conyersación de Prensa del Excmo. Sr. Ministro 
de Agricultura, y el Coloquio sobre crecimiento económico, en el Instituto de Cultura Hispánica, el 15 de febrero último.

En el Coloquio, el Sr. Martín Sánchez combatió el pesimismo de que España, en su aspecto agrícola, es un país sin remedio. No puede ser ni vergel ni desierto; aun cuando hay que trabajar por que tenga más del primero que del segundo.

El Sr. Ministro enjuició agricolamente el año 1956; no malo, menos caaastrófico; y sí con circunstancias especiales.

No podemos olvidarnos en estos momentos, cuando se está operando un fuerte proceso de desarrollo industrial, de que la agricultura no solamente satisface las necesidades del abastecimiento nacional, siro que es la fuente principal de las divisas de que, hoy por hoy, disponemos, y que es, gran parte a su costa, como hay que llevar a cabo la industrialización del país. El ã̃o 1956, por el descenso de producción de artículos exportables - naranjas, limones...-, ha puesto de manifiesto, una vez más, la importancia de la agticultura dentro de la economía nacional. Más de tres millones de litros de vinos españoles se venden en Suecia cada año.

En la misma reunión del Coloquio, el Sr. Camilleri sentaba la afirmación de que, para el desarrollo de la economía española, se precisa disponer de más alimentos y materias de los que la agricultura proporciona, sin olvidar que ha de proporcionar también la mayor parte de nuestros productos de exportación. En consecuencia, de no prestarse la debida atención al desarrollo de la agricultura, se mermarían nuestras exportaciones agrarias, con la obligación de importar alimentos, y lógicamente el desarrollo industrial necesario sufriría una paralización.

Abastecimiento nacional.-En 1956 se caracterizó por las siguientes circunstancias: la cosecha de trigo excedió en un 7 por 100 aproximadamente a la de 1955; la de cereales-piensos dos millones de quintales menos, un 9 por 100 inferior a la anterior. Ha habido alarma en el mercado de piensos, al cual ha querido salir al paso el Servicio Nacional del Trigo, llevando ya repartidos 1.700 .000 quintales métricos. La cosecha de remolacha supera en un 27 por 100 a la anterior. La de algodón sobrepasó en un 40 por 100; superior fué también la del vino. La del aceite, aún no conocida, se espera supere en 37 por 100 .

Dentro de los cereales de consumo humano hay que destacar los incrementos logrados en la producción de trigo y arroz, desapareciendo las angustias de aquellos años de escasez, con entrega escasa al Servicio Nacional del Trigo, canalizándose gran parte de la producción hacia el mercado negro.

Esto es el anverso; el reverso, la cruz, viene representado por las heladas que tanto afectan las plantaciones de frutos de exportación: naranjos, limoneros, almendros, avellanos y algarrobos. Es importante analizar las variaciones en las producciones principales, en relación con la media del período precedente: 


\begin{tabular}{|c|c|c|c|c|c|}
\hline \multirow[b]{2}{*}{ PRODUCTOS } & \multicolumn{4}{|c|}{ MULES DE QUINTAELS } & \multirow{2}{*}{$\begin{array}{l}\text { Porcentaje } \\
\text { del anduemo } \\
\text { y de la dis- } \\
\text { mainución }\end{array}$} \\
\hline & $\begin{array}{c}\text { Media } \\
1945-50\end{array}$ & $\begin{array}{l}\text { Media } \\
1951-56\end{array}$ & $\begin{array}{c}\text { Au- } \\
\text { mento }\end{array}$ & $\begin{array}{l}\text { Dismaim } \\
\text { nucion }\end{array}$ & \\
\hline
\end{tabular}

Alimentación:

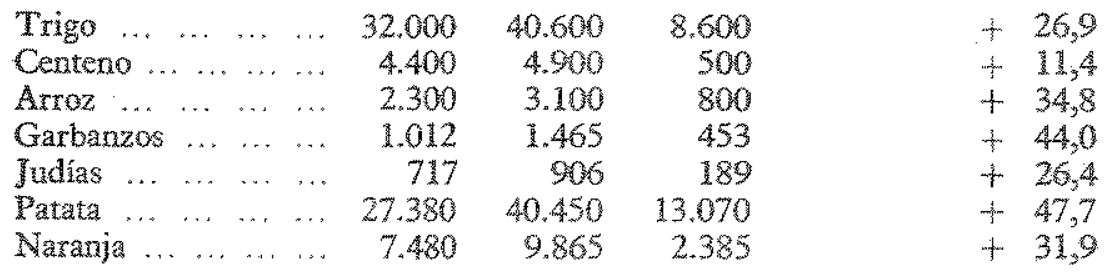

Industriales:

Remolacha azucarera. $\quad 14.300$

Tabaco $\ldots \begin{array}{lllll}\text { Ta } & \ldots & \ldots & 139\end{array}$

Algodón $\ldots \ldots \ldots, \ldots, \ldots$

$\begin{array}{rrr}26.300 & 12.000 & +83,9 \\ 313 & 174 & +126,1 \\ 757 & 627 & +482,3 \\ 66 & 44 & +300,0 \\ 88 & 30 & +51,7\end{array}$

Cáñamo

Piensos y forraies:

\begin{tabular}{|c|c|c|c|c|c|c|}
\hline Cebada ... ... & 17.650 & 18.800 & 1.150 & & + & 6,5 \\
\hline Avena $\ldots, \ldots, \ldots$ & 5.010 & 5.030 & 20 & & + & 0,4 \\
\hline Maiz . & 4.730 & 6.750 & 2.020 & & + & 42,7 \\
\hline Habas $\ldots$... ... & 660 & 1.030 & 370 & & + & 56,1 \\
\hline Algarrobas ... ... ... & 800 & 1.014 & 214 & & + & 26,8 \\
\hline Garrofa $\ldots \ldots \ldots \ldots$ & 4.400 & 3.400 & & -1.000 & - & 22,7 \\
\hline Alfalfa vedre ... & 27.600 & 32.900 & 5.300 & & + & 19,2 \\
\hline Trébol $\ldots \ldots \ldots$ & 2.380 & 4.580 & 2.200 & & + & 92,4 \\
\hline Praderas arificiales. & 9.300 & 10,850 & 1.550 & & + & 16,6 \\
\hline Nabo forraie $\ldots \ldots$ & 17.100 & 24.200 & 7.100 & & + & 41,5 \\
\hline
\end{tabular}

Los porcentajes de aumento más significativo corresponden a las plantas industriales. En concreto las de algodón y lino han sido cinco y tres veces superiores a las del período anterior. El consumo nacional de algodón fué de 400.000 balas al año; las recogidas en nuestro suelo 210.000 . Es de interés, por lo mismo, la ampliacion del área e intensificación del cultivo.

La remolacha azucarera, después de varios años de muy escasa producción de azúcar, alcanzó en la campaña de 1952-53 la cirra récord de 513.000 
toneladas; lo que produjo una perturbación saturadora del marcado. LI Ministerio de Agricultura adopto las medidas para establecer equilibrio entre producción y consumo, reduciendo el precio de la remdacha y limitando st cultivo a las zonas más aptas. El consumo por habitante ha do en aumento, lo que aconseja de nuevo fomentar su cultivo. El consumo del año actual se calcula estará próximo a las 400.000 toneladas, es decir, unas 100.000 toneladas más que hace tan sólo tres o cuatro años.

Circunstancia importante al enjuciar este problema es el gran númeto de pequeños propietarios del campo con el doble carácter de empresario y obrero agricola. Segun datos, existe un total de 1.655 .000 productores de trigo, de los cuales sólo 110.000 son cultiyadores de más de seis hectáreas, constituyendo el milión y medio restante la gran base de la pirámide de la agricultura española. La situactón de estos modestos productores es análoga a la del obrero agrícola, con anterionidad a la subida de salarios, ya que las más de las veces no son otra cosa que población trabajadora que cobra su jornal en trigo, y de cuyo precio depende el gue lleguen o no a alcanzar los salarios mínimos establecidos por las Reglamentaciones de trabajo.

II Sr. Marún. Sánchez, al senalar la dificultad de los camoblos de estructura en la producción agrícola, dice que en España hay 1.400 .000 empresarios trigueros, es decir, agricultores independientes que cultivan trigo. De ellos, un millón cultivan menos de dos hectáreas, y sólo 500 labran más de 150 hectáreas. Lo mismo ocurre en las demás producciones del secano, como lo prueban las estadísticas de Hacienda, que de 2.700.000 contribuyentes por riqueza rústica, dos millones están ezentos de contribución por reunir menos de 50 pesetas de líquido imponible.

Crédito agricola.-Merced sobre todo a la ley de 30 de marzo de 1954 , el volumen de operaciones concertadas entre el Servicio Nacional de Crédito Agrícola y los agricultores ha adquirido una importancia grande. El número anual de los beneficiarios, que durante los años 1951-54 oscilaba entre 35.000 y 50.000 , se ha duplicado en los dos últimos at̃os; el importe de los préstamos, que variaba entre 100 y 500 millones, se ha elevado en 1956 a 1.980 . Han sido concedidas a las Secciones de Crédito y a las Cooperativas. La distribución por provincias es como sigue:

\begin{tabular}{|c|c|c|c|}
\hline PROVINCIAS & Secciones & Socios & Pesetas \\
\hline 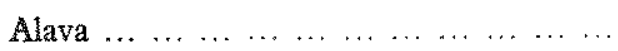 & 1 & 32 & 450.000 \\
\hline 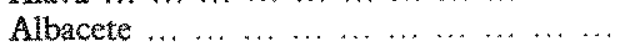 & 14 & 1.947 & 16.575 .000 \\
\hline $\begin{array}{llllllllll}\text { Alicante } & \ldots & \ldots & \ldots & \ldots & \ldots & \ldots & \ldots & \ldots & \ldots\end{array}$ & 4 & 384 & 8.080 .000 \\
\hline 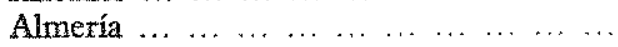 & 9 & 334 & 1.675 .000 \\
\hline 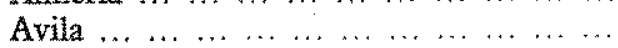 & 11 & 860 & 3.260 .000 \\
\hline 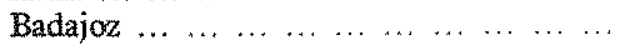 & 14 & 602 & 3.955 .000 \\
\hline Barcelona $\ldots \ldots \ldots \ldots \ldots \ldots \ldots \ldots \ldots$ & 4 & 172 & 1.445 .000 \\
\hline
\end{tabular}




\begin{tabular}{|c|c|c|c|}
\hline PROVINCLAS & Secciones & Socios & Peseras \\
\hline Burgos $\ldots \ldots \ldots \ldots \ldots \ldots \ldots \ldots \ldots$ & 9 & 132 & 960.000 \\
\hline 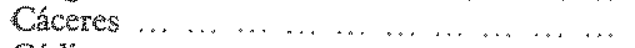 & 4 & 317 & 1.100 .000 \\
\hline 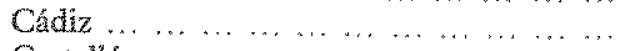 & 4 & 415 & 3.200 .000 \\
\hline 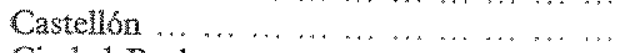 & 17 & 1.123 & 7.480 .000 \\
\hline Ciudad Real $\ldots \ldots \ldots \ldots$ & 9 & 2.230 & 10.230 .000 \\
\hline 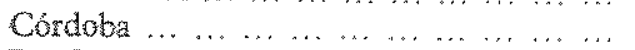 & 7 & 516 & 8.640 .000 \\
\hline La Coruña $\ldots \begin{array}{llllllll} & \ldots & \ldots & \ldots & \ldots & \ldots & \ldots & \ldots\end{array}$ & 5 & 285 & 1.090 .000 \\
\hline $\begin{array}{llllllllll}\text { Cuenca } & \ldots & \ldots & \ldots & \ldots & \ldots & \ldots & \ldots & \ldots & \ldots\end{array}$ & 18 & 1.159 & 8.675 .000 \\
\hline 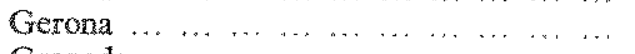 & 4 & 82 & 920.000 \\
\hline 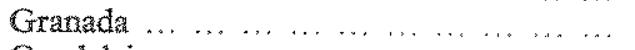 & 7 & 396 & 3.400 .000 \\
\hline 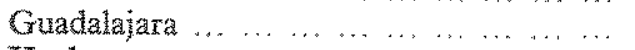 & 6 & 92 & 1.195 .000 \\
\hline $\begin{array}{lllllllllll}\text { Huelva } & \ldots & \ldots & \ldots & \ldots & \ldots & \ldots & \ldots & \ldots & \ldots & \ldots\end{array}$ & 10 & 1.179 & $13.450,000$ \\
\hline $\begin{array}{lllllllllll}\text { Muesca } & \ldots & \ldots & \ldots & \ldots & \ldots & \ldots & \ldots & \ldots & \ldots & \ldots\end{array}$ & 5 & 129 & 660.000 \\
\hline 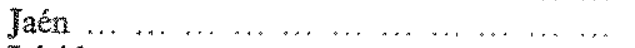 & 10 & 2.004 & 20.400 .000 \\
\hline $\begin{array}{lllllllllll}\text { Lérida } & \ldots & \ldots & \ldots & \ldots & \ldots & \ldots & \ldots & \ldots & \ldots\end{array}$ & 21 & 1.465 & 12.500 .000 \\
\hline $\begin{array}{lllllllll}\text { Logroño } & \ldots & \ldots & \ldots & \ldots & \ldots & \ldots & \ldots & \ldots\end{array} \ldots$ & 1 & 79 & 120.600 \\
\hline $\begin{array}{llllllllll}\text { Lugo } & \ldots & \ldots & \ldots & \ldots & \ldots & \ldots & \ldots & \ldots & \ldots\end{array}$ & 4 & 498 & 2.305 .000 \\
\hline 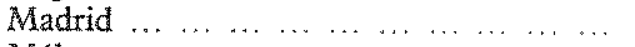 & 8 & 187 & 2.415 .000 \\
\hline $\begin{array}{ccccccccccc}\text { Málaga } & \ldots & \ldots & \ldots & \ldots & \ldots & \ldots & \ldots & \ldots & \ldots & \ldots\end{array}$ & 10 & 1.162 & 8.850 .000 \\
\hline $\begin{array}{cccccccccc}\text { Murcia } & \ldots & \ldots & \ldots & \ldots & \ldots & \ldots & \ldots & \ldots & \ldots\end{array}$ & 8 & 937 & 9.400 .000 \\
\hline 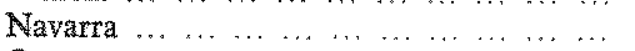 & 4 & 77 & 920.000 \\
\hline 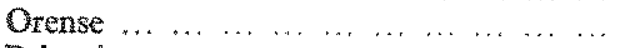 & 3 & 326 & 1.400 .000 \\
\hline 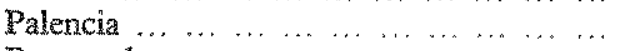 & 7 & 201 & 2.720 .000 \\
\hline 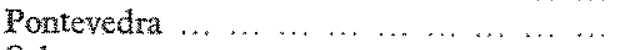 & 10 & 313 & 1.820 .000 \\
\hline $\begin{array}{llllllllll}\text { Salamanca } & \ldots & \ldots & \ldots & \ldots & \ldots & \ldots & \ldots & \ldots & \ldots\end{array}$ & 3 & 45 & 650.000 \\
\hline $\begin{array}{llllllllll}\text { Segovia } & \ldots & \ldots & \ldots & \ldots & \ldots & \ldots & \ldots & \ldots & \ldots\end{array}$ & 4 & 53 & 430.000 \\
\hline 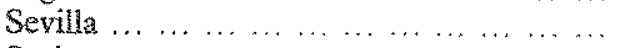 & 3 & 247 & 4.030 .000 \\
\hline $\begin{array}{llllllllll}\text { Soria } & \ldots & \ldots & \ldots & \ldots & \ldots & \ldots & \ldots & \ldots & \ldots\end{array}$ & 17 & 329 & 2.582 .000 \\
\hline $\begin{array}{cccccccccc}\text { Tarragona } & \ldots & \ldots & \ldots & \ldots & \ldots & \ldots & \ldots & \ldots & \ldots\end{array}$ & 57 & 3.840 & 32.170 .000 \\
\hline 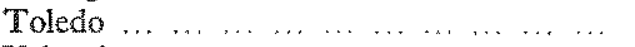 & 19 & 1.322 & 13.075 .000 \\
\hline $\begin{array}{rlllllllll}\text { Valencia } & \ldots & \ldots & \ldots & \ldots & \ldots & \ldots & \ldots & \ldots & \ldots\end{array}$ & 30 & 4.203 & 36.820 .000 \\
\hline 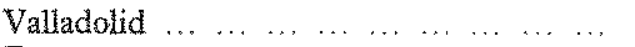 & 4 & 122 & 695.000 \\
\hline 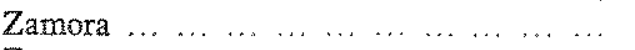 & 13 & 516 & $4.550,000$ \\
\hline Zaragoza $\ldots \ldots \ldots \ldots \ldots \ldots$ & 17 & 1.76 & 10.345 .000 \\
\hline TOTAL $\ldots \ldots \ldots c c c c c c$ & & & \\
\hline
\end{tabular}

Concentración parceloria.-Iniciada en 1953 ha tenido una favorable acom gida por los agricultores, a pesar de las dificultades y comentarios encontrados. Hubo proceso de recelo, desconfianza y espera. Pero el cuadro siguiente expresa el deseo de 150.000 agricultores: 


\begin{tabular}{|c|c|c|c|}
\hline $\mathrm{ANOS}$ & $\begin{array}{l}\text { Numero } \\
\text { de } \\
\text { solicitudes }\end{array}$ & $\begin{array}{l}\text { Numero } \\
\text { de } \\
\text { pueblos }\end{array}$ & $\begin{array}{l}\text { Superficies } \\
\text { (Has.) }\end{array}$ \\
\hline $\begin{array}{lllllllllll}1953 & \ldots & \ldots & \ldots & \ldots & \ldots & \ldots & \ldots & \ldots & \ldots & \ldots \\
1954 & \ldots & \ldots & \ldots & \ldots & \ldots & \ldots & \ldots & \ldots & \ldots & \ldots \\
1955 & \ldots & \ldots & \ldots & \ldots & \ldots & \ldots & \ldots & \ldots & \ldots & \ldots \\
1956 & \ldots & \ldots & \ldots & \ldots & \ldots & \ldots & \ldots & \ldots & \ldots & \ldots\end{array}$ & $\begin{array}{l}35 \\
20 \\
93 \\
96\end{array}$ & $\begin{array}{r}44 \\
24 \\
179 \\
154\end{array}$ & $\begin{array}{r}121.113 \\
43.691 \\
268.440 \\
227.492\end{array}$ \\
\hline TotaL $\ldots \ldots \ldots \ldots \ldots \ldots$ & 224 & 401 & 660.736 \\
\hline
\end{tabular}

Hasta el presente son más de 100 las zonas en las cuales se ha declarado de utilidad pública por el Gobieno la concentración parcelaria, zonas en las cuales han quedado afectadas cerca de $300.000 \mathrm{Ha}$. Se ha terminado la concentración parcelaria etr $54.260 \mathrm{~Hz}$., pertenecientes a 24 pueblos, y se ha tomado posesion de la nueva propiedad en 27.500 Ha. Dato complementario puede ser el de la preocupación por la defensa del suelo contra la erosión; labor realizada en 15,000 Ha. de terrenos con pendientes más o menos acentuadas.

También dió cifras el Sr. Ministro sobre los abonos y fertilizantes distribuidos en el último perído. El consumo crece de año en año, lo que se refleja en parte en las importaciones de fosforitas, que han pasado de 750.000 toneladas mérricas en 1953 a cerca del millón de toneladas en el útrimo año.

El almacenaciento de granos es punto básico para el desarrollo de una política de estabilización del mercado. En la actualidad se hallan en explotación 158 silos y 132 graneros, con una capacidad total próxima a los cinco millones de quintales métricos. Hay en ejecución 59 silos más y 41 gram neros, esperándose con ello llegar a la capacidad de almacenamiento de 7,5 millones de quintales, más los tres millones que puede recogerse en las fábricas de harinas.

El enigma del aceite.-Productora España de aceite no llega a cubrir las necesidades de consumo de los úttimos años; hay importacion. Para remediar temporal o definitivamente este problema, dos soluciones se ofrecen: intensificar la producción de aceite por mejora en el cultivo del olivar y nuevas plantaciones; y el aprovechamiento de semillas oleaginosas de posible cultivo en nuestro pais: algodón, soja, cacahuete. \ ¿cómo somos exportadores de aceite de oliva? La razón es que en las actuales circunstancias no podemos restringir nuestra capacidad exportadora tai limitar la producción de diyisas. Nos son necesarias cuantas podamos producir, y el aceite de oliva español está sobradamente acreditado en los mercados exteriores, en los que goza de excelente cotización, y a ellos debemos seguir concurriendo. 
Por lo tanto, ruestros exportadores de oliva nos permiten importaciones de mayor volumen de otros acestes.

El regado.-Interesa nacimalmente intensficar el regadio. Bn $1956 \mathrm{la}$ supericie dominada por redes del Instrituto Nacional de Colonizacion fó de 42,467 Ha. Al comenzar el 1957 se encuentran en periodo de construcción las obras de redes de acequias de 107.662. Ha. esperándose que al finalizar el año se encuentren terminadas otras $50.000 \mathrm{Ha}$. de transfomación anual de regadio. El Parque de Maquinaria del Instituto ha permitido, entre otras obras, la excavación de 110 pozos, y tealizacion de 57 sondeos en busca del agua.

Tiene gran importancia la pequeña obra de regadio que completa la produccion de secano y mejora la agriculura de una pequeña comarca o zona. Los aunatios concedidos a traves de la ley de Colonizacion de Interés Local han permitido contar en 1956 con $30.946 \mathrm{Ha}$. más de nuevos wegadios, que, sumadas a las 42.467 anteriomente indicadas, hacen wn wota de $73.423 \mathrm{Ha}$, cifra jamás alcanzada en nuestro pass, exponente de la actividad del Instituto Nacional de Colonización.

Como consecuencia, el mumero de familias de cultuadores instaladas en las zonas y incas de colonzación durante el 1956 se elevo a 6948 ; el tom tal hasta la fecha está muy próximo a las 45.000 familias: 1na gran parte son colonos del Instituto. El numero de viviendas construidas en los nuevos pueblos del Instituto se elevaba en 1956 a 3.103 ; para 1957 se prevó 1 ia construcción de 3.717 .

Avicultura--Existen actualmente en España unas 2.000 granjas dedicadas a la incubación de pollitos, donde anuamente se incubar de 5 a 6 mim llones de aves. En el último año se ha presentado la crisis par la escasez de plensos; y en los pueblos, por la peste aviar que aún ao saben comba ir eficazmente.

Cultivo del tabaco.-En 1954 Espana dedicaba a su cultivo unz exteri sión de 22.281 Ha. Figuraban en cabeza: Cáceres, Granada, Valencia, To. ledo y Sevilla. Supuso un importe de 393 millones de pesetas. En 1955 la producción representó un total de $30.835 \mathrm{Tm}$ : picadura, cigarros y ciga rritlos. E1 Ministerio de Agricultura, de acuerdo con las caracteristicas climam tológicas y geológicas, ha diversificado el cultivo en nueve zonas: las dos primeras las constituyen las provincias andaluzas, Este y Oeste; la tercera comprende las regiones de Levante y Cataluña, Husesca y Baleares; la cuarta y séptima comprenden la región extremeza; 1 la quinta y sexta se extiende por todo el Norte de la Península; la octava y novena todo el interior. Las clases son muy variadas: tabaco amarillo, claro, habano y sumatra destinado a cigarros puros.

E. DEZ 


\section{III.-Crónica Internacional}

\section{El apastolado sacerdotal en las empresas}

En España el apostolado sacerdotal con los obreros a través de las mismas empresas está bastante desarrolado y reviste diversas formas: capellanes de empresa; Ejercicios Espirituales en completo retiro para obreros y empleados con la colaboración generosa de las empresas; Ejercicios anuales abiertos en la misma empresa; conferencias cuaresmates anuales en la empresa; conferencias religiosas en la emoresa con motivo de misiones en la localidad o en otras ocasiones; conferencia semanal, quincenal o mentul en la misma empresa; clases de religion dadas por un sacerdote en la escuela de aprendices de la empresa.

Por lo que toca al extranjero, puede ser interesante adveritir en este respecto las siguientes experiencias:

\section{ITALIA}

\section{LA ONARMO}

La Obra Nacional de Asistencia Religiosa y Moral al Obrero, en Itaita nació durante la guerra en Génova, primer pueto y gran ciudad industrial de Italia.

El cardenal Boetro y hoy el cardenal Siri, que le sucedió en el arzobispado de Génova, han definido esta experiencia. La organización nacional está bien establecida con servicios precisos. Mons. Torrazza en Génova la dirige. Pero la experiencia se ha extendido a otras ciudades italianas.

La ONARMO agrupa en Génova a 35 consiliarios del trabajo alredem dor de los cuales gira toda la experiencia. Estos consiliarios o capellanes del trabajo, a veces son párrocos. En todo caso están adheridos a una parroquia de la ciudad, donde ejercen una parte de su sacerdocio. Su actividad pastoral en las fábricas o en el puerto les ocupa tres o cuatro días cerca de los trabajadores. Su apostolado consiste en servir y en hacerse gradualmente amigos de los rrabajadores, de todos y no simplemente de los trabajadores cam tólicos. No se trata de un apostolado de masa, sino de una acción individual. Su servicio es un servicio de sacerdotes, enviados por la Iglesia, en las fábricas.

Elegidos por el Arzobispado, los capellanes del trabajo se preparan para su misión en una sesión de estudios y de formación durante la cual se tratan y discuten de apostolado en el mundo del trabajo, se estudia el dogma, la pastoral y la sociologia. 
Desde que son capellanes del trabajo, estos sacerdotes se reưnen cada lunes para un corto retiro, 3 discusión de una ponencia y cursos de estudios. Cada mes presentan ma relación escrita sobre su sacerdocio en la fábrica.

Completando su servicio de ssistencia moral cerca de cada trabajador en particular, hay también grupos de fábrica de apostolado de la oracíon (100 en Génova), conferencias de fábrica de San Vicente de Pá́l (100 también en Génova).

Cada yez que pueden, estos sacerdotes celebran el domingo misa para los trabajadores. De todos modos, cada año organizan la vigilia pascual en las fábricas y retiros en Asís...

Además de este apostolado puramente religioso, los capellanes del Trabajo y la ONARMO practican la asistencia social: ayudan a los que buscan empleo, se ocupan de la asistencia sanitaria. Una escuela llevada por las Hermanas Franciscanas Misioneras está abierta en el cuadro de la ONARMO para los thijos de los obreros del puerto.

Los capellanes del Trabaio actúan en más de 200 empresas de la cium dad y de la provincia. Su trabajo consiste en tener contactos personales directos con los trabajadores de cualquier oficio; los capellanes del Trabajo en Génova totalizan 500 horas de apostolado por semana.

La asistencia moral que ofrecen en los diversos medios y en la wOficina central de coordinacion» comprende una media de mil visitas o con sultas por mes. En la mayoría de los casos, se trata de facilitar un empleo - de evitar despidos. Otra de sus principales preocupaciones consiste en sus esfuerzos por regularizar la situación de las uniones ilegítimas en los planos moral y jurídico. Se ocupan igualmente de colocar a los ancianos y a los niños en hospitales o en escuelas.

En el plano de la asistencia social en un año se les han presentado 26.800 casos, de los que 25.000 se han resuelio favorablemente.

La organización de las Conferencias de San Vicente de Pál alcanza a 78 empresas y agrupa a 2,000 miembros activos y auxiliares y ha efectuado 48.000 visitas anuales a domicilio y en los hospitales. Con este título se han gastado dos millones de liras. El servicio religioso reme cada domingo para la misa, en cinco capillas de fábrica, a unas mil personas. Las últimas estadísticas para la práctica del precepto pascual han registrado 35.000 presencias en la misa y 4.500 comuniones. En 20 empresas el oficio se ha celebrado durante el tiempo pascual por el Sr. Arzobispo. En un año en diversas empresas se han celebrado 250 misas el domingo y 132 en días feriados.

\section{El apostolado de un obispo}

El Sr. obispo de Casale Monferrato, Mons. José Angrisani, expresa así este su apostolado en la revista del Clero Italiano: 
"Comence hace catorce años y hoy puedo continuar, gracias a Dios, con el mismo sistema. Durante la Cuaresma voy tres dias a cada fabrica, y tengo cada día una breve conversación relighosomoral. Después, cuando las grandes ciudades, Turin y Génova, han comenzado a celebrar la misa en las fábricas y a distribuir la sagrada Comunión, mis sacerdotes han pedido hacer lo mismo en Casale, y hemos logrado la función pascual en la fábrica. Durante estos catorce años el clima encontrado en las fábricas ha sido diverso: cirma fascista, clima de guerrillas, de libertad casi incontrolada, de lucha de ideas y partidos. Una sola fábrica, que por decisión de la comisión interna obrera no quiso las conferencias cuaresmales, quebró y se cerró para siempre.

El que quiere ir libremente a las conferencias y a la Pascua va, y si no quiere, no. El porcentaje de los asistentes va del 50 al 70 y al 80 por 100. In algunas fábricas el concurso es total.

Yo preparo los temas de modo que estén atados entre sí orgánicamente. Los sacerdotes que van a las fábricas más pequeñas usan los mỉsmos esquemas. Nada de metafísica. Todo y solo Evangelio, confirmado con ejemplos y con reflexiones sacadas de la vida cotidiana.

Hemos establecido en tres empresas las Conferencias de San Vicente de Paul. Otra iniciativa consiste en la Jorrada anual de retiro para aquellos obreros que son más intimamente cristianos. Estas jornadas reunen a un centenar de los mejores y ayudan a formar la levadura que haga fermentar la masa para el bien.»

\section{HOLANDA}

El obispo de Haarlem, Mons. Huibers, acaba de lanzar esta forma de apostolado. Ha enviado a 28 sacerdotes a ejercer su ministerio en fábricas de la región industrial de ljmond, donde van a cuidar de 40 centros diferentes. Habitan todos en la misma casa, en la que los obreros les han constrúdo una capilla. Un sacerdote tiene el cargo nacional de estar en contacto con este apostolado y de coordinar la labor de estos sacerdotes.

En algunas ciudades los sacerdotes no van a las fábricas, pero atienden a los obreros de ellas en propios centros, donde los reúnen para círculos de estudio, retiros espirituales, etc. Así en Amsterdam, jesuítas, capuchinos y redentoristas se han repartido las fábricas para estas atenciones. Algo semejante acurre en Rotterdam.

\section{CANADA}

Ha comenzado esta experiencia en 1954 en el Canadá en la Compañia de Aluminio situada en Shawinigan, en la provincia de Québec, a petición industrial y con el pleno consentimiento del Obispo de Trois Rivières. Han sido encargados de ello dos sacerdotes del Centro de Servicio Social de dicha diocesis, Mons. Charles Edouard Bourgeois, fundador director del 
Instituto Psicosocial y de su apreciado ayudante, el Rvdo, D. Raynald Rivard, La prodigiosa actividad que estos dos sacerdotes han desarrollado en este Centro ha dado resultados tangibles, conocidos por especialistas del mundo entero.

No es una capellanía lo que desempeñan, sino sólo un servicio de consultas destinado a los obreros. La originalidad de su ministerio consiste en que es a la vez, e inseparablemente, sacerdotal, social y psicológico. No se desarrolla ninguna acción sindical ti política. No es el mienbro del sindicato o del partido como tal el que acude al sacerdote, sino el hombre, el cristiano, el esposo, el padre de familia, el trabajador, que tienen sus prom blemas cotidianos que desembrollar, para ponerse asi en orden, recobrar la paz interior y vivir humanamente, socialmente, cristianamente. El sacerdote consejero examina los hechos que le son presentados a la huz de su ciencia, la teologla, y de las diversas ciencias del hombre, que no le son extrañas.

Es consejero, repetimos, llamado a analizar problemas personales que tienen implicaciones psicológicas o sociales. No desenperia en ta fábrica el papel de párroco. Ministro de Dios, se queda plenamente en su actitud general, abriendo su inteligencia y su corazon a las aprensiones, dificultades, incomprensiones, inquietudes y angustias. Ayzda a ver claro, quiere derribar barreras, disipar desconfianzas. Las cuestiones puramente espirituales se dejan para los sacerdotes de la parroquia. Se preparan los caminos, se dispone a los sujetos a tener contacto con la parroquia.

Siendo el sacerdote en este caso especialista del servicio social y de la psicología, puede tener necesidad de acudir a otros especialistas; consejeros de orientación, psiquiatras, médicos. De hecho se han dado siete casos en el curso de dos años en que el sacerdote ha hecho un llamamiento a los conocimientos de seis especialistas reunidos, gracias a los cuales se han propuesto soluciones satisfactorias, a pesar de la gravedad de las cuestienes que resolver. Estos dos miembros de dicho Centro del Servicio Social cuentan con todo un equipo de técnicos de las relaciones humanas: por tanto, en su acción cotidiana están secundados sin complicaciones ni retrasos por especialistas muy cualificados.

La dirección de la empresa, que no es católica, ta dado permiso a los obreros y a los empleados para visitar a los sacerdotes consejeros durante el horario de trabajo, después de ponerse de acuerdo con el contramaestre. Desde la fundación de este servicio hasta el primero de enero de 1956, o sea en unos dos años, los dos sacerdotes han recibido unas 295 visizas, para la solución de problemas personales y familiares; 90 obreros han recurrido a la ciencia y a la experiencia de sus sacerdotes.

Se ha comprobado que la actividad de los dos sacerdotes ba contribuído poderosamente a crear en la fábrica una atmósfera de comprensión y de alegría y a poner en las almas el anhelo de Dios. El periódico de dicha empresa «Le Cables, en sa número de enero de 1956, refiere una vista del Sr. obispo de Trois Rivières hecha a los diversos departamentos de las dos fábricas de dicha empresa. Ha visitado a los obreros y empleados en 
medio de su tarea y ha sido recibido en todas partes con alegría y satisfacción. Al final dijo: «La presencia del crucifijo en cada departamento demuestra que tenéis el cuidado de Dios. Felicito a la empresa por las medidas tomadas para asegurar el bienestar de los trabajadores y para establecer el Servicio Social. Es wna convicción personal mia que una industria no se ha de preocupar solamente de sólidas bases industriales, sino de otros prow blemas de orden social, de dar un alma a su empresà.

\section{ALEMANIA}

En Munich, en el curso de estos últimos años, han aparecido dos realizaciones importantes de los católicos alemanes en el dominio del apostom lado obrero.

La primera, el movimiento de las comunicaciones de empresa, se remonta a 1946. Un grupo de seglares, animado por el P. Franz Prinz, S. J., cayendo en la cuenta de los problemas de la vida en la fábrica, se ha esforzado a la vez en reagrupar a los obretos católicos en el plano de la empresa, cuya influencia es profunda en ellos, y en asegurar la presencia misionera de la Iglesia en el seno del ambiente de trabajo. La comunidad de empresa tiene ante todo una función religiosa: pretende asegurar la formación religiosa de sus miembros por círculos de estudio y retiros, y llevar a la fábrica un testimonio esencialmente apostólico; pero, abierta a todos, acepta la colaboración de todos los hombres de buena voluntad, católicos o no.

Por otra parte, la comunidad de empresa tiene una formación social: invita a sus miembros a desarrollar su formación en este plano; sin tomar a su cuenta directamente las actividades temporales, pide a sus militantes que desarrollen acción social en el plano de las organizaciones existentes, en la empresa y en los sindicatos.

No quiere ser numerada como las otras organizaciones católicas, pero desea reagrupar, en su nivel, a todos los católicos activos, cualquiera que sea su pertenencia.

Desde su fundación, las comunidades de empresa se ban difundido en la diócesis de Munich y a través de Alemania, sobre todo en el Sur. Son una rama, todavía joven, pero extremadamente dinámica, de la Acción Católica Obrera en Alemania.

Más recientemente, el cardenal Wendel, arzobispo de Munich, ha tomado una decisión muy importante para el porvenir del apostolado obrero. A fin de 1955 nombró cinco consiliarios del trabajo: un franciscano, un capuchino, un redentorista y dos jesuítas.

Estos consiliarios se consagran enteramente al apostolado de los obreros en relación con el clero de las parroquias. En el sector que les es confiado, se esfuerzan por sacar militantes de empresa. En la medida de lo posible, penetran en las fábricas para hacer en ellas un trabajo misional, tener 
contacto con los obreros, discutir con elos sus problemas y aun, si las circunstancias lo permiten, organizar, durante los tiempos libres, remiones seguidas. Más particularmente encargados de la formación teligiosa y apostólica de los milivantes, organizan circulos de estudios y conferencias dum rante los ocios. Pero también pretenden abrir el acceso a los obrenos de todas las tendencias. Su accín ha de completar eficazmente ua de las comuvidades de empresa.

\section{INGLATERRA.}

\section{La mision industrial de Sheffield}

Transcribimos la narración de esta experiencia de la revista Intomations Catholiaues Iniermationales.

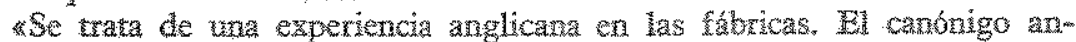
glicano Wickham es en Inglatera el que ha inagurado esta forma bien determinada de apostolado. Es capelín oficial anglicano de una de las tundiciones más importantes de la capital del acero. Su thbrica tiene cerca de 7.000 obreros. Es miembro del capitulo de la catedral de Sheffield y trabaja en estrecha unión con su obispo, que es un ardiente promotor de la Misión industrial en Inglaterra. Ello no deja de tener interés para los católicos.

Según el canónigo Wickbam, hay que establecer wna distinción entre la masa de los obreros y el personal de los cuadros.

Entre los directores, los jefes de servicio, los empleados, los técnicos y los contramaestres, es decir, el personal de las oficinas y de los cuadros, se encuentran gentes pertenecientes a iglesias diversas, anglicanos, metodistas, catolicos romanos, etc. El 10 por 100 de ellos dicen que son miembros de una iglesia, aunque muchos no lo son sino de nombre y apenas practican.

Ln la misma fábrica, en que trabaja el 85 por 100 del efectivo, eso es en las naves de fundición, laminería, forjas, talleres de máquinas y de acabado, etc, el porcentaje cae al 1 por 100 . Este residno de aislados comprende generalmente a fanáticos, adeptos de alguna pequeña secta. Wsto es ciertamente muy triste. Sin embargo, hay que advertir este hecho importante que difetencia la clase obrera inglesa de la de otros paises: gracias al régimen escolar inglés, todos estos hombres han recibido, siendo nitios, una instrucción biblica rudimentaria; han participado al menos en las oraciones de cada día en la escuela comunal, muchos han recuentado la escuela dominical, o el catecismo, hasta aproximadamente los doce años. Aun cuando prácticamente ninguno de ellos haya sido confirmado ni haya recibido la primera comunión, aunque todos hayan cesado de practicar, queda siendo verdad que cierto individualismo cristiano mantiene todavía en el trasfondo de ellos mismos una fe elemental. No hay un obrero entre mil que se diga ateo. Esta palabra es aún un insulto en el medio de los trabajadores. 


\section{Estructura parroquad y Misibn industrial}

Mútiples son los problemas creados por una cal sicuación. He acuí algumos gue son parcicularmente importantes.

Ante todo hay hata de sacerdotes. En Sheffield, dice el canonigo Wickham, hay un sacerdote para cada 9.000 almas, de modo que al pastor le es imposible conocer a todas sus ovejas persondmente. Es th extraño en medio de este rebaño inmenso. Esta crisis de efectivos es particularmente agula en loglaterra.

El organismo parroquial queda abrumado bajo al peso de nuevas responsabilidades impuestas a la liglesia por los cambios sociales que se multi" plican. La población, cada vez más flúda e inestable, no se arraiga ya en la parroguia: abreros y obreras, jovenes y viejos, rrabajan fuera de la parroquia, a yeces de noche y en domingo. Estos hombres así desarraigados se ven forzados a contentarse con un cristianismo individualista muy rudimentario que es la negación misma de la vida parrogulal. Así la antigua estructura tradicional está obligada a abrirse y a acoger la ayuda de nuevas empresas misioneras.

La doctrina biblica, la teología cristiana, la sociologia y la historia, piden que siempre, en todos los puntos críticos de la civilización, la iglesia asuma su responsabilidad no solo frente a los individuos y las familias, sino también frente a estructuras sociales e instiuciones de la ciudad que tienen una influencia tan considerable sobre los individuos y las familias. Por eso en Sheffield, en el seno de la industria del hierro y del acero, se ha desarrollado una misión muy especializada que, por los individuos, quiere alcanzar las estructuras del organismo industrial. Consiste en una capelania sui generis agregada a una acería. Hace nueve años se desarrolla esta experiencia bajo la dirección del canónigo Wickham. Comprende actualmente tres sacerdotes y una mujer, que consagran a ella todo su tiempo.

Los cometidos de la misión industrial. Para mayor claridad, el canónigo Wickham clasifica bajo los siguientes títulos los objetivos de su esfuerzo en Sheffield, aunque en realidad sean inseparables e interdependientes.

Conocer las personalidades responsables en una sociedad industrializada. Por sus misioneros y capellanes de fábrica la iglesia puede entrar en contacto personal con toda la jerarquía de los jefes de la industria metalúrgica, directores e industriales, responsables sindicales, presidentes y secretarios de los comités de los delegados de la mano de obra, etc. Así al fin la iglesia se hace presente en el seno de la sociedad industrializada moderna. Demasiado a menudo no conoce apenas a las gentes sino en cuanto maridos o mujeres, padres e hijos, practicantes o no, parroquianos responsables o no. No los conoce sino raramente en su relación con la comunidad, bajo el ángulo profesional o civico, en cuanto personas que desempeñan una elevada responsabilidad o ejercen una influencia profunda en una fábrica, en un consejo municipal, y por este hecho tienen a su cargo intereses espirituales consi- 
derables. Son, en efecto, estos hombres los que, en fin de cuentas, modelan las instituciones de la ciudad y por ellas millones de almas.

Vísita a los hombres en sus talleres. Tal es la ocupación cotidiana de los capellanes. Gracias a su contacto no sólo con los directores, sing tambiér con los consejos de taller y los comités de los delegados de la mano de obra, se hacen aceptar en todos los sectores de la labrica. Pueden ver a los hombres libremente en su medio de trabaio, hablarles, a veces discutir seriaw mente con ellos, muy frecuentemente cruzar algunas palabras o alguna ocurrencia amistosa. Lo importante es que el sacerdote esté en medio de ellos, que se interese por ellos y les ame.

Un punto importante hay que notar. Si los capellanes se esfuerzan por todos los medios por suscitar grupos de amästad y de discusióng se niegan a celebrar servicios religiosos, dice el canonigo anglicano Wickham, pues quieIen a todo precio matar esta idea de que la iglesia no sirve sino para hacer cantar cánticos y rezar padrenuestros, y que esto es todo lo gue le interesa.

Penetrar on los grupos de obreros. Una fábrica metalurgica comprende un cierto número de grupos bien determinados, nacidos de las necesidades de la vida industrial. En estos grupos cerrados es donde es menester que el capellán penetre a todo precio y se haga aceptar como amigo, guáa y pastor. En efecto, los contactos con los individuos no son generalmente fructuosos, ní aun posibles, sino donde el capellán ha sido aceptado por el grupo: un espíritu de cuerpo y un sentido celoso de la solidaridad son factores decisivos de la mentalidad obrera. En el seno de estos grupos y por ellos es donde el capellán ejerce una seria influencia y logra despertar a las almas. Pronto los hombres organizan ellos mismos. su prograna de reuniones y de discusiones. Estas reuniones comienzan a veces en la cantina, en cualquier otro sitio de reunión, se continúan después del trabajo del dia y a menudo acaban en el café. En los talleres importantes los hombres han establecido verdaderos comités donde están representados los diferentes grupos que tienen reuniones particulares.

Penetrar en los grupos profesionales (aprendices, responsables, sindicatos). Los aprendices forman una clase aparte en el seno del organismo industrial. Desde su llegada los capellanes los reúnen y los hablan del mundo en el que entran. Este primer contacto puede ser mantenido, porque los cam pellanes han logrado un sitio en los cursos complementarios que los nuevamente llegados han de seguir, un día por semana, durante dos años. Este derecho les ha sido conferido a la vez, por el servicio encargado en la fábrica de la formación de los aprendices y por el comité municipal de educación. Así los sacerdotes pueden organizar todo un programa de instrucción y de discusión, integrado en el plan general de formación de los jóvenes. Su enseñanza tiene un amplio campo: el trabajo, Cristo, la Biblia, la moral sexual, la política, el comunismo, etc.

No se limita a los aprendices la acción de los capellanes; se extiende también a los grupos responsables de la marcha de la fábrica. Les es necesario anudar relaciones sólidas con el cuerpo de los jefes del personal, con 
la asociación de los jefes de sectores, los consejos de taller, y los comités de la mano de obra. Gracias a esto pueden actuar en los consejos que deciden sobre la formacion de los jóvenes, en las conferencias de los directores y de los contramaestres, en las que frecuentemente se organizan por la Federación del Hierro y del Acero (los patronos) para los numerosos grupos que encierta la tábrica.

Están en fin los sindicatos. Los capellanes a menudo son invitados a las reuniones de los comités locales, que se tienen en cafés el sábado y el domingo. Relativamente pocos sindicatos van a las reuniones; pero all se encuentran los hombres cuya influencia orienta verdaderamente la acción sindical, aquellos cuyo sentido político está más despierto. Allt, en fin, se encuentran los militantes conunistas.

Naturalmente, el apostolado en medios semejantes requiere de parte de los capellanes todo un aprendizaje, pues la participación en todas estas conferencias y reuniones, la educación de los jovenes, la dirección de las discusiones religiosas, politicas, profesionales, requiere una suma considerable de conocimientos y de experiencia. Además, es menester que estos sacerdotes puedan descubrir en la enseñanza cristiana, y en la Biblia, principios que restablezcan en sus perspectivas espirituales y eternas los problemas industriales y sociales más modernos. Han de desenmascarar los errores del sistema presente y procurar una solución mejor.

Formar apóstoles seglares. La penetración cristiana en las fábricas no puede ser sino la obra de los seglares. El sacerdote es ciertamente muy importante para estimular esta penetración, para preparar el terreno, para mostrar bien que la iglesia está profundamente interesada por esta mision, pero es el seglar el que en su taller aporta el testimonio y hace penetrar así en ét a Cristo de una manera efectiva y continua. No hay ninguna duda respecto de esto. Lo cual quiere decir que el conetido más importante de la Misión industrial consiste en suscitar seglares decididos a dar un testimonio completo e inteligente. La Misión industrial necesita un cuerpo de seglares que puedan pensar de una manera «teológica», que tengan una concepción teológica de la industria, de la política, del mundo. Todos los esfuerzos de la Misión industrial no tienen en realidad otro fin que la formación teológica y espiritual de un núcleo de militantes seglares sólidamente equipados, dispersados en toda la fábrica, en todos los niveles, comprendido el de los sindicatos. Por eso, cada dos meses se organizan conferencias especiales sobre el cristianismo y la industria. Se dirigen a la selección; asisten a ellas los hombres mejor dotados, cualquiera sea su posición en la fábrica. Las conferencias se tienen en retiro y duran tres dias. A veces las invitaciones son enviadas en nombre de la fábrica, a veces los capellanes quedan autorizados para invitar a los hombres de su eleccion. Estas conferencias son de la más alta importancia.

Formar a los seminaristas. Diáconos y sacerdotes-obreros. Atraidos por el interés suscitado un poco en todas partes por la Misión industrial de Sheffield, un cierto número de seminaristas y de estudiantes de Teologia 
se ha entolado como peones por seis meses o un año. Esto forma parte de su formación pastoral. Varios desearan ser completamente obreros y bacerse ordenar como diáconos o sacerdotes, y wiwir y obrar como los sacerdotesobreros de Francia. Por el momento, los obispos anglicanos se oponer a estos deseos.»

\section{ESTADOS UNDOOS}

Mons. Fulton 3. Sheen, obispo auxiliar de New York, tan conocido por sus libros y campañas de radio y television y conversiones logradas, al hablar de los medios positivos para combative el comunismo, explica la función del capellán de industria.

"Otra forma de combatit al comunismo-dice- sezia nowbrando canellanes en todos los tipos y tamaños de la industria. La

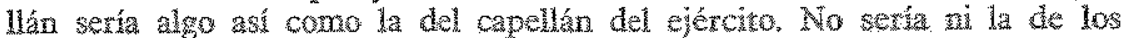

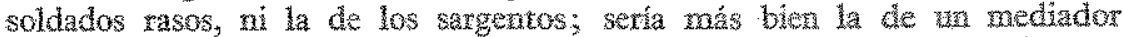
entre ambos, que obrarka siempre en beneticio de todo el servicio, de su orden y de su decoro. Como la agrupación más grande e importante de nuestra vida nacional es la industrial, no hay mocivo para que la religion abandone su pretensión, afimada con tanta contianza en los siglos primitvos, de dar instrucciones morales en materia de negocios. No podemos desm entendemos del hecho de que, cuando el individuo crea una nueva relacion humana en que gasta la mayoria de sus días, casi toda su semana, hay una necesidad especifica de ayudarle en uesa relación», y no aparte de ella.

A fin de que el capelán pueda obrar dentro de un grupo industrial, debe construir una iglesia muy cerca de la fábrica, donde los obreros y los directores, el capital y el trabajo, puedan practicar el culto, y atrender gue todos los que comen el mismo pan son ur solo cuexpo. Si hos hombres se hincaran de rodillas juntos, habria menos necesidad de que usaran sus punos los unos contra los otros. Pero las funciones del capellán no se limitarian a la iglesia de la fábrica. Así como los campamentos del ejército le asignan al capellán una oficina en el campamento, así también la industria le asigm naria un alojamiento en que podrían consultarlo libremente a todas horas tanto los obreros como los directores, porque no hay motivo para que las verjas de hierro de una fábrica le impidan disfrutat al obrero moderno de lo que disfrutaba el herrero de la aldea: el acceso a un sacerdote. 1ill capellán industrial no recibiría sueldo, ni dineto para gastos, de los accionistas, de los directores o de los obreros, sino solamente de su iglesia, a fin de estar libre de todo compromiso con una u otra parte.

A su debido tiempo, el capellán podría crear salas de lectura y clubs de debates y hasta organizar el culto de la fábrica. La ventaja suprema de éstas y otras funciones del capellán sería que los hombres quedarian organizados sobre una base distinta de la de la competencia.

M. 


\section{IV.- Crónica legislativa}

(Nowiembre 1956-febreto 1957)

\section{Nuevo régimen de despidos}

El Decreto de 26 de octubre de 1956 , publicado en el Boletin Oficial del 25 de diciembre del mismo ano, ha introducido modificaciones profundas en el régimen de despidos vigente hasta esa fecha, modificaciones que han suscitado variados y opuestos comentarios, tanto en la prensa como en las revistas profesionales. Con la intencion de orientar a nuestros lectores y contribuir a la divulgacion de medida de tanta trascendencia, vamos a exponer seguidamente los puntos esenciales del citado Decreto, anadiendo nuestra modesta opinión sobre las temidas consecuencias del mismo.

\section{I. - El hecho del despido}

En lo sucesivo, el empresario que quiera despedir a un obreto le dirigirá una carta fechada en la que consten las causas que tiene para romper el contrato de trabajo que los ligaba, siempre que éstas causas sean algunas de las expresadas en el art. 77 del texto refundido de la Ley de Contrato de Trabajo (26-1-1944) y sin necesidad de instruir el expediente previo que casi todas las reglamentaciones nacionales de trabajo exigian anteriormente para que quedaran acreditadas la comisión de faltas graves o muy graves por parte del obrero.

A primera vista parece que no hay más modificación que la supresión del expediente, requisito puramente formal que en la práctica no llenó las finalidades que el legislador le atribuyó al imponerlo. Su desaparición no debe ser considerada como una pérdida de garantías para una u otra parte. Especialmente los trabajadores, miradas las cosas con realismo, deberán sentir muly poco la supresión de un expediente en que su posición no era nada cómoda y a veces servía para agravarla más aún y prolongar las casi antomáticas suspensiones de empleo y sueldo que la incoación del mismo llevaba consigo en la mayoría de los casos. Decimos que ésta es la única innovación que aparece a primera vista en el art. 1.0 del Decreto que comentamos, porque en el fondo nos parece advertir otra reforma mucho más grave. No es otra que la posibilidad legal de que desaparezca en la práctica gran parte al menos de la gradación de faltas y sanciones establecida por las Reglamentaciones Nacionales de Trabajo. Estas dividian las faltas, por lo general, en tres grupos: leves, graves y muy graves, y paralelamente señalaban las sanciones que se podian adoptar atendiendo a la importancia y gravedad de la falta cometida, de tal manera que una falta leve o grave no podia ser corregida con la imposición de sanciones «muy graves». 
sino con las correspondientes a su grupo. El despido era la última de las sanciones muy graves y venia a ser como la pena de muerte en lo laboral, reservada para los casos extremos.

Esta gradación y matización de las faltas y sanciones no está recogida en el art. 77 del texto refundido de la Ley de Contrato de Trabajo, que sirve de fundamento trico a la carta de despido actual, segun el art. $1 .{ }^{\circ}$ del Decreto de 26 de octubre, por lo gue creemos posible legalmente que esta parte de las Reglamentaciones Nacionales de Trabajo haya sido derogada prácticamente. Veamos un ejemplo: el citado art. 77 dice que serán consideradas causas justas de despido: a) «las faltas reperidas e injustficadas de puntualida o de asistencia al trabajoy; por tanto, en el régimen actual, quien se retrase dos veces o falte dos veces, injustificadamente, al trabajo podrá ser despedido, mientras que antes dos faltas de puntudidad o de asistencia en un mes tenian la callíicación de leves y suta sanción no pasaba de un día o dos de haber. Ahora, en cambio, pueden ser sancionados con el despido.

Un detalle al parecer sin importancia, la texe en cambio muy grande. Me refiero a ia fecha de la carta del despido. El trabajador debe cerciorarse de que la fecha gue consta en la carta es la del dia en que él la recibe, y esto porque a partir de esta fecha erroieza a correr el plazo de quince dias hábiles que él tiene para acudir a la Magistratura de Trabajo. Como este plazo es de los llamados de caducidad, ni se prorroga ni se isterrumpe por nada. Si no se recurre contra el despido dentro del mismo, la Magistratura no puede examinar una demanda presentada fuera de plazo, aun cuando la razón esté enteramente de parte del despedido. Como se trata de quince dias hábiles, en las capitales de provincia, y dieciocho en los pueblos, hay que descontar de ellos los días festivos.

\section{II.-Consecuencias}

El hecho del despido se perfecciona por la entrega de la carta. La primera consecuencia, pues, para el trabajador que considere improcedente su despido, es la de acudir a la Magistratura de Trabajo, en el plazo antes citado, para que ésta intervenga, examine y juzgue si ha habiơ o no razón sum ficiente para proceder a el. La reclamación del obreto debe hacerse mediante demanda judicial. Cono no son muchos los trabajadores que están en condiciones de redactar una demanda por sí mismos, este requisito pide que acudan a la Organización Sindical y que los Servicios Jurídicos de ésta la preparen y entreguen al interesado para su presentación a la Magistratura de Trabajo. Esta convocará a las partes para la vista, celebrada en la forma ordinaria y dictará sentencia calificando el despido de procedente o improcedente. Desaparece la calificación de nulo antes existente, pues precisamente la nulidad se derivaba del incumplimiento de formalizar como requisito. previo el expediente en la Empresa, que ahora ha desaparecido. 
Un despido calificado de procedente hace firme la resolución de la Em* presa. El despido improcedente da lugar a las siguientes situaciones:

1) La Empresa quedará condenada a la readraisión del despedido o a darle la indemnización que el Magistrado fijje.

2) El derecho de opción para elegir entre la readmisión o la indemnización corresponde al empresario si tiene menos de 50 trabajadores fijos y al trabajador si la Empresa pasa de esa cantidad.

3) Este derecho de ópción deberá ejercitarse, por quien corresponda, ante la Magistratura, mediante comparecencia personal o por escrito, dentro de los cinco días siguientes a la firmeza del fallo recaído.

4) No obstante lo expresado en el punto segundo, el empresario con más de 50 trabajadores fijos podrá negat la readmisión al obrero que haya ejercitado en este sentido su derecho de opción, quedando entonces sujeto a las resultas de un incidente que, a instancias del obrero, formará la Magistratura de Trabajo y en el cual se sustituye la readmisión por una indemnización especial de «daños y perjuicios». Creemos encontrarnos ante un punto flojo del Decreto. Por un lado, en el caso de estas empresas se concede al trabajador la facultad de elegir entre la readmisión y la indemnización, y por el otro se da suficiente poder al empresario para invalidar este derecho. ¿No hubiera sido más lógico establecer que el derecho de opción corresponde siempre al empresario en todos los casos? Con el sistema actual, dada la cuantía que puede alcanzar esta indemnización especial, es cierto que los empresarios cuidarán mucho de despedir arbitrariamente a sus trabajadores, pero también puede ocurrir que bien manejadas por éstos las posibilidades legales se hagan pagar demasiado caro irregularidades en la conducta laboral que, sin llegar a ser estimadas causas justas de despido bagan, sin embargo, que la permanencia del obrero en la empresa sea molesta, incómoda o perjudicial para la producción e incluso para los demás compañeros de trabajo.

Producido el despido y su calfícación legal, ya hemos visto que todo ello puede derivar simplemente en una indemnización económica al obrero. El régimen actual regula tres indemnizaciones distintas.

1." Indemnización ordinaria por despido.-Se aplica a las empresas de menos de 50 trabajadores fijos y puede llegar como máximo hasta un año de salario. Por cierto que existe la creencia, muy general, de que para regular la cuantía de esta indemnización las Magistraturas tienen que adoptar la regla de abonar un mes por año de servicios en la empresa. Esta creencia es fundamentalmente errótea. El Magistrado fija la cuantía de la indemnización y valorando en conciencia diversos criterios que el Decreto de 26 de octubre enumera expresamente al tratar de las indemnizaciones especiales por «daños y perjuicios», pero que creemos igualmente aplicable a la indemnización ordinaria de que nos estamos ocupando. Estos criterios son: antigiedad en la empresa, cargas familiares del despedido y la facilidad o dificultad que tenga para encontrar otra colocación adecuada. Cada indemnización 
es considerada desde estos rres puntos de vista, y, por tatuto, wo solamentio no es auromática 1o avifocion de la popular regla del nes por ano, sino que el criterio de la antiguedad puede ser modficado por los oros dos de terminando una disminución o aumento de la indemnizactón con indeper dencia de la andigüedad en la ampresa.

2." Indemnización por salurios. - Tiene el caracter de indemizacion complementaria de la ordinaria o extraordinaria en los despidos declarados improcedentes y equivale al importe de los jomales que hubiera devengam do y no percibido el trabajabor durante 12 sustanciación det proceso ante la Magistratura. Posee cierto parecido con el abono de los jornales del tiempo de suspensión de empleo y sueldo del sistena antiguo, pero se durerencia de la misma, $y$ en esto se ha ganado mucho, co que su aplicacron es arinto mática y no, como antes, potestativa del Magistrado a peticion de parte.

3. Indemmizacion extrachinonia por doños y perjucios, - Cono ya se ha dicho, es una indemnización especial por su chantia y la torma que exige para determinarse, concedida a aquelios trabajadores de empresas mayores de 50 obreros fijos que, habiendo sido calificado su despido de improcedente, optan por la readmisión en la empresa y'ésta, o se niega a readmitilos, o lo hace modificando las condiciones del trabajo. En este caso, el tram bajador acude de nuevo a la Magistratura y por ésta, comprobado el hecho de la no readmisión o de la modificación de las condiciones de trabajo, se incoa de oficio un incidente de daños y perjuicios que termina en la fijación de una indemnización especial, cuya cuantía no puede ser inferior a seis meses de salarios, ni superior a cuatro años. Al hablar de esta indemnización especial es cuanto el Decreto de 26 de octubre señala los tres criterios, antes citados, que han de servir al Magistrado para fijarla.

Esta indemnización, pues, puede alcanzar cifras extraordinarias y creemos que la intención del Legislador es la de que sirva de freno a una posible epidemia de despidos facilitada por la supresión del expediente previo y el rescate por las empresas de la facultad de proceder por si mismas, unilateralmente, a la rescisión del contrato de trabajo. Supuesto esto, que en la práctica ha mostrado ser un medio eficaz para impedir el crecimiento vertiginoso de los despidos, ¿qué necesidad hay de mantener el hipotético derecho de opción en las empresas de mós de 50 trabajadores fijos a favor del obrero? Se hubieran evitado dilaciones, siempre perjudiciales al trabajador, concediendo simplemente a la Magistratura facultades más amplias en materia de indemnización ordinaria y quizá no se produjera la impresión poco agrada ble que produce el incumplimiento por las empresas de lo que puede llamarse sentencia de readmisión.

Por otra parte, se sostiene legalmente el criterio acertado, al disponer en el art. 12 del Decreto que en todos los casos en que por sentencia se declare improcedente el despido de alguno de aquellos productores que desempeñen destinos para los que sea preciso ingresar al servicio de las empresas por oposición o concurso-oposición, conforme a las reglamentaciones 
de trabajo o a los Reglamentos o Estatutos particulares de aquéllas, y los interesados opten por la readwisión, será śsta obligada para las empresan, sin que proceda la indemuzación de datios y perjuicios.

En conjunto el Decreto, a nuestro juicio, supone un avance sobre el anriguo sistema, pues, sin perjuicio de of tecer garantias suficientes de permanencia en el empleo a todos aquellos trabajadores que cumplan fielmente sus obligaciones laborales, garantías constituidas por la exigencia de alegar y probar causa justa para el despido y el otorgamiento de las indemnizaciones expuestas para los casos de despido arbitranio, significa tambien una mayor facilidad para romper aquellos contratos de trabojo en los que por parte del crabajador no se cumpla con los requisitos minimos de fideliad, disciplina. y rendimiento a gue se obligaron al firmarlo.

S., T. C. 


\section{REVISTA DE REVISTAS}

\section{BLGAS}

\section{AU SERVYCE DU CLERGE RURAI}

L. Batatile: En paroisse indifferente (En parroguia indíterente). Núma. 1, páginas 9-18.--Se acentua la descristianización de las grandes ciudades. La práctica religiosa (misa dominical) en Bruselas es del 26,3 por 100; en Amberes, del 31,7 por 100. O sea que en Bruselas no van a misis el 73,7 por 100 de los obligados, $y$ en Amberes, el 68,3 por 100. En Charleroi no asisten el 82 por 100; en Mons, el 77 por 100 ; en Soignies, el 74 por 100 ; en Lieja, el 71 por 100 . En la parte rural de Brabante $y$ del Este de Valonia solo practican regularmente el 50,69 por 100 de los jóvenes de dieciséts a veinticinco años. Se clasifican como parroquias cristianas aquellas en las que practican por lo menos el 45 por 100 ; si no se llega a esa cifra, se llaman parroquias indiferentes; un cierto porcentaje practica irregularmente; el conjunto queda fiel a los grandes actos religiosos de la vida: bautismo, comunión solemne, matrimonio, funeral religioso. Ante la indiferencia de su parroquia, el cura se sentirá a merudo impotente. Las rescciones sexán mauy diferentes. Algunos se dejan ganar por el derrotismo y se desaniman. Otros, sobre todo si notan que su acción no es estéril, conservan todo su ardor y voluntad para intentar lo imposible para vivificar su parroquia; pero todos experimentan la dificultad de la tarea, sobre todo por sentirse áslados. Se puede formar al equipo sacerdotal con sacerdotes vecinos. Hay que renovar la pastoral, pues las poblaw ciones han evolucionado de tal manera que el ministerio tradicional aparece inasum ficiente. La doble tarea consiste en hacex una comunidad de verdaderos cristianos y conducir al redil a las ovejas descarriadas. Hay que formar, pues, verdaderos cristianos por una evangelización profunda, por un cristianismo en toda la vida humana y una verdadera comunidad de cristianos, con la participación activa ene la misa y en la fracción del pan. Ello le ayudará para la otra tarea de enderezar a los descarriados por el trabajo de los seglares y militantes.

\section{LES CAHIERS RURAUX}

JaN VanHovtvinck: Natalité urbaine et natalité murale en Belgique (Natalidad urbana y ratalidad rural en Bélgica). Núm. 1, págs. 3-17.-Es un extracto de un largo trabajo presentado para tesis en la Universidad Catolica de Lovaina. Se sigue 
12 evolución de la población en el país fiamenco, en el país valón y en zruselas, y en cada sitio se hacen tres distinciones: grandes ciudades, pequeñas ciudades, pueblos. En cuanto a la natalidad en Flandes, en 1952 , por mil habitantes, era de 13,$24 ; 16,74$ y 18,59 , respectivamente; se ve, pues, cóno la rataldad es superioe en los pueblos y hay más en las ciudades pegueñas que en las grandes; en Valonia, las cifras eran en la misma fecha 13,$48 ; 14,68$ y 16,24 ; se ve, pues, que hay zás natalidad en Fundes que ex Valonia; en Bruselas, la natalidad fué de 11,28; por tanto, la natalidad más baja se encuentra en la capital. La tasa de fecumdidad, o sea la tasa de nacimientos por cada mil mujeres en edád de procrear, fué, en Flandes: 59,$45 ; 81,14 ; 91,32$; en Valonia: 62,$35 ; 73,21 ; 81,82 ;$ ex Bruselas: 50,41. En 1947, en Flandes, el nímero medio de hijos por familia faé, en las grandes ciudades, 1,68; en las pequeñas ciudades, 2,51; en los pueblos, 2,94. En Valonia, respectivamente, 1,$37 ; 1,61 ; 2,14$. En Bruselas, 1,34. Se ve, pues, que en las grandes y pequẽas ciudades no se asegura el reernplazamiento de la pobla ción; en Valonia, la pequena ciudad se acerca más a la grande que al campo; ex Flandes, al revés. Examina liego el axtot las causas estructurales, o sea las causas que provienen de la diferencia de composicion de la población ex las ciudades y en los pueblos. En cuanto a las causas no estructurales, estudia un cierto número de factores sociales y psicologicos que pueden influenciar los nacimientos, ya que los factores fisicos son inciertos y discutibles. En especial se detiene en estudiar los niveles de vida y la capilaridad social: cuanto mayor es el nivel de vida y mayor la capilaridad social, o sea la posibilidad de elevarse en la escala social, tanto es menor la natalidad; y en las ciudades es mayor la capilaridad y mucho más los servicios de comodidad a disposición de la población; aun en el mismo campo, la natalidad es mayor en las tierras menos fértiles que en las fértiles. Así, en Flandes, la natalidad en las regiones menos fértiles es de 20,70 por mil habitantes, y de 16,87 en las más fértiles; en Valonia, respectivamente, 18,12 y 14,85 .

\section{FRANCESAS}

\section{LA DOCUMENTATION CATHOLIQUE}

MONS. RENARD: Christianisme et progrès technique (Cristianismo y progreso técnico). 9 diclembre 1956; págs. 1579-1589. - Es una conferencia del obispo de Versalles a los consiliarios del Liceo reunidos en sesión nacional en París. Se recalca la característica de nuestra época, que es ciertamente el progreso técnico; su desarrollo plantea un problema al cristianismo, como todo to que es profundamente humano. Se examinan estos caracteres de la técnica: es positiva, colectiva, antropocéntrica, alcanza al hombre, trabaja al hombre, está en las manos y en el cerebro del hombre, y nada humano puede ser extraño al cristianismo. Quicrase o no, cristianismo y técnica se enfrentạn. Se considera luego la técnica como una creación divina prolongada por la zazón humana; Dios le ha dado este poder, ignorado por el mismo hombre hasta el siglo XX; Dios ha incluido en el mundo el potencial eléctrico y atómico. Luego se prueba la afirmación de que el técnico no es la más elevada estatura del hombre; el cristianismo pide al hombre que respete la escala de los valores humanos, y al hombre técnico no lo es todo. Luego se explica cómo la técnica crea una mentalidad difícilmente accesible a la mentalidad cristiana y cómo no sera cosa fácil astumir cristianamente el progreso téc- 
thoo. El progreso tecrico de si es inditerente al progreso moral y rejtgioso. No hay que confundir el progreso técnico con el progreso bumano. Pero d crizta nismo $n o$ puede quedar indiferente al progteso técnico, pues es obra del hombre y reacciona sobre el hombre de toda manera. Fintalmente, se esbozan algunas if neas de solucínn, sin pesimusmo senil ni optimismo pueril: los crastikno kan de estar presentes a las itivestigaciones ténicas; hay que cultivar el sentido del hombre y el sentido del misterio; el sacendote ha de dar testimonio entre los hombres de que, además del universo material y técrico, existe el universo ce ta caridad, del espiritu y de Dios, al cual se ha consagrado. Hay que presentar a Cristo a los 320.000 alumnos de la técnaç en los cursos y circulos de estudio, san olvidar a más de 400.000 aprendices.

\section{LA REVUE DES DEUX MONDES}

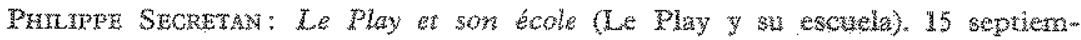
bre 1956; págs. 310-321.-E nombre de este justre sabio trancts desde hace cincuenta años ha sido borrado poco a poco de los manuales oficiales de exseãanza, olvidado por todos los que tienen el oficio de escribir. Los diccionarios no le conzsagran sino breves palabras. El articulista señala cómo, para darse cuenta de la influencia ejercida por Le Play sobre la formación del pensamiento francés, sobre el desarrollo de la ciencia histórica, sobre la creación de la sociologia, hay que releer a Tocqueville, Taine, Sainte-Beuve o Alberto Sorel. Se hace notar que para saber el rango en que lo colocan hoy los sociologos extranjeros hay que ir al extranjero a buscar la documentación y los testimonios. Le Play es designado como uno de los pensadores más notables de su época y como uno de los historiadores más clarividentes de su tiempo. Con todo, en Francia, la escuela de Le play no ha quedado inactiva, sino que sin interrupción se ha desarrollado por los caminos abiertos por su fundador a la ciencia social. La Sociedad de Economí y de Cien-m cias sociales ha celebrado ex 1956 el centenario de su fundacion por Le Play; y en la revista de esta institución, Etudes Saciales, se honra constantemente ta memoria de Le Play y se perpetúan las honorables tradiciones de independencia in telectual. Pero la escuela de Le Play ha sido tendenciosamente presentada como caducada, y lo mismo sus enserianzas; sus principios han sido tenidos como reaccionarios en los medios en que, por los favores que dispensa, el Estado ejerce una influencia y un control. En este artículo se dan a conocer las grandes etapas de la brillante carrera que le valió los títulos y honores más exvidiables. Se hacen resaltar sus tres cualidades relevantes: la eminente variedad de sus dones, la prew coz madurez de su juicio, la fuerza de su carácter. Le Play concibió que el método más preciso, el más científico, el más fecundo, era el de las monografias, a las que da un cuadro, un plan y un orden que hacen aparecer los hechos mảs reveladores y significativos. Se señala la elaboración de su obra en seis volúmenes sobre los obreros europeos; la de sus obras sobre los obreros de los dos mundos; sus tres tomos sobre la reforma social, escritos a petición de Napoleón III. Fué también un escritor politico, pero se mostró hostil a la lucha cruel y vana de los partidos. Le Play murió pobre y no tuvo dinero sino en la medida en que los recursos materiales le permitían realizar más eficazmente la tarea que se tabia asignado. Finalmente, el autor se pregunta si las circunstancias actuales no sor bastante graves para que otros hombres, hoy, de cualquier horizonte político de que pengan, rem conozcan en él a uno de los maestros en los que hay que inspirarse para volvet 
a encontrar el secreto de wa gobiemo que no tenga por fin y término la efunitón de sangre.

\section{MASSES OUVRTERES}

Fatre VINCENT: Catéchèse at monde technique (Catequesis y mundo técrico). Junio y julio-agosto 1956; pags. 6-19 y 27-39.-Se trata de una conferencia dada a consitiarios de escuelas técnicas convocados por la $\mathrm{J}$. O. C. El objeto de este estudio tho es describir una vez mós este fenómeno sociológico: el advenimiento acelerado de una nueva forma de civilizacion llamada stécnicas, sus incidencias en el plano de la vida adulta y de la escolaridad de los jóvenes, los problemas muy grayes que se plantean así en el plano de la organización de los esfuerzos catequísticos de la Iglesia. No se trata tampoco de analizar la psicología de los jóvenes que frecuentan las enserianzas técnicas, la mentalidad del conjuxato de los adolescentes del munato moderno, que es más y más una mentalidad técrica. Todo eso no es rás que un dato preliminar respecto del mensaje cristiano mismo, en sus aspectos más centrales, en su presentación sin eqzínocos a los adolescentes de este medio técnico. Por eso, el propósito es deducir las perspectivas de una catequesis, o más bien proponer algunos puntos o jalones por donde parece que ha de pasar el difícil sendero de una educación de la fe en el medio técnico. La primera parte intenta manifestar los caracteres de una permanente acción de base precatequética, su necesidad y fin, sus métodos principales, los equivocos que hay que evitar; en esta pedagogía precatequética hay que tener en cuenta la experiencia del sentido de la persona, de la comuxidad, del don de sí, de la libertad espiritual, la educación para el esfuerzo y la esperanza, el valor del silencio y de la admiración. En la segunda parte se esboza una zeflexión sobre los ejes de toda catequesis en función de lo que Dios nos revela de su misterioso designio y de to que creemos que conocemos de la mentalidad técnica; así se va reflexionando sobre el sentido cristiano del misterio, el seatido de Dios, el dogma de la Creación, la concepción cristiana de la materia, del cuerpo y del trabajo, visión cristiana de la historia y del progreso.

\section{ECONOMIE ET HUMANISME}

Th. Cardonnez: Rour une société sans classes (Para ura socicdad sin clases). Enero-febrero 1956; págs. 5-13.-Este artículo, para ser bien interpretado, se ha de situar en las perspectivas en que ha sido pensado y escrito. A pesar de sus divergencias, las ideologías capitalistas y soviéticas que inspiran actualmente los poderes publicos están de acuerdo en un punto esencial: no ven en el hombre más que un elemento de la naturaleza, que no sobrepasa el orden de las cosas. Fl autor hace un análisis critico del régimen de provecho, del que muestra sus dificultades sin solución; si no se aplica a un análisis semejante de las estructuras soviéticas no es porque desconozca sus peligros, sino porque se reserva el tema para otro artículo. La economía humana tiene por fin el bien total de todos los hombres por la valorización total del universo al servicio de la persona. No es una humanización de la economía por lo social, lo cual no es más que un paliativo z no va a las raices del mal. El derecho de la humanidad sobre el uniterso ha de ser un 
derecho para todo hombre de acceso a las riquezas elementales, esto es, al trabajo y a la seguridad. Los horbores han de ser tratados no en régimen pateradulata, sino como zxayores; las responzabilidades del poder basadas sobre la riqueza mam nifiestan la injusticia de una sociedad. Todas las clases sociales bav de poder dar selecciones. Una sociedad sin clases no es ma sociedad sin jerarduta ni indiferenciada, sino una sociedad sin privilegios, fundada sobre la abundancia, en la participación en las responsablidades y en el llamamiento a lo que hay de grande en el hombre. Se impone una jerarqua de las necesidades. El hombre esta hecho para darse entero en comunión con los otros, y wma sociedad wumana ha de dar una respuesta a esta necesidad de don. Hay que pasar de la falsulabertad a la verdadera libertad, que es dinámica $y$ se conguista sin cesas.

J. Y. Jow : Signification de NAthisme (Significación del ateismo). Mayo-junio 1956; páts. 195-207. - Dl proceso de la idea de Dios $y$ ta profanización del mundo son incortestablemente caractertsticas eserciales del mudo moderno. Vam rias actitudes son posibles ante este ferómeno: una condenación pura y simple - un esfuerzo por descubrir a aportación positiva. Fin este estudio se sigue la ultima actitud. Se plantea el problema de saber cóno manteniéndose al nivel del mundo, tal como existe ante nuestros ojos, es posibie mantener una relación con Dios. El ateísmo contemporáneo ha de conducir a la conciencia de los creyertes a una mejor inteligencia de Dios. Si el ateismo refuzado por los filósofos sobrevive a estas refutaciones es porque no es sólo un sistema ideal, sino porque surge de una situación histótica; zsí, no se puede refuzar sino por un pensaniento fllow sófico hecho práctico. Hace siglos, las relaciones entre el hombre y la naturaleza har cambiado: de una concepción sagrada y religiosa del kxundo creado se ha pasado a una concepción protana. El bombre descubre la opacidad del mundo y se descubre a sí mismo solitario; la técnica es puramente humana y no conduce a Dios. Se ha pedido a la ciencia gue desempeñe un papel redentor, pero este absoluto de la ciencia aparece como ilusorio; el mundo ya no es el espejo de Dios; se hace cada vez más el espejo del hombre; estamos ex un proceso de ateización. Algunas instancias del ateísmo son valederas para una conciencia creyente. E1 autor enumera tres: 1) El rechazo de lo absoluto. Este rechazo no es la divinización del hombre, sino el rechazo de esta divinización en la conciencia del carácter limitado del hombre; ningún valor absoluto existe ni en el hombre ni en la historia ni en la naturaleza, y la afirmación de esta finitud del hombre tiene que retenerse. 2) La reconquista de la libertad. Esta no es posible en ateísmo sino cuando el hombre no se sitúa en ningún absoluto. Esta lbertad no es capricho, sino un llamamiento a la responsabilidad y al trabajo, pues en un mundo inacabado la libertad se expresa por una obra de humanización y de racionalización; pero este mundo es sólo humano, y Dios está más allá. Una tal concepción de la libertad repercute sobre las relaciones entre los hombres: el verdadero compañerismo se hace un compañerismo de trabajo. Queda así sobrepasada la actitud Adealista; la libertad del hombre pesa en la historia, mas para tareas nunca acabadas. Esta definición del hombre por la acción, zdeja la posibilidad de una contempláción? 3) La profanización del mundo medieval. Significa que en este mundo nada puede fundar una contemplación, pero dejar de hacer sagrado al mundo puede significar también exorcizar toda idolatria, y hay maneras de hablar de Dios que acaban por ocultarle; Dios se sitúa más allá del mundo, y el creyente ha de probar que lo humano no absorba la totalidad del hombre; el ateismo se ha de sobrepasar más que refutar. 
3. M. ALBESTM: Croissance démographique et dételoppement économique (Crecimiento demográfico y desarrollo econonico). Julo-agosto 1056 ; págs. 310 317. - En los paises subdesarollados, in población anmene más aprisa que la produccion; de donde la gereralización del convo de los nachmientos, que se presenta como ol medio de resolver el problema del desarrollo economico; pero el tazonamiento es falaz. La esterilidad voluntara no permite la elevación rápida de los aiveles que se promete, sino que frena $y$ bloquea el desarrollo econónico más que to facilita. Una baja de la natalidad no tiene efecto sobre el crecimiento dem mografico sino a largo plazo, y no resuelve tada, ni resuelve sobre todo el equilibrio entre necesicades y recursos. La esterilidad no estimula el ahorro, antes obra contra el desarrollo económico, prepara el hundimiento de las antiguas civilizaciones y araplifica el desorden existente, sin facilitar la aparición de una nueva civilización. Se pueden considerar métodos aceptables y educativos para frenar la natalidad, pero hay que emplearlos con discernimiento. El estancamiento demom grático engendra el estancamiento económico $y$ produce la disminución de las inversiones, ractores del progreso económico. I esterilidad voluntaria no es el adecuado remedio para la miseria mundial, a la que la generosidad de los páses desarrolados ha de encontrar una salida.

\section{HOLANDESA}

\section{SOCIAAL KOMPAS}

J. DELLEpoort: Sociographisch onderzoek over priesterroepingen in Nederland (Descripción sociográfica de las vocaciones sacerdotales en Holanda). Año $I_{\text {, }}$ número 3, págs. 1-6-Comienza el autor por ana mirada sobre el número de las 7ocaciones con algunas consideraciones sobre estas cifras. La penuria de sacerdotes en los países vecinos crea múltiples dificultades. ¿Se está expuesto en Holanda al mismo retroceso? Dos factores determinan el número requerido para el clero: las ocupaciones juzgadas indispensables y un empleo racional del tiempo y de las fuerzas disponibles. Este doble criterio, el indispensable y el racional, encierra un elemento personal y subjetivo. En cuanto al primer punto, en el cumplimiento de los deberes habrá que tener en cuenta inevitablemente la manera como uno se aplica a ellos, por una parte, y por otra, una distribución de las tareas y la tendencia hacia la especialización que se manifiesta en las obras pastorales. En cuanto al segundo punto, es decir, el trabajo sacerdotal, en algunos sectores el clero está sobrecargado; en orros sectores, el rendimiento del trabajo sacerdotal es sin eficacia. Se hace la siguiente observación respecto de Holanda: se oyen lamentos, sin que sean alarmantes, respecto de la penuria de elementos jóvenes en la cura de almas. Tomando como punto de partida, para el cálculo de las necesidades en la acción pastoral futura, la relación existente entre el número de los católicos en Holanda y el número de los sacerdotes con cura de almas, 1,04 por mil católicos, se tendrá una idea de la necesidad minima. Consultando la cifra de la densidad de los sacerdotes junto con el cálculo aproximado del aumento del número de católicos, el autor pronostica la cifra de sacerdotes para 1980. El Instituto Católico de Investigaciones Social-Eclesiásticas estima que el total de los católicos alcanzará entonces alrededor de cinco millones. Se tendrá, pues, necesidad de 5.200 sacerdotes para el ministerio sacerdotal. En 1951 habia 4,100. De este total habrá 
que sustraer, entre 1951 y 1980,2900 , que sexán eliminados por 1a muerte, vejez,

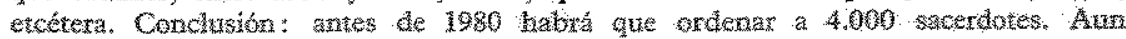

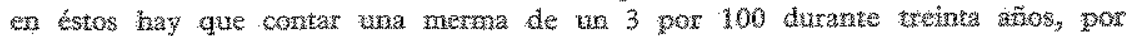
donde 4.20 ordenaciones serán de urgente necesidad, o sea 137 por año. Woy se ordenan 80 , por lo que esta base se ha de ampliar de manera considertable la

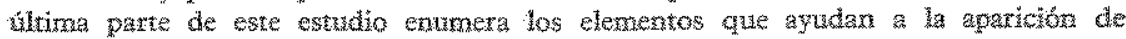
una vocación sacerdotal.

W. SToor, O. F. M.: Enkele beschow ewingen ower de aunpossing wan de zielsorg an de noden waw onze tijd (Algunas consideraciones sobre la adaptación de

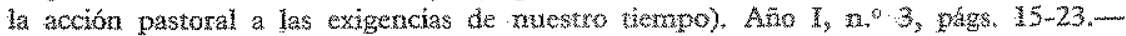
La acción pastoral, si ha de ser eficaz, ha de tener en cuenta ta stutacion psicosocial de los tales. Su actitud arte la fe esta ex efecto, en wratgran medida, condicionada por sus diversos stipos de xeacción» social. El atutor decribe sel tipo de reacción social propio del fiel metido en el proceso de unbanzación. Caracm terística de este proceso es el relajamiento de los lazos personales con provecho de las relaciones torganizadas», que se multiplican y se estrechan. Segun el modo de reaccion a la organizacion social, dos categorias principales se proden netamerate discennir: el burgués y el rabajador no cualificado. Se describen estas dos catem gorias y las subcategorias más importantes determinadas segun su «tipo especifico de reacción social. En seguida se estudia la cuestión de saber en guế medida la acción pastoral, tanto en el interior como en el exterior de la iglesia, es adaptada a la situación social. La conclusión quiere demostrar la importancia y la necesidad de un apostolado seglar que de manera adecuada tenga corno eje esta situación.

\section{ITALIANA}

\section{VITA E PENSHERO}

F. VITo: I ropporti fra economia e monale nellordine pratico (Las relaciones entre economía y motal en el orden práctico). Septiembre 1956; págs. 586-594.-Se reproduce la primera pare de la lección del autor en la Sernana Social Italiana, que en 1956 se dedicó al tema de la vida económica y orden moxal. Se explican las razones por las que se aspira a un orden social mejor, que son las dos guerras y el ritmo veloz de las innovaciones técnicas; se piden reformas en todos los campos y las proputestas incluyen un implicito reclamo de los valores morales, yra que las reformas e innovaciones no pueden dar resultado sin atra sentido moral elevado en los que han de prepararlas y ejecutarlas. Se trata de saber si la ley moral, a la caue está sometida la actividad humana, haya de detenerse o no en los confines de la esfera económica, esto es, si la norma moral tiene validez aun para las relaciones económicas, o si éstas están sustraidas a su irxperio por estar gobernadas por la sola búsqueda del éxito. La respuesta no es dudosa: la unidad del acto humano, por su naturaleza libre y responsable, impide que se concibax sectores de actividad cono existentes fuera del orden moral. Ante todo, se disipan algunos equívocos: no es exacto que una accion deje de ser moralnache aprobable sólo porque conduzca a realizar una ganancia o a obtener una ventaja material; es inexacto gue si un sujeto realiza una ganancia ha de haber necesariamente otros que, como consecuencia, sufren una pérdida; se invalida la doctrina insidiosa sem 
gün ta cual someter a la norma moral la actividad economica significa coartar todo estimulo y paralizar toda iniciativa y anular los beneficios etectiwos de la emula cón. La observancia de la moma moral supone negativametate que las venuajas materiales han de respetar los intereses de los otros y de la sociedad entera $y$, positivamente, el winculo moral que une a los miemoros de la sociedad prescribe 2 cada tno que ponga actos susceptibles de ayudar a los otros. Se reconoce que el imperativo moral sobre la actividad económica abre una problemática complefa y dificil por causa de los múltiples elementos en juego. Nunca se recorxendará to suficiente la colaboración entre el economista y al moralista. El attor investiga ante todo cuáles sean las repercusiones sobre la economía, según que el comportamiento de cada uno se oriente de acuerdo con los principios morales o con indiserencia respecto de los mismos. Fn esta primera parte de su conferencia se hacen aplicaciones a los problemas morales de la desvalorización monetaria, al manejo de los fondos públicos y a los grupos económicos.

\section{UNESCO}

\section{IMPACT, SCIENCE ET SOCTETE}

ALEXANDer KING: La science et l'évolution de lindustrie: phase sociale (La ciencia y la evolución de la industria: fase social). Marzo 1956; págs. 3-37.-1n novaciones sensacionales, como la producción de electricidad a partir de la energía nuclear o control automático de la producción, nos inclinan a pensar que estamos en trance de vivir una nueva revolución industrial. Si se examinan los hechos de más cerca, se ve que en realidad los cambios espectaculares a los que asistimos son el efecto de un proceso evolutivo cuyos orígenes se remontan a la segunda mitad del siglo XVIII. Atravesamos actualmente la tercera fase de la revolución industrial, fase en la cual la complejidad del descubrimiento y de la invención es tal que plantea problemas psicológicos, sociales y de organización, que a su vez influyen sobre la estructura de la industria. En esta tercera fase, el papel que incumbe a las ciencias sociales es quizás más importante todaviáa que el de las ciencias exactas y de la tecnología. Se da mucha importancia a la unión de los centros de investigación científica con la industria, aportándose ejemplos muy interesantes de Estados Unidos, que muestran la necesidad de la divulgación de los conocimientos científicos, que necesita sus propios instrumentos. Uno de los rasgos más impresionantes de la industria moderna es la importancia creciente que reviste en ella el factor humano. No todos están todavía convencidos de la utilidad de las investigaciones sobre los factores humanos; pero queda demostrado que las ciencias sociales en muchos aspectos pueden ayudar a la industria. Grandes tareas aguardan al especialista en ciencias sociales, las cuales, en el estado actual, apenas pueden hacer otra cosa que plantear los problemas; son problemas temibles, y la elaboración de los métodos nuevos que exigirá suz solución es una taréa digna de los espiritus más brillantes.

MARTIN BRUGAROLA, S. I. 


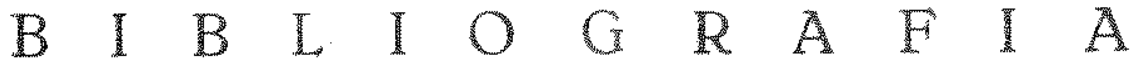

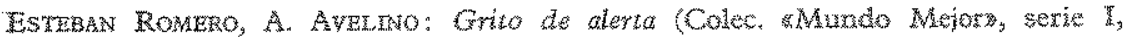
vol. 1). Madrid, Euramérica, S. A., 1956; 196 páas. En rústica, 35 ptas.

Morcinlo, Casmmiro (Arzobispo de Zaxagoza): Cristo en la fábrica (Colec. \&Muna do Mejorn, serie IV, vol, 1). Madrid, Eliramerica, S. An. 1956; 178 págs. En rústica, 35 ptas.

Estrebar Romero, A. AvEL pronunciadas para el personal del Instituto Nacional de Estadistica. Madrid, $1956 ; 152$ págs.

Sacerdotes y seghares (Colec. «Mundo Mejor», serie VI, vol. 3). Madrid, Euramérica, S. A., 1956; 218 págs. En rústica, 35 ptas.

FERNÁNDez de Castro, IGNacio: Del Patemalismo a la fusticia Social (Colección \&Mundo Mejors, serie IV, vol. 2). Madrid, Euramérica, S. An, 1956; 182 paginas. En rústica, 35 ptas.

Bajo el epígrafe genera1, "Colección Mundo Mejor», vamos a dar a conocer algunos de los ejemplares aparecidos en la colección. Comencemos por el libro que inangura la colección, Hacia un Mundo Mejor, que lanza Euramérica. Grito de alerta, es una presentación histórico-informativa de cuanto al movimiento se refiere: el pensamiento de Pí XII, en sus documentos, principalmente en los dos mensajes que dieron pie para la predicación de la cruzada: EExhortación a los fieles de Roma» (10-11-52) y discurso del 12 de octubre del mismo año, ex su proclamación al mundo católico. Figuran después los capitulos propiamente informativos sobre el desarrollo del «Mundo Mejor», principalmente en Italia y España. El esquema de las «Ejercitaciones», con algunas consideraciones de trascendencia formativa y ascética y su valor de proyección social. Los primeros pasos en España hasta la inauguración de la casa propia en La Grania; terminándose con una amplia información bibliográfica. La presentación del Movimiento está hecha.

Por la unión con el anterior, aunque no de la colección misma, reseñamos a continuación el folleto del mismo autor El Movimiento del Mundo Mejor, que responde al deseo de dat a conocer la esencia del Mundo Mejor y su funcionamiento. El autor de estas páginas pronunció seis conferencias cuaresmales en el Instituto Nacional de Estadistica. En ellas expone detalladamente la llamada de 
Pio XII en pro de un Mundo Mejor; lets aspiraciones apostolicas del Mowmiento * los sectores de actuación deratro del freate católico en el mudo sector de la Verdad, de la Gracia, de la Caridad y de la Yusticia social. La 4 trma conferencia marca las caracteristicas de renovación, restauración y procedimientos apostólicos del Movimiento del Mundo Mejor.

Sacardotes y Seglares limita las exigencias del Moximiento para un Mundo Mejor a los sacerdotes y seglares dentro de li A. C. Y siguierndo la inspiración del nuevo Movimiento. Con ese espiritu de revisión tan caracteristico del M. M.y se enfrenta con 10 que no y lo que sí debe ser la $\mathrm{A}$. C. Ser̃alados los defectos que deben corregirse, entra decidido en la exposición de las condiciones necesarias para estar en forma y al dia: la A. C. aebe ser activa, eficiente, dinámica, con sentido de responsabilidad, con capacidad de acomodación, unidad interna y espiritu de colaboración. Tiene un interés especial la jlitina parte dedicada al Apostolado Sem glar a través de la Profesión: verdadera preocupación actual de moralistas, sim gutiendo a Pio XII, «que es quien ha puesto de astualidad el rema profesional ex. nuestros diasy.

Son conocidas las pastorales sociales de Mons. Casimiro Morcillo. El tema «Cristo en la fábrica» abarca las pastorales: Teología del Trabajo, Teología de la Empresa y Deontología del Empresario. Precedidas de la circunstancial ultima Santa Misión del Nervión. En ésta se delatan las lacras de nuestro catolicismo: demasiada exterioridad, demasiado individualismo, demasiada tradición inerte, demasiaca inmoralidad e injusticia; agrandadas con cuatro males de nuestro tiempo: la lujuria, el hambre de dinero, el af́n excesivo de bienestar, la ixjusticia social. Los otros trabajos son demasiado conocidos de nuestros lectores para pormenorizar su contenido y su valor. Uno de ellos leido en la Semana Social de Salamanca, hace un par de años. Es indudable que Mons. Morcillo ha contribúdo como pocos a sembrar la inquietud en el mundo empresarial con sus escritos, la realización de la gran Misión del Nervión, a lo largo del cual se desarrolla una potente industria. con concentración de miles de obreros, y la acción impulsada con su exhortación y ejemplo en la ciudad de Zaragoza.

Dejamos para el ultimo lugar, por hoy, el libro de Fernández de Castro, Del paternalismo a la justicia social. «Es posible - se dice en la presentación o propaganda del libro- que la lectura superficial de este Hibro lieve al ánimo de algún lector la idea de que es un libro demagógico, en el peor sentido de la palabra.s. Desde luego no es libro para ponerlo en manos de apasionados; tal yez ni de quienes carecen de formación. Con frecuencia hay que pararse obligados a torcer el gesto, a reflexionar, para penetrar en la idea del autor $y$ sacar adelante aun la forma. Sinceramente escrito, to hay duda; con valentía como nocas veces hemos visto, también. Y aun, en definitiya, constructivo. Sí, pero constructivo después de haber hecho retorcerse multitud de veces a quien, responsable, haya tenido a su vez la valentia de leerle; porque hay muchos «sin atreverse a mirar de frente problemas tan graves y tan urgentes... como los que en el libro se plantean, como se viven en la realidad. Pero, sinceramente, hay expresiones que hay que trabajar para poder defenderlas. No se impacienta el pueblo por vivir formas arcaicas, sino por los abusos de injusticias... que se pueden dar, y se darán, desgraciada mente, aun en formas nuevas. Esos «afanes de renovación de nuestro pueblo no indican que sean injustas en sí las estructuras anteriores. No puede darse confusionismo entre el becho de elevar económicamente a los necesitados y declarar injusto en si el modo del desarrollo económico actual. Se cotidena tajantemente, en nombre de la Iglesia, so pena de restitucion, a los patronos que no dan el salario 


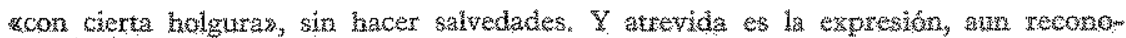
ciendo las lacras de nuestro catolicismo: usalvo en alganos casos; como determim nadas: wocaciones religiosas y excepciones al estilo del abate Pierre, la vida de los cristianos en nada se distingue de 1 a vida de los incredulos... \%.

Con habilidad, con interés y con originalidad, presenta la cuestión social de Espana, con los protagonistas de la misma, en sus dos manifestaciozies: La tensión bereficios-salarios y la tensión propietarios-ta propietarios. Fallos y wirkutes aprow vechables - sobre todo fallos, vicios de las clases conserwadoras; porque, an reconociendo que no hay que empezar desde cero, casi resulta la exigencia más abrunadora: derribarlo todo para empezar a construir wura cristiandad que no samos»-; el proyecto marxista de llamala al proletario y la revolución cristiana.

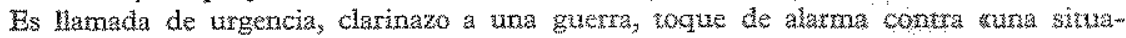
ciôn de injusticia».

Es un libro para dejarlo en manos de los responsables; de nha lectura sa sim lencio, alejada de enemigos a la vista para eviara la polémica pizede gue sa lectura haga de bisturi, de torcedor..., o sencillamente de incitador a tux seveno examen de conciencia.

No sabenos si hacemos bien dándolo a conocer en ana nota biblogratica sin ana disección detallada. Creemos que hemos dicho bastante, $y$ dejamos entrever no poco.

F. V.

ZUMALACÁRRegu, JOSÉ Maria de: Vilfredo Pareto. Madrid, 1951. Consejo Superior de Investigaciones Científicas, Inst. «Sancho de Moncada》 de Econornía. 189 págs., 22 cms.

El trabajo aparecido con el mismo título en la revista del Consejo Anales de Economia, numero 36 (octubre-diciembre 1949), consagrado como todo aquel número a la celebración centenaria del insigne profesor de Lausana, es el núcleo fundamental de esta obra, que se publica puesta al día merced a los datos conseguidos posteriormente. Entre éstos figura en primera línea la publicación en el mismo año centenario 1948 de la correspondencia de Pareto por su entranable amigo Guido Sensini: ciento noventa $\mathrm{y}$ un documentos (cartas y tarietas postales), que van desde noviembre del año 4 hasta julio del 23; todos, menos uno, autógrafos de Pareto. Documentos de $\tan$ excepcional importancia, dejan ver lo que él pensaba de su Curso de Economia, de la suplantación de éste por el posterior Manuale, de la economia matemática que cultivó en repetidas publicaciones y del plan, que tiene por superior a sus fuerzas, de publicar nuevamente su Cur- so en cinco tomos: uno de Sociologia, otro de Economía pura, un tercero de Economa matemática y dos de Economía aplicada con la colaboración del mismo Sensini.

Es de interés la trayectoria intelectual del ingeniero, político, conocedor profundo de la literatura clásica grecolatina, hasta hacerse el economista y profesor de economistas. Y una tez en el campo económico, su pensamiento, que perfeccionó el de su maestro walras, ha logrado en la posteridad un relevante puesto en mentalidades económicas tan insignes como la de Hicks, Allen, Wicksell, Stackelberg, Inving Fisher, Ragnar Frisch, Schultz y en entidades cual la London School of Economics and Political Scierce y la Econometric Society, según lo muestran sus respec tivas revistas Económica y Economém trica.

Finalmente, también entre nosotros la huella de Pareto ha quedado válidamente impresa no sólo a través de Stackelberg, sino aun directamente. Así lo reconoce el autor de este estudio, nuestro querido y no olvidado profesor don José María, quê en su estilo siz pretensiones se profesa afectuosamente discipulo presencial de aquel gran hom- 
bre, a quien tanto cree deber en su formación cientifica personal.

A. A. A.

GONZREA MORAZEJO, RAPAEZ: Bien co misn econónico y Distribución de la Renta Nacional, a la luz de lea Doctrina Maral y de la Ciencia Económica. Instituto Social León XIII. Madrid, 1956. 66 págs., 24 cris.

La formala minima de distribucion de la riqueza exigida por el bien conzín aperece en este discurso inaugural del año académico del Instituto León XIII como exigida también por la ciencia económica en orden a la elevación del nivel de vida de la sociedad. "Tal es la idea central, apoyada principalmente en la teoria de Keynes, quien requiere para el empleo de los factores de producción el estínulo e incremento de la demanda efectiva. Contra los que defienden la necesidad de producir más para poder llegar a distribuix, se opone la situación de los Estados Unidos del año 36 , en que el 40 por 100 de las familias se dice no lograban ingresos suficientes para la mera subsistencia. ¿Hasta cuándo, pues - se pregunta el autor-, va a ser necesario producir para dedicarnos de una vez a la distribución de lo producido?

Con simpatia se ve la posición, tan acertada como poco frecuente, del ecom nomista que defiende de manera tan franca la distribución. Digase lo mismo de la tendencia a aunar las conclusiones de la ética y las de la economía. Es lásm tima que la teoria de Keynes, en cambio, no sea tan aplicable a España en la presente coyuntura, como a un mundo deprimido por la crisis y el paro, que es propiamente la situación a que apuntaba la "Teoria general», que ha resultado no ser tan general en este sentido.

A. A.

Acción Soctal Patronal: La Libertad Económica en la Doctrina Pontificia. Madrid, 1955. 80 págs., $19 \mathrm{cms}$.

Recoge este folleto cincuenta textos pontificios, desde León XIII a Pio XII, en orden cronológico dentro de cada uro de los cuatro capítulos en que se bretende sistenatizat la materia, que son: El Orden Internacional; La Tnm tervención del Estado; La Propiedad y la Resporisabilidad Privada" y La Movilidad de los Bienes econónicos, Zmpleo y Migración.

Sin tratarse de ina coleccion exhaustiva, se logra la recta oriextación sobre problema de tarita actualidad, que es lo grese sto pretende.

Un indice pretio intenta sistematizar la doctrina ponaificia de cada capínulo: labor siempre arriesgada, si ha de permanecer totalmente fiel a los textos.

La ejecución laudable de esta iniciativa de Acción Social Patronal en otros asuntos análogos creemos contribuirá a la tan necesaria expansión de la doctrina pontificia en la vida social de los católicos.

\section{A. A.}

GEORGES FRIEDMANN: Ou wa le trawail humain? Gallimard, Paris; págs. 400.

Desde principio de siglo parece que la conciencia humana se siente inquieta por la actividad y las creaciones de la inteligencia, hasta llegar a cierta angusm tia y a una auto-acusación, exaltada por novelistas, moralistas y filosofos, que consideran el mundo moderno como un mecanismo absurdo e infrahumano. Este libro quiere responder a la pregunta de en qué grado las formas de trabajo sujetas a los progresos del maquinismo han contribuido a justificar esta acusam ción. Partiendo de la distinción fundamental entre el trabajo de las sociedades. premaquinistas y el trabajo técnico del siglo XX, el autor estudia la evolución de los oficios en las formas modernas. de producción y deduce de ello las tendencias en el inmediato porvenir, utilizando sus experiencias y observaciones recogidas en sus viajes al extranjero, sobre todo por Inglaterra, Bélgica, Suiza, Holanda y Estados Unidos. Pretende despertar la conciencia de los problemas humanos que se suscitan con el desarrollo de las técnicas, estableciendo que su dominio exige del hombre mom derno, si es que hay que restablecer el equilibrio, no un ssuplemento de alma», en el sentido del espiritualismo berg.- 
soniano, sino en todo caso un suplemeenco de fuerzas mowales.

La primera parte sitúa brevermente la oposicion entre el matio natural y el medio técnico y bosqueja ma teoria de la presencia hamana; este ensayo teorico se tlustra prácticamente con un documento de un escritor obreto, Jorge Nayel, notable por su autenticidad y variedad de experiencias. La segunda parte describe algunos aspectos de la técnica tal como los ha experimentado en un viaje a Estados Unidos. La tercera parte recoge algunos testimonios sobre el medio técrico que al autor le han parecido esenciales por sus impiicaciones y prolongaciones. La cuarta y blima parte hace derivar algumas tanm dencias del conjunto de las encuestas y se indican las posibilidades de una civilización en la que se armonizarian el progreso continuo de las técritcas en el trabajo productivo y el desarrollo del individuo.

\section{MARTIN BRUGAROLA}

JEAN DARIC: Viellissement de la population et prolongation de la vie active (Envejecimiento de la población y prolongación de la vida activa). Presses Uriversitaires de France, $\mathrm{Pa}$ rỉs; pågs. 208.

Entre los trabajos del Instituto Nacional de Estudios Demográficos figura éste sobre el exvejecimierzo de la población, que de todos los fenómenos som ciales contemporáneos es el mejor previsible y cargado de consecuencias, pero también muy ignorado, y que quizá ahora se quiera paliar por el aumento de la natalidad en estos últimos años precisamente en aquellas naciones más afectadias por su envejecimiento. Este trabajo tiene ante todo un fin de información. Se han reunido algunas indicaciones generales sobre el envejecimiento de la población francesa tal como se desprende de los datos demográfi$\cos$. Se examinan luego las consecuencias económicas y sociales, aun mal conocidas, de este fenómeno y se hace una rápida recensión de los medios aptos para combatirlas, entre los cuales se ha puesto la atención especial en la prom longación de la vida activa, 11 estudio se centra sobre esta solución y se aducen los resulsados de una amplia encuesta sobre las reacciones de la opinión publica en este punto. Con ello se ha constatado una zez más que el público estú mal informado en este dominio. Luego, después de indicarse las razotes que millyax en a de Ia vida activa en el estado actual de la situacion economica $y$ demogrática, se retrae una documentación estadistica sobre la participación de los trabajadores de edad avarzada en las actim vidades profesionales. Fhatmente, en una última parte se todican los princin pios generales que deberan presidir la realización de ana tal solución y se prem cisan las modalitades de aplicacion con referencia, siempre que es posible, a las experiencias francesas y extranieras.

\section{MARTHA BRUGAROLA}

BRIONES, Míximo: Mi empresa y $e$ t Señor. Una posible ayuda para el retorno de las masas al seno de la tiglesia. Madrid, Difusora del Libro, 1956: 160 págs. En rústica, 14 ptas.

Se dedica especialmente este librito. pulcramente editado, a dar a conocer una forma de apostolado ex las fábricas descrito por su autor en las siguientes palabras: "Consiste en una charla religiosa de media hota de duración, dada quincenalmente en el mismo lugar $\mathrm{y}$ a hora de trabajo... Ese dia los obreros trabajan siete horas y media y cobran ocho, y oyen con agrado al orador... También es muy importante el que después de la primera charla ruede metódicamente, sin avisos, sin preparativos. especiales».

Esta forma de apostolado, cuyas circunstancias y condiciones de exito describe por lo demás minuciosamente el libro, se hallaba implantada a la publicación de éste en 261 centros de trabajo, con excelentes resultados. En varios anejos el autor nos da la lista comapleta de las empresas, de la condición de los charlistas (sacerdotes, religiosos y seglares) y de diversac adaptaciones. a situaciones concretas. 
Tampoco se olvida el ator de resolm wer las objeciones que contra dicha forma de apostolado se katy presentado o pueden presentarse No se trata, indum dablemente, de una receta que valga para: todos los casos, pero, como escribe el: señor Obispo coadjutor de Badajoz, dor Eigeno Beiria, «aqui hablan los hechos. Las charlas religiosas se celebeari ya, con un resultado consolador, y por ese camino hay gue seguir adelante... \%. Los muchos prelatos que han bendeciclo la obra sori sin duda tam bién de la opinión de Mons. Beitia. No parece que pueda ser otra la ojinión de cualquier cristicino discreto por en cima de las prevenciones gue en nombre de derezminados principios suelen alegarse modernanente; siempre y cuando que ese apostolato de las fabricas se mantenga en los lámites y con las condiciones de éxito que el propio autor impone. No merece sino plácemes y aliento el señoz Briones por la iniciátiva y perseverante prosecución de esta obra de celo.

\section{M. M.}

\section{FRANÇors Bavdot: La coopération en}

France. Les Editions Ouvrières. Paris, 1956; págs. 102.

Un opúsculo actual que se refiere casi exclusivamente a la cooperación en Francia, y aun no a toda clase de cooperación, sino restringida a las cooperativas de producción, que en 1954 tenian 2.700 .000 socios, $\mathrm{y}$ a las coperativas de producción, que eran unas 600 en la misma fecha. Traza en primer lugar el cuadro económico y. social moderno en que tiene que desarrollarse el cooperativismo, la influencla que han tenido las doctrinas sobre el moviniento cooperativista, la historia de este movimiento en Francia, para pasar luego a explicar lo que es una economía de servicio la cooperacion, a la que Lasserre ha llamado «socialismo de la libertad». Finalmente, nos da motivos el autor del estado de la cooperación francesa en este sigto y nos explica su estructura y organización, sobre todo de los órganos centrales. Se termina con unas consideraciones sobre el porvenur de la cooperación.

M. $B$.
Les twitaillewrs migutants dans las pays insuffisamment déceloppes (Los tria bajatores whignantes en los passes insuficientenerze cesartallados), Bureat Intermational du Traval, Geneve 2 tomos 1953 1954; pags. 140 y 8.5 .

En estos dos vornos se aluce el informe de 1937 , sesion de la Conferencia Internacional del Trabajo sobre el tema. Se rraza una breve historia de la accion emprendida por esta organizacién en materia de migración, y luego se indica la neturaleza y lat anolitud de las migraciones de trabajadores y tas medidas tomadas para atenuar sus efectos en 36 páfes de Africa, Asyia, Amética latina $y$ en las Antillas. De 16 paim ses se da tambiér un informe sobre la situación de los-trabojadores migrantes en el sitio del empleo.

En el segundo tomo se copian las respuestas de los gobiernos al cuestionario mandado por dicha organización sobre este tema. Después de unas observaciones generales se sacan conclum siones sobre la forma de la reglamentación internacional, las definiciones $\mathrm{y}$ el campo de aplicación, la protección de los trabajadores migrantes $y$ de sus faw milias en su viaje $y$ antes y durante su periodo de empleo y sobre las medidas preventivas y limitación de las migraciones.

M. B.

\section{H. A. CrTrodk : Las Migrations Inter-} nationales. Librairie de Médicis, Paris; págs. 186.

Las migraciones internacionales son uno de los ejemplos más típicos del desorden creado en la vida de los hombres por legistaciones estrechamente nacionanalistas que se refieren, sin embargo, a un dominio esencialmente internacional. No es un libro de historia de las migraciones. Ya se han escrito extensos volúmenes sobre este tema. El autor se concentra en el estudio de los prom blemas econónicos y sociales suscitados por las migraciones modernas. Solamente expone histónicamente la inmigración en los principales paises modernos: Estados Unidos, Canadá, Argentina, Brasil, Israel; este trabajo está 
precedido por el estudio sintético de las causas de la eragración y sepúdo de sus écetos econónicos tos prises de inmigracion y en los pases de emigración. Otros aspectos que se estudian a continuacion son los sociales y los polím incos. La segunda parte cstá destinada al estubio de la politica restrictiva en materia de migraciones; el estudio, ream izzado bajo la direccion e irspiracion del conocido neoliberal Ropke, ya se puede uno imaginar que se opondrá a esta politica, de la cual marra sus origenes, som bre todo en los países anglosajones, y entre ellos el primero, Estados Unidos, y deshace sus argumentos, como el an mento de paro, la disminución det niyel de vida y de sialarios, la sobrapoblación se resturados de la inmigracion. Se señalar los efectos de la politica de las restricciones y se temina analizando lo poco que hasta ahora se ha hecho en el plano internacional para encauzar este importante problema, y raza el plan de lo que se podría llamar una politica internacional constructiva de las migraciones.

MARTAN BRUGAROLA $\$$. $\$$.

PaYAAN Y BELANGER: Syndicalisme et Coopération Agricoles. Presses Universituires. Laval; págs. 100.

La institución "Culture Populaire» de Laval ha publicado en este folleto dos ponencias referidas en el Congreso Mundial de la Vida Rural, de 1951. Una es de Mons. Pietro Pavan, secretario permanente de las Semanas Sociales de Ttalia; trata del sindicalismo agrario, de las causas por que se ha realizado lentamente, de sus aspectos múluiples y variedad de intereses, de sus objexivos económicos y profesionales y de algunas cuestiones sindicales generales con aplicaciones al sector agrario. Más extensa es la ponencia sobre la cooperación agricola del P. Gilles-M. Belanger, O. P.y del Consejo de Cooperación de Quebec y director de la revista Ensemble, órgano del movimiento cooperatito canadiense; la disertación sigue una marcha idéntica a la que sigue el mis- mo moximinato cooperativo en su efaboración: se busca smte todo definir la

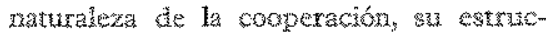
tura, funcionamiento y cutales son sus funciones economicas y sociales en el sector agrícola; luego se expond ba inregración y matuas relaciones del movit miento conperativo y cómo se extiende por stapas por las amensiones de un pais y varios paises, $y$ de que manera

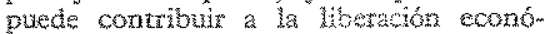
mica y a bienertar de las farritias agrícolas.

M, S.

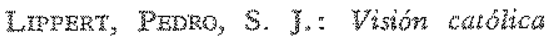
det mundo. T'taduccion por Lens MA-

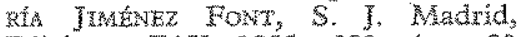
Ldiciones $\mathrm{FAX}_{3}$ 1955; 198 págs., 20 centimetros. Encuadernalo, 43 pras.

La idea inspiradora del Horo del $P$. Lippert es tan sencilla como Iuminosa: presentar a la mente del lector, de la manera más directa e intuitiva posible, y de un modo muy sintético, el conjunto orgánico de la doctrina cotólica. $\mathrm{Ni}$ mutilaciones ni ampliaciones; nada de escamoteos, nada de glosa, nada de comentario: sola y toda la verdad católica, en visión total, desde las cummbres, con la mayor simplicidad posible. Tal es al merito, tal as la dificil facilim dad del libro del P. Lippert, que sólo wn buen teólogo filosofo, posedor, por otra parte, de un estulo clato y conciso, ha podido escribir.

La obra se agrupa en tres partes: Contenido de la visión católica del mundo; Origen y desarrollo de la vision católica del mundo; Caracteristicas de la visión católica del mundo.

Hemos de agradecer tambien al $P$. Luis María Jiménez Font la exactioud y claridad de stu traducción, que resulta digne del original alemán. La imprem sión, vátida y esmerada. El libro ser leido con provecho por cualquier persona de mediana culruta, pero solo las más inteligerates e ilustradas advertirán toda 5 a belleza y cbtendrán el iruto que tha pretendido principalmente ol autor,

M. M. 


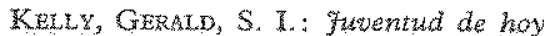
$y$ costidad. Traduc de Antorio Maria Martins, S. T. Segunda edición. Madrid, Ediciones FAX, 1956; 200 páginas. Eacuadernado, 40 pras.

Muy acertadamente observa al traductor del presente libro en su prólogo que, kdesgraciadamente, la mayorid, por no decir la totalidad, de los jovenes de nuestras ciudades conocen demasiado esm te asunto, y lo peor es que lo corocen a mediss, generalmente enfocado bajo el aspecto unilateral del placer, y desconociendo por completo el dedo de Dios en esta obra maravilosa de su creacionn.

Para dar a conocer precisamente ese dedo de Dios en esta su obra maestra de la creación es para lo gue se puede decir que va dirigido en primer luga este librito. Si hubiera aparecido en nuestra patria hace unos afios, cabria el decir que venía a llenar un wyacios en esta clase de literatura. Hoy ya no se puede decir esto, pero sí que ha de ser muy útil y muy apto para aclarar ideas, precisar conceptos, aquzilatar principios y tranquilizar conciencias; que no es poco, en verdad. No que digra, en absoluto, algo nuevo, inusitado o desconocido para los que se dedican y traran de estas materias; pero si que ha de ser mutry apto para aquellos que aún no tienen bien sentadas las ideas y que no se saben desentender de ciertas aprem ciaciones erróneas o principios deletéreos, que van informando la juventud algo irreflexiva e irresponsable en su formación y en la formación de sus conciencias. No tenemos, pues, más que alabanzas para el autor y el traductor del libro, hasta por su excelente prem sentación tipográfica. Pero permitasenos una insignificante observación general, no exclusiva de esta obra.

Who adolecerá un poco esta clase de literatura de morar más tiempo de 10 conveniente en la exposición de la parte, diríamos, negatiwa del vicio, matizando y como cromatizando muy por menudo su aspecto, negativo, no insistiendo tanto como fuera menester en la parte positiva? Un solo capitulo, y corto, nos ha parecido poco y flojo al prom pio tiempo, sobre todo comparándolo con todo el cuerpo del libro. Ponderar, quizá, más el valor de va virug a ta pureza, el mérito de la vizgridace consagrada a Dios, valonandola por las mismas ralabras de Jestus por San Mateo y San Marcos. Cierto; tho tolos entienden este punto, sino aquellos a gunenes ha sido dado.. Quien vueda erternder, extrendas, I esto mismo no pocas veces ha sido un acicate para amas grandes; alguna pocsación suscitada considerando extas $y$ otras palabra de Evangelio seria argumento del fruro que hacen las rectas exposiciones de las palabras divinas.

$Y$ precisamerte la juventud, por más ambiciosa en todo y aue todavía sueña en verificar en realidades los sublimes ensueños de grandeza a lo Javicx y Claver -ensueños dinámicos-, es la gute desea oí y leer esas palabres al ho de las otras. Ponderar el valor y la elo vación de corazón y de ideales gue supone la guarda de la virginidad nor amor de Dios; y precisamente por sar los menos; y precisamente por los valientes y esforzados; a esos ideales hy que mover los ánimos de los jóvenes de hoy. Cierto que es umelius nubere quam uri»; pero no es menos cierto que en valor $y$ en mériro supera la consagración de la virginidad y de la castidad a Dios y por su amor a todos los orros estados que no la suponen ni la necesitan. Ni hay que temer desalientos; que es muy humano y muy de los años primerizos en la vida sentir el aliciente de la admiración y del respeto; y para los valerosos y esforzados, los escogidos y privilegiados, basta que los mire Dos.

\section{V. $s$}

Puig, Igancio, S. I.: La Cueva de San Ignacio en Manresa. Barcelona, Revista Ibérica, 1953; 30 ptas.

\footnotetext{
- San Ignacio de Loyola y Barcelona. Barcelona, Revista Iberica, 1955; 155 págs.

- San Ignacio en Montserrat: La wela de las armas. Barcelona, Revista Ibérica, 1956; 143 págs.

El dinámico P. Ignacio Puig, director de la prestigiosa revista lbérica, se nos presenta en estos tres libritos o folletos
} 
en was de las mintiples tacetas que

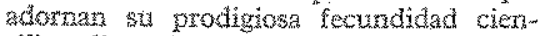
thica, literaria y ascentica.

Pero en esta qus Llamariamos tribgia ignaciana aparece, además del bijo fiel y amanie dy su padre y Fatrono, el enamorado de las verdaderas grandezas que inmortalizan los pueblos y gae han de ser al sarito orgullo de su patria chica, la fecunda region catalana; que no fanto se glorie de sus bellezas naturales y progresos industrales y éxizos taercantules cuanto por haber sido tegida por la Divina Providencia para la prem paración de la obra de la Compañu de Jestas en su pandador y Padre, San Igmacio de Loyola.

Si a Barcelona es la ciudad a quier mas debe, segin escribe al propio Santo, es Manresa su patria espiritual y es la Moreata de Montserrat quien, más como matre gue como reina, quedó prendada del corazon de su amante hijo y vasallo y voló, por decirlo ast, su cotazón materno en torrentes de gracias, a las cuales correspondio abundosamente Ignawio con su indestructible fidelidad y con la tenacidad propia de su carácter, de hiterro cantabro.

Bueź conocedor del paisaje el P. Puig $y$ de las costumbres $y$ de los lugares todos ane recorre, los muestra al lector como areolados y embellecidos: ila varita mágica de su cariño!

Interesantes resultan los tres por los datos que rénen $y$ por los antiguos monumentos y recuerdos gue aprisiom nan entre sus páginas. Para los turistas sirgularmente serviran los tres libritos de amables orientadores $y$ de guías experimentados.

Aungue pequefios en volumen y $\sin$ aparentes pretensiones cientificas, toca sin embargo el p. Puig todas las cuestiones $y$ entiende en todas las controversias y problemas suscitados desde el alborear de la Compañia y hasta el exceso exacerbados modemamente. $Y$ es muy natural que el P. Putig, después de enumerar los pareceres y hasta cierto punto valorarlos, se incline por lo admitudo cornúnmente por los Padres de la Compañía.

Les auguramos una grande difusión a estos tres libritos $y$ deseamos que su amena lectura sirva para ammertat el número de los vertaderos devotos de San Tgrincio y de los minadores de sus excolisas virudus.

\section{y. 3}

MARCox DE CoRre: Ensayo sobre el fin de nuestra civiluacion. Fomerito de Culura, viciones, Valencia, 1955 ; págs. 260 .

El axpor en wsia obxa acomete con acertados anahis sockologicos y de psicologia colectiva las tendencias de 1 a modera civilización. Hua moroduccion pstevia estudia to que puede constituir et eje y la esencia de una civilización.

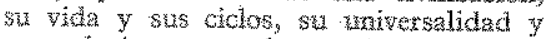
sus relaciones com la conciencia. Luego \&n cuatro capítulos los resultados det andilisis no son halagingros. Y un conflicto snte el espiritu $y$ la vida dirige 100 el proweso de cisolución de los valores en la civilización coxtemporånea, wna secuela importante gue se deriva de este mal que sufre el hombre mismo es la desviacion de la relación del hombre con St semejante, o sea, el conflicto entre lo politico y lo social, gue explica muchas tensiones y desproporciones que palpanzos entre estas dos categorias. A la luz de estos resultados se azaliza el cartícter técnico predominante de nuesura época y al colectivismo que resulta de ello. El cuarto analisis es el gue re sulta más desolador: se trazan las gram ves lineas del confficto que opone la civilización actual a la religión: las normas directrices de la civilizacion conremporánea, dea de progreso, técnicia e ideologia politica, mithan fodas las condiciones propicias al desenvolvimiento del ánima naturaliter cristiana o se oponen radicalmente al cristianismo; la simiente cristiana cae hoy sobre la piedra. El cristianismo burgués se vacia de su sustan. cia. El proceso de desvitalización se prosigue sin cesan $y$ es inhtil preguntarse to que serían los «valores》 y las «conguistas» modernas. En una amplia conchusión se estima que la suerte del cristianismo depende de una vuelta a less tradiciones sociales que se encuentran en el origen de todas las civilizaciones. La existencia de grupos relativamente restringidos $y$ que favorecen la presen- 
cia concreta del prójims, es indispensam ble al destrrollo del instino relagioso; farnilia, emoresa, profesión, parroguata, región, patria. En este proceso de revitafizactón el eiemplo de Teresa de Lisietur es alecciotador. La jeratquia de selecciones es también necesaria.

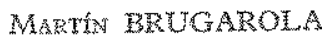

M. D. ChEsw: Pour una théologie du mavail (Para una reología del trabajo). Ediciones cu Setvil, Paris, 1955 ; páginas 124.

Conocido es el atuor por varias obras, entre las que descuella su obrita sobre la espirinualidad del trabajo. Del trabajo se ocupa la sociologia, la psicologia, has. ta tenemos una moral del trabajo y hace pocos años hasta una mistica del trabajo; pero son muchas las voces que dicen que aún no tenemos una teología del trabajo. El autor no pretende darzos una teología del trabajo; se contenta con desbrozar el camaino señalando los puntos en que fructuosamente se podría desarrollar esta teología acomodada a las exigencias de las nuevas características del trabajo, con el que se relaciona la técníca moderna, la concentración, el proletariado, la socialización, la civilización. Para fundar esta teología se impone una opción que se refiere a la conción sobre el hombre mismo, su relación con la naturaleza y su papel en la historia. No es lo mismo guiarse por Santo Tomás que guiarse por el augustinismo o el espiritualismo del siglo pasado, según el cual se continúa aún vim viendo. En el primer articulo de esta obrita se presentan las líneas generales de una teología homogénea, según el espiritu de los maestros cristianos del pensamiento griego y en la línea de la antropología de Santo Tomás. Se añaden dos artículos ya anteriormente publicados por el autor, en los cuales se señala el lazo indispensable que tiene una reflexión doctrinal sobre el trabajo con una teología de la historia, que se intitulan L'homo oeconomicus y el cristiono y $\mathrm{La}$ evolución social.

M. B.
GRORGES LEVARD: Chances et périts du syndicallsme chrétien. Bibliotineque Ecclesia. I Lbarate Artherne Fayard, Paris, 1955 ; págs. 223.

Se pretende en esta obra dar a conom cer el sindicalismo cristiano a través de la explicacion de las circunstancias en que nació, se organizó y crecíó la Confederación Francesa de Trabajadores Cristianos, de log esfuerzos que ha hecho para conservar su independencia y su carácter represeratativo y las dificultades cue ha tenido que yencer de parte de orros movimientos sindicates obreros y patronales. Se exponen adernás las condiciones en que el persarniento del sindicalismo cristiano se ha formado, despues de lo cual lógicamente se traza un analisis de sus cometidos y tareas actuales. El autor encontrará también nom ticias sobre la estructura del sindicalismo cristiano francés, sa expansión ent ultramar, sus relaciones con orgarismos internacionales, las razones del pluralismo sindical, la obra de sus congresos, su obra de formación, sus relacionse con la politica, sus planes en el orden ecom nómico y social.

M. B.

PIERRE MENDES-FRANCE et GaBruat ARDENT: La science économique et laction. Unesco-Julliard, París, 1954; páginas 230 .

La Unesco con este primer volumen, compuesto por el ex-presidente del Gobierno, comienza la publicación de la colección «Ciencia y Sociedad», que, en función de diversas disciplinas cientificas, examinará en qué xnedida las investigaciones cientificas proseguidas en los diferentes dominios de las ciencias sociales pueden llegar a resultados prácticos importantes. En este volumen se presentan la historia y los datos de la ciencia económica y se enuncia el problema de la elección entre un empirismo ciego y una orientación reflexiva, entre el paro y el progreso, entre la guerra y la paz. El problema de la elección se enuncia en los términos de cómo pueden los hombres, individual $y$ colectivamente considerados, sacar el mayor 
partido posible de los recursos limitados de aue âsponen, problema del equilibrio entre la oferta y la demanda, prom ducción y consuman, es jaro de los primeros que tenan que haberse planteado administradores y teóricos. Se estudia $1 a$ clásica teoria del equiliorio que race bajo la influencia de la burguesia gue al amparo de ales concepciones pretende acaparar el poder económico y politico. La descripción de los varios periodos de la politica economica hace que se aduzcan numerosos ejemplos sobre cl consumo y la inversión del capiral privado, paro, politica presupuestaria, evolución del conercio exterior, y sobte todo sobre la politica del pleno empleo, indacion $y$ dellacion, ahorro forzoso $y \mathrm{ra}$. cionamiento.

M. B.

\section{Trodoro Palacros CuETO y TORCuato \\ LuCa DE TENA: Embajadores en el infierno. Madrid, 1955; págs. 297.}

Las páginas de este libro están llenas de una autenticidad y de una emoción continua. Son las memorias del heroico Capitán Palacios, de la División Azul, que en la pluma periodistica $\mathrm{y}$ acertadísina de Luca de Tena nos narra sercilla y objetivamente sus once años de cautiverio en Rusia desde la batalla en que fué hecho prisionero hasta su desembarco en Barcelona desde el «Semíramis». En estas descripciones aparece la técnica de los campos soviéticos de concentración y de las cárceles soviéticas, el calvario de un dolor inmenso físico y moral que suscita la admiracićn $\mathrm{y}$ el silencio, el herósmo de unos hombres insobornables y fieles en todo momento a costa de indescriptibles sacrificios a la integridad del espiritu auténticamente español; la debilidad de no pocos y la traición de algunos. El libro no se deja de las manos y se termina con wn homenaje del corazón a este pur̃ado de hombres con el precio de tantos sufrimientos físicos y morales tan alta han dejado la fama del auténtico temperamento español.

A. B.
Traval forcé (Trabajo Lorzado). Eutales et Documents, vol. 36. Otganizacion Tnternacional del Trabajo; 650 pág.

En marzo de 1951 el Consejo Económ mico y Social rogó a la ongamización Internacional del Trabajo que colaborase en la creación de wna comision especial para estudiar el trabajo torzado en el mundo, tal como es aplicado como enderezamiento correctivo o como coerción politica o sarkcion respecto de personas caue posean o expresen ciertas ppiniones politicas, de modo que el desartollo de este trabajo forzado es tal que constituye hat elemento importante de la economía de uxa país dado. La comision juzgo que debra examinar los aspectos politicos y no woliticos del tra bajo farzado, y exarrinat los sistemas organizados de trabajo forzado, elegidos o adaptados deliberadamente por un Gor bierno como medios más o menos permanentes de orden político o económ mico o de los dos conjuntamente. Estos textos legislativos y reglamentarios y su aplicación debian ser examinados en función de la convención internacional del trabajo n. 29 sobre el trabajo forzado u obligatorio, en la carta de las $\mathrm{Na}-$ ciones respecto de los derechos del hombre $\mathrm{y}$ de las libertades fundamentales, como de la Declaracion universal de los derechos del hombre. La Comisión ha juzado que debía conocer las comtunica ciones y testimonios escritos ut orales de particulares y de organizaciones. Pero ha excluido ta esclavitud. Las condiciones de vida y trabajo de las poblaciones aborigenes, el trabajo en los establecimientos penales o penitenciarios, cuestiones curya competencia toca a orros organismos.

Todo una serie de patses no han hecho llegar comentaxios a observaciones en la fecha señalada que fué el 20 de mayo de 1953. Se encuentran entre vllos varios países de América del Sur y todos los paises comunistas. Las delagaciones de la U. R. S. S. y de Polonia cerca de las Naciones Unidas han devuelto los documentos no oficiales sobre la situacion ude hecho», pues uestos documentos contienen calumaias respecto de la U. R. S. S. (pág. 589), Lo mismo Polonia (pag. 352). 
No se puteden resumir todos thos informes $y$ respuestas de los gobierrios o de las deleguciones de écos en las Naciones Unictas. bu purto de partida y la norma de apreciación no parten de rna Lilosofia cuistana; pero ern la prácrica, el trabaio torzado ex las cordiciom rass previstas por la excuesta constituye un abuso de derecho namral y divino.

M. B.

Prate Pavan: L'ordine sociale. Earir. Mariet落, Turin, 1953; pags. 455.

Dl Instre Secretario de las Semanas Sociales de Italia y profesor de ciencias sacisles an la Universidad Gregoriana. divide esta $\$$ y obra exi tres partes: en la primera tra del mundo económico y on ella se examina el aspecto psicologico, moral, religioso, juridico y productivo de la actividad economica; la retribución del trabajo, el sentido y el valor de las leyes económicas, la solidaridad y colaboración a través de las formas del salariado, cooperación y contrato de sociedad; la intervención del Estado en el campo econónico y la colaboración mertakional en este mismo carmo.

fin la segunda parte se trata del movimiento sindical, de sus origenes históricos, del derecho a la asociación sindical, del criterio de organización, del principio de su acción, de su necesidad y fines, de las telaciones del sindicato con la corporación, el Estado, los partidos politicos, la religión y sus medios de acción, en especial la huelga.

En la tercera parte se exponen el lim beralismo y el marxismo; el primero en forma muy resumida, y más ampliamente el segundo, sobre todo por lo que toca al commismo ruso, en especial a base de las publicaciones de Stalin.

Aunque el libro se intitula El orden social, en verdad se examina este orden sólo en relación con el sector económico y sindical, por la razón de que esta obra está destinada al servicio de la formación de los sacerdotes en estas cuestiones. Se expone fielmente el pensamiento social cristiano sobre las materias que se van desartollando, con citas abundantes de los documentos sociales pontificios, wan dejar de atender a la realidad ectrómicomsocial tan cotriplefa y tam suleta rapidas evoluciones y aun acomodrado alguna disernacion a las fexi-

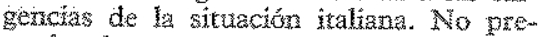
tarde el artor sar completo y wene la conciercia de que otos muchos temas se hubieran podido tratar muy oportunos y muy relactonados con el orden social, pero su obra es un šnstrumemo watioso mut orientador en el estudio de los remas thatamertales de la sociologia cristiand

\section{MARTIN BRUGAROL}

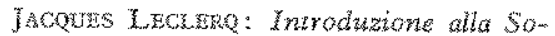
ciologia. Societa Edirice Vita \& Perisiexo, Mâan, 1954; págs. 234.

La palabra usociologian es joven, pues no tiene más de cien años, y fué inventada por Augusto Comte para indicar aquella ciencia que estudia la vida social como wn fenomeno natural. La sociologia ha encontrado no pocas dificultades para poderse constituir en ciencia eutónoma, $y$ aun hoy no todos estan de acuerdo ex el uso de esta palabra, ni siquiera entre los especialistas. Pero mientras los teorizantes discuten, la $\mathrm{som}$ ciología anda y se desartolla, oponiendo a la teoria el hecho innegable de su realidad. Por eso el mejor modo para acercarse a esta zueva ciencia es el nó todo desarrollaclo por el insigne publicista Leclerg en este volumen; se expone como ha nacido esta cicncia, on qué circunstancias se ha desarrollado $y$ en gué estado hoy se encuentra. Así van destilando los sociologos de varias naciones, la influencia que han ejercido sobre esta ciencia social, las obras gue han publicado, la formación de las diversas escuelas sociologicas y sus características y tendencias; no menos importante es determinar el objeto de la sociología y sus relaciones con la ciencia social, la filosofía social, la politice social, la psicología colectiva y la psicología social, la moral y la religión. Se traza también la división de la sociologín en general y especial, en estática y cinética. En otro capitulo se relaciona la sociología con la filosofía tradicional, ni menos interés ofrecen las observacio- 
Res del autor en relacion con la libertad. Finamente se determing lo gue ha de ser la saciologia y en qué manera las investigaciones saciológicas 8 constiturye una verdadera, erudita y solida intidiam ción en los problemas sociales.

\section{MARTIR BRUGAROLA}

GERALD WENYT: La energia nuclear $y$ su ustización para fines pacificos. UNESCO, París, 1955 ; págs. 78 .

El título de este folleto anuncia en compendio los principales aspectos de wh problema gue constituye ta preocupacion fundamental de 10 ONU $y$ de las instiruciones especializadas. Se defin ner las nociones generales y los térmí nos conthmente empleados cuando se habla de la energia atómica. Se presenta una explicación tertica de una explosión atónuca, y se enumeran los procesos que se operan en el seno de máquinas, reactores y trazadores. II folleto representa una preparación de los textos que sin duda entrarán a formar parte de la cultura que se dé en las escueles anuales escolares $y$ en los estudios científicos: carácter de los reactores, radioisótopos, residuos y subproductos de las combustiones y los acuerdos internacionales. Aparece la importancia de los radioisótopos y aplicación de la energía nuclear a la industria, a la agricultura y a la medicina. Las posibilidades de la energía nuclear son inconmensurables, y el día en que se hayan resuelto los problemas planteados, el hombre podrá disponer, a un coste minimo, potenciales extraordinarios.

M. B.

Grorges Spyroponlos: La liberté syndicale. Préface de Paul Durand. Librairie Générale de droit et de jurisprudence, París, 1956; págs. 391.

Natable tesis doctoral premiada de un estudiante griego en París. El autor ha emprendido el estudio sobre todo juridico de este problema de la libertad sin- dical, complejo, gue se coloca ex et centro de las preocumaciones de las sociedades contemporaneas, pero me entre.. tiene tambien en consideraciones de carácter sociológico, econótrico y político. Al que quisiese partir desde el punzo de vista de ur concepto organico de la vida profesional, quizas no estaría contorme con el metodo segudo por el autor, gue parte desde el punto de vista de la liberad sindical según lo ha crea do, de una manera atónica e individua1ista al Estado liberal. Así, partiendo de la libertad sindical cono et derecho absoluto a entrar 0 saltrse de cualquier sindicato, segúa le de ta gana al trabazador, se irán andizando todas las resm tricciones gue se van mopritedo a esta libertad asi entendiza, y por supuesto, no se llegara así a waya visićn orgánica de la organización profesional. Pero el autor parte de la realidad gue encuentra. en Francia, y la jurisprudencia y la legislación francesa que sobre todo lo que examina en los diversos problemas suscitados por la libertad sindical, que max́s bien es un haz de libertades. En este campo así limitado de la investigacióna e1 autor nos da un estadio completo del tema. Precede una introducción his htórica sobre el primcipio y la congutista de la libertad sindical, su consagración en Francia y en el orden internacional. La primera parte se destina al estudio de la libertad sindical en las relaciones de los sindicatos y del Estado, en que toca los siguientes puntos: independencia de los sindicatos respecto del Estado, al conflicto entre la autoridad del Estado y la acción sindical, la inzegración de los sindicatos en al Estado. La libertad sindical en el piano individual es el objeto de la segunda parte, libertad estudiada en sus dos aspectos: libertad de adhesión a un sindicato $y$ libertad de no adhesión a un sindicato. La tercera parte estudia la libertad sindical en el medio profesional: la libertad en las relaciones respectivas de los sindicatos; la libertad en el ejercicio del derecho sindical en el seno de la profesión y la libertad en el ejercicio del derecho sindical en el interior de la empresa.

MARTÍN BRUGAROLA, S. I. 
MARGaret DIGRY: The World Co-operatixe Movement (El movimiento coperativo mundial). Hutchinson's University Library, London; pági nas 163.

He aquí un precioso manual que explica perfectamexate el origen y desarroLo de todos los sectores del movimiento cooperativo mandial. Ea esta lectura el lector llega a zan conocimiento claro y sintético de cómo se ha producido el fexómeno cooperativo en el mundo. $Y$ aunque la obra se ciñe a la narraciba de la wida cooperativa y no pretende sistematizar los ptincipios cooperativos, no obstante, implicitamente de las pincelam das vitales que de las diversas clases de cooperación, se sacan fácilmente sus notas cariacterísticas.

Después de una introducción sobre a desarrollo y la historia de la idea cooperativista se comienza por explicar la cooperativa de consumo tal como nació en Inglaterra, para pasar a otras naciones, como comienza por Alemania al explicar las cooperativas de crédito agrícola y de crédito para artesanos y comerciantes. La misma información nos da sobre las cooperativas industriales, de suministros agricolas, de veruta de los productos de la ganadería, de los cereales y de los frutos, cooperativos maritimas $y$ forestales $y$, finalmente, las cooperativas de servicios. Un capítulo lo destina también al mutualismo, y otro a las granjas colectivas según el tipo ruso. Finalmente un capitulo se destina a explicar la integración cooperativa y oro a las relaciones de la cooperación con el Estado y la comunidad.

Martín BRUGAROLA, S. I.
Lezioni di cooperastone Corso teóricom práctico di preparazone cooperativiš nica. Istintuto Catudico di Attivitâ SOciale. Roma; págs 485

El Instituto Catolico de Acrividad Social, en colaboración con la Confederación Cooperativa Italiana, ha publicado la undécima edicion de este curso de preparación térico-práctico cooperativista con la participación de varios antores, a cuyo cuidado ha cortido la redaccion de sus distintas partes: historia y doctrina de la cooperacion; su organización y ordenación técnica; su administración y contabilidad; su régimen juridico y tributatio. Aunque muchos conceptos y exposiciones se refieren a la situación y legislación italiana, no deja He ser interesante la obra para el mom vimiento cooperativo españiol, dada la semejanza de caracteristicas con que se manifiestan en todas partes las diversas ramas de la cooperación.

El movimiento cooperativo, para ser digno de este nombre, exige una seria preparación moral, técnica y social de los socios cooperadores, de los elementos activos $\mathrm{y}$ dirigentes de la cooperación. Una seria preparación requiere, además del esfuerzo de responsabilidad de las personas interesadas, una guia suficientemente analítica y sintética a la vez, que facilite el estudio, la conciencia y la yam loración de los problemas de principio y de los problemas concretos de la ordenación técrica, administrativa y jurídica de las cooperativas. A estas exigencias responde el presente volumen, que recoge un curso de cooperación por correspondencia que organizó dicha institución con la colaboración de peritos en la materia.

MARTSA BRUGAROLA 


\section{mundo social}

Año IIt, tom. IIl, H. 24 Febrero 1957

IS⿴囗十)

Derroche de dinero

ORIENT MONONS

Repercusinges de una crisis.
J. Goenaga, J.

Miston providenctat de los potro. nos. Jutio I. Ventiz.

MNORMACIONES

Inglaterta por dentro.

E. Wuxtes. S.

PUNTO DE ESTUDIO

Correctinos al contrato de irabajo.

A. de O., 5. J.

Al Filo de la hoz.

Pazil M. Mlac Closkez.

Prascoplo SOCAL.

España: Movimiento denográfico. Hermandad de matrimonios catón. licos. Lat primera Universidad Lat boral femenina, Africk del Sur: El problema racial.-.- Alemania: Untión sindical cristiand ..... Austran tha: Servicio de reeducación $y$ de readaptación profesional.-.-Bélgica: Ahorro prenupcial. La Izquierda socialista se reagrupa.--Bulgdria: El último obispo detenido.--Francia: Piden prensa católica libte y caritarya.-Costo Rico. La patro na de Costa Rica coronada Rema del Trabajo-Hunsin: Patericos monsajes de los fóvenes deportam dos a Rusia. Mujeres húngaras prefieren morir autes gue ser escla vas. Se esperan inportantes acontecimatentos políticos. Restablecida la religión en las escuelas. Janos Kadar en conflicto con los obre ros. Una llamada de las mujeres de Mungtia. - talial en favor de las familas numerosas. Pais de Gales: Un nuevo convento - Po lonta: El acuerdo de Varsovia pro. mete gatrantas para la Iglesia....... U.R. S. S.: También los obreror rusos están cansados del Comunis. mo. Vietnam: Un sindicato mo delo.

DOCUNIANTOS

Kruscher cuenta los aimertes de $3 t 21 \mathrm{~m}$

REVISTAS

L1BRos

\section{BANCO CENTRAL}

Alcalá, 49 y Barquillo, 2 y 4 MADRID

t.

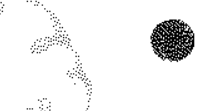

Ofind Centrat 295 Sucursa. Les y 77 Kencias en Capitales y principales plazas de la Pen insula, Islas Baleares, Canarias y Marmecos

Capital en circulacion:

350.000 .000 de ptas.

Fondos de reserva:

550.000000 de ptas.

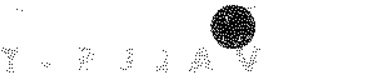

CORRESPONSALES EN TO.

DAS LAS PLAZAS IMPORTANTES DE ESPANA Y

DEL EXTRANJERO

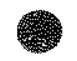

Autorizado por la Direccion Ge. neral de Banca Y Balsa con el riu mero 1.821 


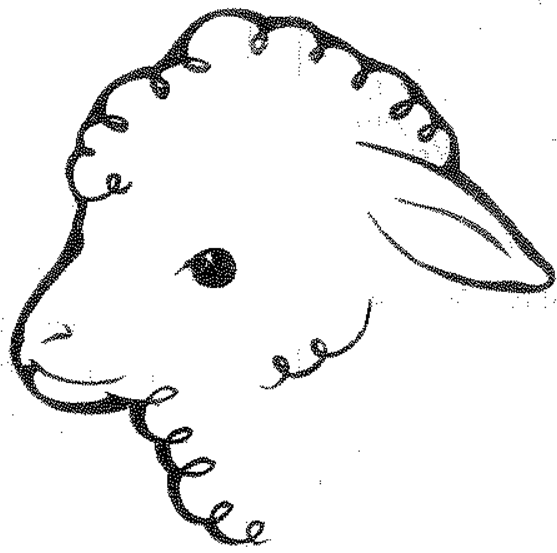

FRANCISCO CLOLS

CURIIDOS IA VALS-TARACONA

AGENTE GENERA. DE VENTAS Y APODERADO E I I 5 V APARTADO 36- ELDA. ALICANTE-TEL. 186 


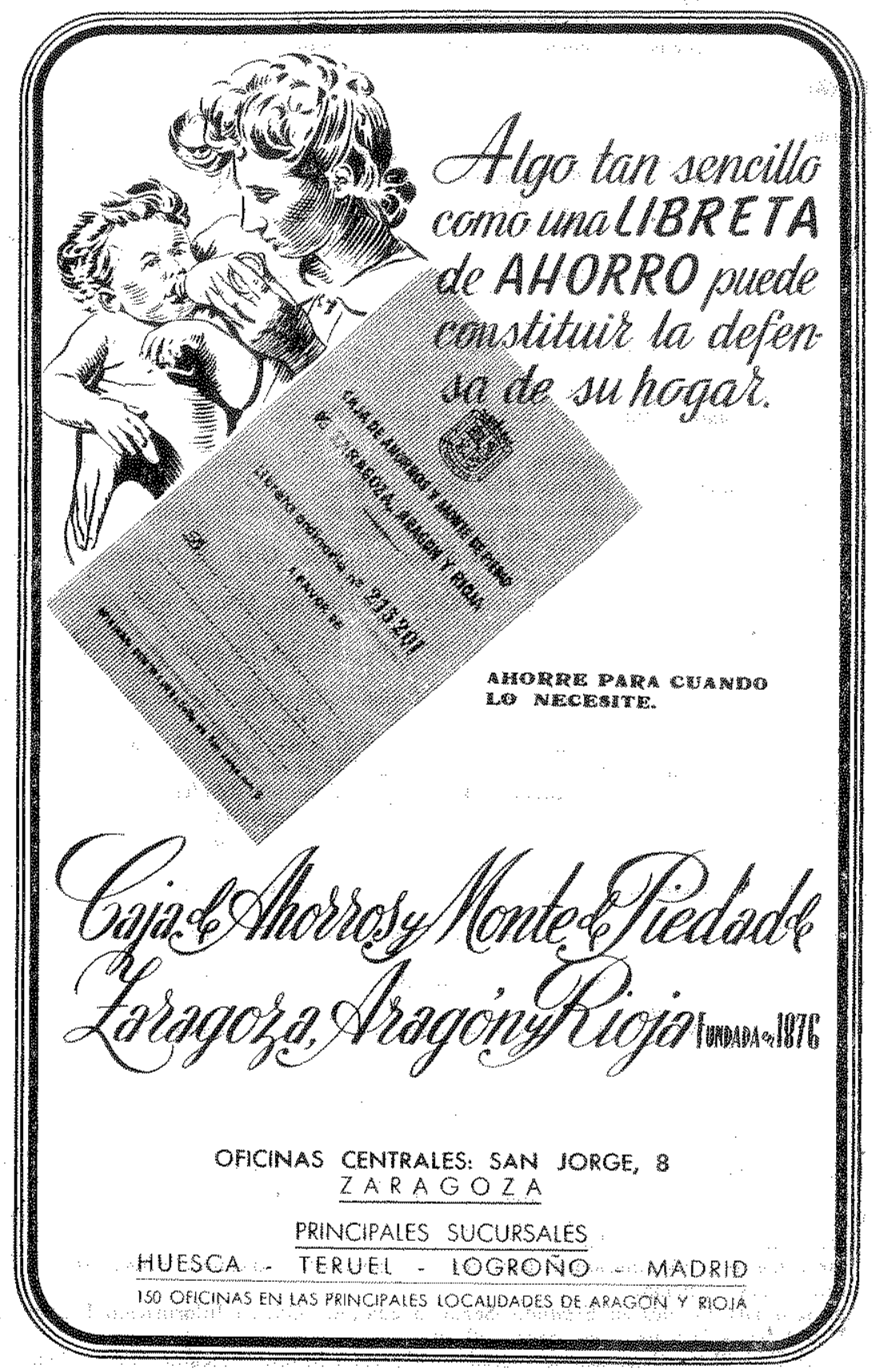




\section{BIBLIOTECA "FOMENTO SOCIAL"}

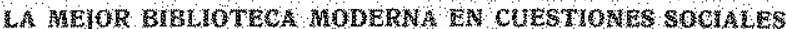

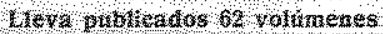

Qued a

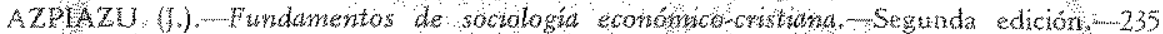

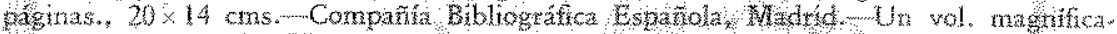
mente exculdernado, 75 ptas.

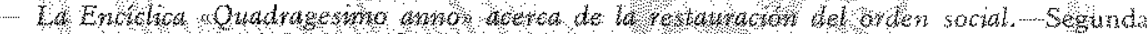

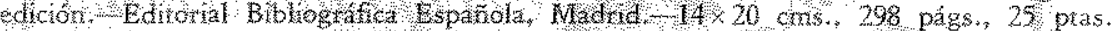

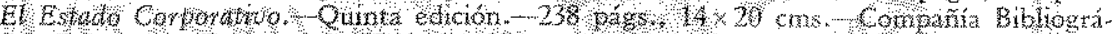

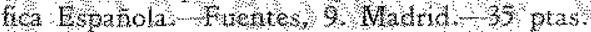

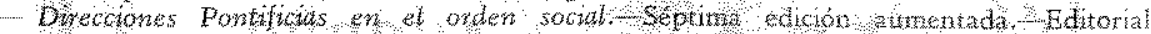

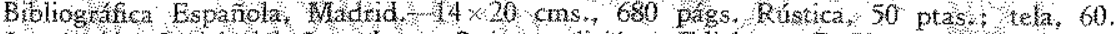

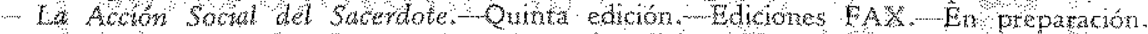

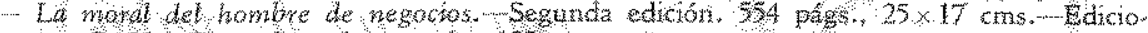
tos $\mathrm{FAX}$. Enetadernado en tal 18 ptas.

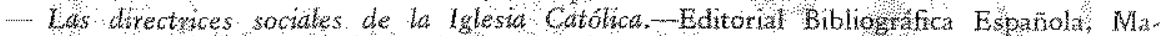
dro, 1950,131 pags, 15 ptas

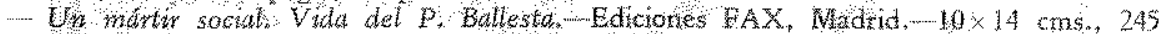
paimas, 15 ptas.

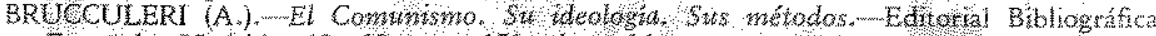
Española, Madrid, $13 \times 19$ cons 151 págs. 14 ptas.

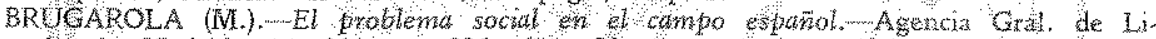
breria, Madrid - $16 \times 21$ ctrs. 296 pags. 30 ptas.

Socología criskiona del Dr. Tonas y Bages Agencia Grat de Libreria, Madrid.-. $16 \times 22$ cms., 339 págs. 20 pras.

Régimen Sindical Cristuno, Agencia Gral. de Libreria Madrd. $16 \times 20$ cms. 270 paginas: 25 ptas.

La ondenacrón social de las empresas $-256 \mathrm{gdgs}, 14 \times 20 \mathrm{cms}-\mathrm{C}$. B. E Fuentes, 9 Madrid -35 ptas.

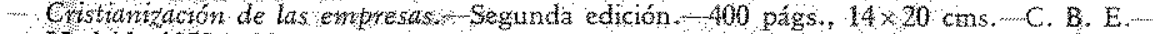
Madrid, $1952,-38$ ptas.

- Doctrind y sistemática sindical 380 págs. $14 \times 20 \mathrm{cms}-\mathrm{C}$ B $\mathrm{E}$ - 40 ptas.

Ta rewoluchón yerde Ed. Sapientia - 160 págs. 18 ptas.

- Soctologí nual cutólica. Companta Biblográfica Española Madrid.

CARDYN (J.). Los joveries obrevos ante el matrmonio.-Segunda edición. Traducción y

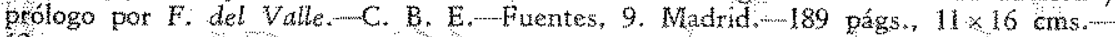
12 plas.

DIEZ (J. L. -Los Gremos en la España Imperial. El Mensajezo del Corazón de lesús, Bibao $-13 \times 19$ ctrs. 332 págs. 8 ptas.

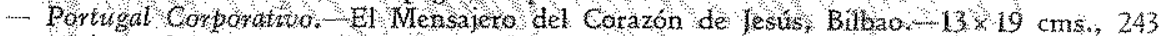
paginas, 8 ptas.

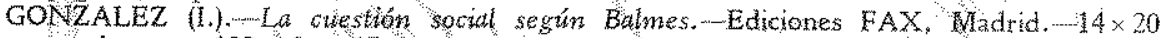
centímetros, 199 pas 15 ptas.

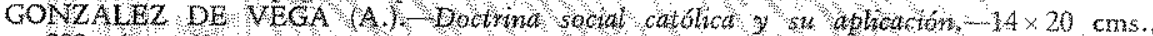
292 págs. 40 ptas.

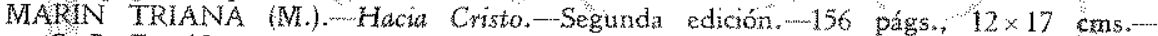
C. B. E.-12 ptas.

PABLO (Basilio de San)..mestudiemos a Cristo. Jesucristo en la wada y en la sociedad. El Mensajero del Corazón de Jesús, Bibao $12 \times 18$ cms 239 págs. 7 ptas.

SOLER DE MORELL (V) Rirdndo $a$ Cristo Considentones ascético-sociales. Ter. cera edición.-Ediciones FAX, Madrid. $14 \times 20$ crs., 243 págs. 18 ptas.

VALLE (F. del).-El $P$. Vicent, S. l., y la Acción Social Catolica Española-.-Editorial Bbliográfica Española, Madrid $-14 \times 20$ cnas, 362 págs. 30 pas.

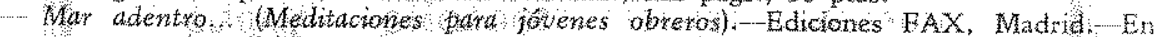
prensa nueva edicion:

- Lás reformas socules en Espana.-Segunda edición.-Ofana Información Diplonática. Madrd. $-17 \times 24$ crs. 144 págs 30 ptas.

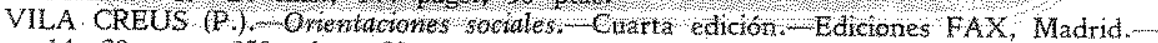
$14 \times 20$ cms., 350 págs., 39 ptas.

Estas obras pueden adquirirse en FOMENTO SOCIAL, Pablo Aranda, 3.MADRH 


\section{B I B L IOTECA \\ "Tomento Social"}

(NUEVAS PUBLICACIONES)

\section{Diccionario de Textes Sociales Pontificios}

por AnGBiz TOKRES CAMO

Yefe de Sección del Instituto Social do ta Nariza. Abogasio del Ilusatre Co legio de Madrid.

Asesor de WOMENTO SOCIAL

Uno obra sin precedentes ex la bi bliografía social cristian.

Más de 280 documentos sociales, de León XII a Pho Xll, concordados po materias y agrupados allabétcamente formando un volumen de más de 1.200 páginas, de facilisirta consulta y uso Cerea de 400 articulos y referencia

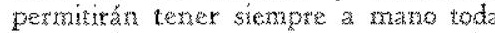
la doctrima acered de un punto de tertuinado.

In indice cronológico de documento utifixados (hasta julio de 1955) facilita la localización en el Diccionario de ur discurso, alocución o encíclica deter. minados.

Es un instrumento de trabajo insust tuíble, que pone en sat mano, en cual quier momento, el texto que prectse para el trabajo que le ocupe.

Un lujoso volumen de $22 \times 14 \mathrm{~cm}$ formado por 1.205 págs. en pape biblia. Enctadernado en tela con so brecubierta. Precio: 250 pesetas.

\section{Una vez sembré la verdad por ALARAZ,}

Saludamos este libro, que viene a po ner al alcance de la juyentud traba jadora, cada vez más exigente de ver dad y justicia, uno de los grande aspectos de la doctrina católica,

El libro es muy complejo. Ambientad un poro novelísticanente, deriya po Ia preocupación de los personajes gu intervienen hacia temas sociales, hon dos y apasionantes.

Pedidos a

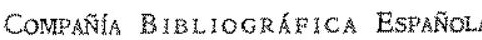
Fuentes, 9 


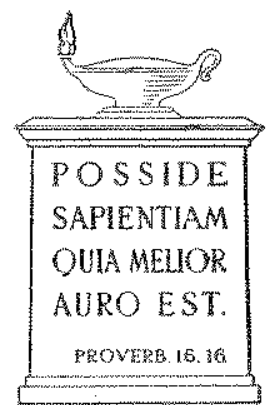

PRECIO: 24 PTAS. 